\title{
Studies of Longitudinal
}

Stream Profiles in

Virginia and

\section{Maryland}

By JOHN T. HACK

SHORTER CONTRIBUTIONS TO GENERAL GEOLOGY

GEOLOGIGAL SURVEY PROFESSIONAL PAPER 294-B

Preliminary results of a study of the form of small river valleys in relation to geology. Some factors controlling the longitudinal profiles of streams are described in quantitative terms

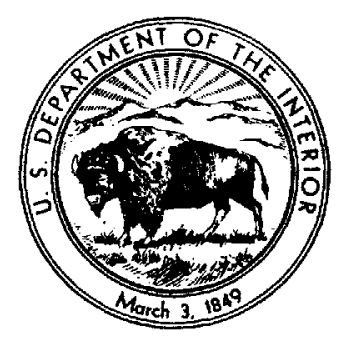




\section{UNITED STATES DEPARTMENT OF THE INTERIOR}

FRED A. SEATON, Secretary

\section{GEOLOGICAL SURVEY}

Thomas B. Nolan, Director

For sale by the Superintendent of Documents, U. S. Government Printing Office Washington 25, D. C. - Price 75 cents (paper cover) 


\section{CONTENTS}

Abstract.

Introduction.

Methods of study and definitions of factors measured

Description of areas studied.

Middle River bas

North River basin.

Alluvial terrace areas.....

Calfpasture River basin............

Tye River basin . . .

Gillis Falls. . . .

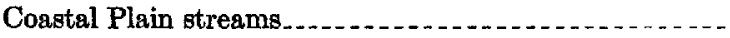

Factors determining the slope of the stream channel.

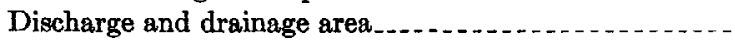

Size of material on the stream bed. .

Channel cross section

Summary of factors controlling channel slope........-

Factors determining the position of the channel in space: the shape of the long profile.

Relation of atream length to drainage area
Page

Relation of particle size of material on the bed to stream length.

Mathematical expression of the longitudinal profile and its relation to particle size of material on the bed....-

Mathematical expression in previous work on longitudinal profiles

Origin and composition of stream-bed material

Franks Mill reach of the Middle River..............

Eidson Creek.

East Dry Branch . . . . . . . . .

North River...

Calfpasture Valley.

Gillis Falls

Ephemeral streams in areas of residuum

Some factors controlling variations in size: conclusions . - . The longitudinal profile and the cycle of erosion References cited Index

\section{ILLUSTRATIONS}

\section{Page}

Plate 9. Drainage map of Calfpasture, North, and Middle river basins, Virginia............. In pocket

10. A, View of falls in Eidson Creek; B, view of

sandstone outerop in East Dry Branch__ Facing 80

FIGURe 8. Index map of parts of Maryland, Virginia, and West Virginia showing areas studied.

9. Plan and sections of hypothetical river valley showing quantities measured.

10. Plan of river bed showing grid layout.

11. Longitudinal profiles of principal streams in

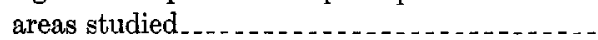

12. Drainage map of Nelson County, Va.........

13. Geologic sketch map of headwaters of the South Branch of the Patapsco River, Md.

14. Geologic sketch map of part of the Maryland Coastal Plain

15. Relation between drainage area and discharge in the Potomac River basin.

16. Relation between drainage area and slope at all localities.

17. Plan of short reach of Middle River above Franks Mill

18. Relation between slope and median size of bed material

19. Relation between slope and the ratio of particle size to drainage area

20. Relation of slope to particle size for streams in two groups having different drainage areas ... -

21. Three-component diagram showing general relations between slope, drainage area, and size, based on equation $2 \ldots \ldots$

22. Relation of drainage area to width and depth..

23. Relation of drainage area to depth-width ratio .--
24. Profiles of hypothetical streams showing effect of river length on profile............................

25. Relation of length to drainage area . . . . . .

26. Graph comparing measured and calculated values of stream length and drainage area in basin of Christians Creek ................

27. Relation of length to size of bed material. ... . -

28. Variations in size of material on the bed of Gillis

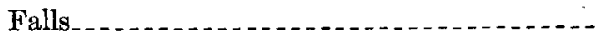

29. Relation of channel slope to stream length at all

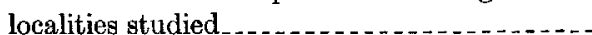

30. Graph of profile of Gillis Falls ..............

31. Graphs of the equation $S=k L^{n}$ for various values of $k$ and $n$.

32. Graph of the integrals of the function $x / L^{n}-2-1$

33. Relation of size of bed material to length in four streams . . . . . . . . . . . . . . .

34. Comparison of computed profiles with actual profiles.

35. Map of Middle River near Franks Mill showing changes in relative amounts of different types of rock in the stream bed.

36. Median particle sizes of lithologic components of bed material in Middle River near Franks Mill

37. Rate of decrease in size of sandstone component with distance of travel

38. Relations between distance of travel of three lithologic components and percent of the component in the bed load...............

39. Sketch map of Middle River at bed below Franks Mill. . of Middle River at bed below Frankg

40. Size and composition of bed material at locality 592 showing lateral changes................. 
Page

41. Relation of size of bed material to amount of

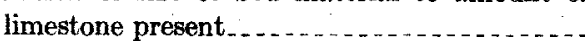

42. Sketch map and profile of lower Eidson Creek . - -

43. Longitudinal profile of East Dry Branch, and relation of reddish sandstone pebbles and boulders to reddish sandstone outcrops...........

44. Relation of channel slope to length of streams in areas of contrasting lithology

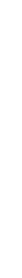

Page

45. Relation of slope to length typical of seven areas of different geology . . . . . . . . . . . . . .

46. Longitudinal profiles typical of four areas .....

47. Longitudinal profile of East Dry Branch and

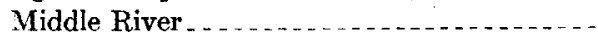

\section{TABLES}

TABLe 1. Measurements at locality 654, Calfpasture River, to show variations in size of bed material in a short reach

2. Values of the constants $j$ and $m$ for four streams . -

3. Comparison of profile equations computed from data on size of material on the bed, with profile equations computed from actual elevations in

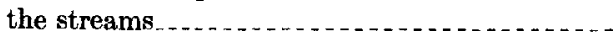

4. Parameters obtained by grid analyses, showing size and amount of boulders of tufa and lime-
Page

7. Particle-size and slope data in short streams whose channels contain fine-grained soil material.....

8. Principal measurements at selected localities.... .

stone in the accumulation downstream from the cliff of figure $38 \ldots$

5. Grid analyses of material on a talus slope on the east side of the Calfpasture River valley, locality 625.

6. Median size and amount (percent) of lithologic components of bed material at localities on Gillis Falls, Md 


\title{
SHORTER CONTRIBUTIONS TO GENERAL GEOLOGY
}

\section{STUDIES OF LONGITUDINAL STREAM PROFILES IN VIRGINIA AND MARYLAND}

\author{
By JoHN T. HAck
}

\section{ABSTRACT}

Streams in seven areas of Virginia and Maryland, in the Appalachian and adjoining Piedmont and Coastal Plain provinces, with different kinds of stream profiles and in geologically different terrane, were selected for study. In each of the areas measurements were made of stream length, drainage area, channel slope, channel cross section, and size of material on the stream bed. More than 100 localities were examined, on streams whose drainage areas range between 0.12 and 375 square miles. The measurements are compared on a series of scatter diagrams and relations among some of the variables that affect channel slope are discussed. The data for the streams studied indicate that the slope of a stream at a point on the channel is approximately proportional to the 0.6 power of a ratio obtained by dividing the median size of the material in the stream by the drainage area of the stream at the same point. This relation means that for a given drainage area the channel slope is directly proportional to a power function of the size of rock fragments on the bed, and for a given size of bed material the channel slope is inversely proportional to a power function of the drainage area. It is also shown that the ratio of depth to width decreases downstream in all streams studied. Streams in areas of softer rocks such as shale or phyllite tend to have deeper cross sections than streams in more resistant rocks, such as sandstone.

A very uniform relation between stream length and drainage area exists in all the streams studied, such that length (measured from a locality on the stream to the source along the longest channel above the locality) increases directly as the 0.6 power of the drainage area. This rate of increase is not affected, except locally and for short distances, by the geology of the basin. As a consequence of this relation and the one expressed above between slope, size of bed material, and drainage area, it is shown that for a given size of bed material, channel slope is inversely proportional to channel length.

The measurements of rock-fragment size made at all the localities indicate that variations in size are large. The average median size of the bed material ranges from a few millimeters in some streams to over 600 millimeters in streams on the east side of the Blue Ridge. In the latter streams many boulders are several meters in diameter. In some streams the size is the same, upstream and downstream. In others it increases in a downstream direction. In others it decreases downstream. Because for a given stream length the slope is roughly proportional to a function of rock-fragment or particle size, the differences in the longitudinal profiles from one area to another are related to differences in particle size along the channel. Differences in channel cross section probably also affect the profile, but this factor is not analyzed. It is shown that the profiles of some of the streams studied may be expressed by two simple equations. One, a logarithmic equation, applies where the particle size remains constant. This equation is

$$
H=k \log _{e} L+C
$$

where $H$ is the fall from the drainage divide, $L$ is the length from the drainage divide and $k$ and $C$ are constants. It is a straight line on semilogarithmic graph paper. The other equation applies where the particle size changes systematically in a downstream direction and has the general form

$$
H=\frac{k}{n+1} L^{(n+1)}+C, \text { when } n \text { does not equal }-1
$$

where $H$ is the fall from the drainage divide, $L$ is length and $k, n$, and $C$ are constants. When $C$ is zero this is a simple power equation and plots as a straight line on logarithmic graph paper. The two equations provide a wide variety of curves which are easily derived and offer a simple method of comparing many stream profiles.

Because the size of the bed material has been demonstrated to have an important effect on stream slopes and may show systematic changes along the stream, an attempt is made to analyze the factors that control the changes. Detailed size-distribution analyses, in which stream-bed samples were separated into lithologic components, were made in areas where the sources of the bed material are known. These studies show that coarse material enters the stream wherever the valley walls are steep and composed of bedrock. The size of bed material in a stream at any place is determined partly by the distance from such a source, partly by the initial size of the material, and partly by the relative resistance of the material to abrasion and breakage. The tendency of coarse boulders to form a lag concentrate near their source is an important factor related to the steep profiles in steep-walled valleys and gorges. The reduction of bedrock by chemical weathering and soil formation leads to gentle stream slopes and low divides between the headwater streams of some bedrock areas.

It is concluded that stream profiles are nicely adjusted to carry away the products of erosion of their basins, at rates determined by the initial relief, time, and the geology of the basins. Inasmuch as the longitudinal profiles are themselves indicative of the relief of an area and are intimately related to its topography, a geomorphological analysis of a region based on a comparison of long stream profiles is of value. Such an analysis, which is suggested but not developed here, may lead to modifications of some of our ideas on the development of land forms in the Central Appalachians. 


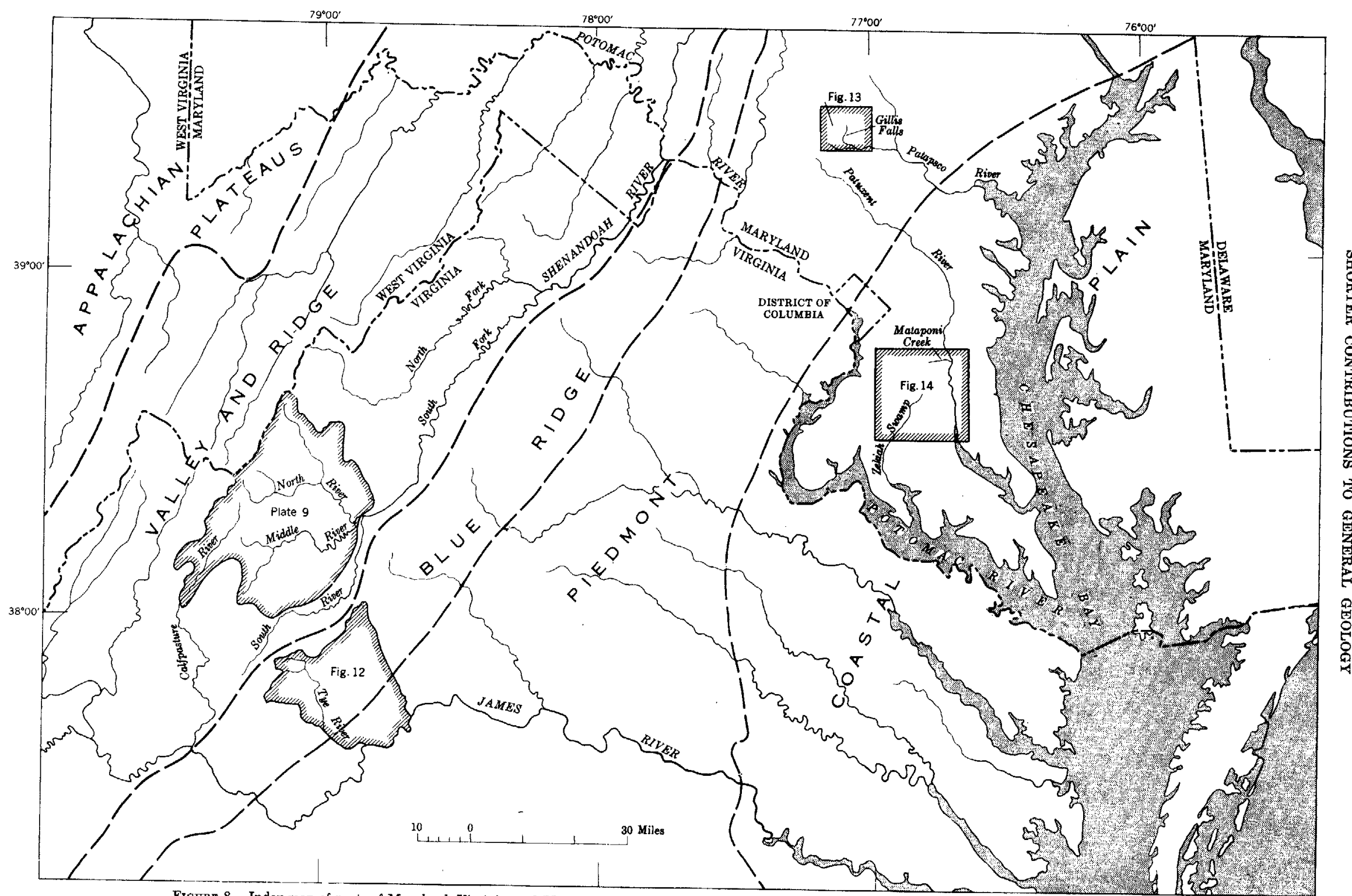

FiguRE 8.-Index map of parts of Maryland, Virginis, and West Virginia showing major physiographic divisions and location of rivers described in the report. 


\section{INTRODUCTION}

Studies of certain valleys in and near the Potomac River basin reveal that in this region streams in similar kinds of rock have similar profiles, and that they can be compared by a simple mathematical expression related to the conclusion of G. K. Gilbert (1877) that slope, or declivity; is inversely proportional to a function of discharge. Differences in profiles from one stream to another are found to be controlled in part by the particle size of the material on the stream bed. Particle size of bed material is partly a function of the rocks of the drainage basin, and partly a function of its physiographic history. The analysis and conclusions presented here are not intended to be comprehensive and are based on studies that are still continuing.

The objective of these studies, which are only partly reported here, is to analyze the development of land forms in relation to geologic history. The Potomac Basin and the region peripheral to it were selected because the bedrock geology is relatively well known, good maps are available, and there is considerable information on stream flow. The region embraces several major physiographic provinces that are subject to very different bedrock and soil conditions, including the Coastal Plain, the Piedmont, the Blue Ridge, and the Valley and Ridge provinces, and the Appalachian Plateaus (fig. 8).

Concurrent with these are studies of the petrology of soils and alluvial deposits by Dorothy Carroll (in preparation, 1957), which have been of value in furnishing quantitative information relating to the sources of material transported in gullies and streams. The writer is grateful to these investigators and to Paul Blackmon for suggestions and for assistance in obtaining data. L. M. Brush, Jr., L. B. Leopold, and M. G. Wolman have visited some of the areas studied and offered suggestions. R. S. Edmundson, R. S. Young, and members of the Virginia Geological Survey have aided in the identification of bedrock materials. Members of the U. S. Geological Survey, and particularly E. R. Mullen, formerly Director of the Technical Service, Veterans Administration, have given aid in the mathematical treatment of the data. Charles A. Ferriter, Jr., served as field assistant during the two field seasons, in 1952 and 1953 .

\section{METHODS OF STUDY AND DEFINITIONS OF FACTORS MEASURED}

Inasmuch as expressions for measurable elements of a river system are used throughout the report, it is desirable that they be explained at the outset. Measurements made at more than 100 localities constitute the data for analysis of the factors controlling stream profiles. Several standard measurements were made at each locality; the most important are listed in table 8 . The measurements described below relate to a single locality, or to a point on a stream channel.
Area.-The term area refers to the drainage area above the particular locality, including the drainage basin of the principal stream and of all the tributaries which enter it above the locality (fig. 9 and list of symbols, p. 49). In practice, area is measured on topographic maps, or in a few cases on aerial photographs, by use of a planimeter.

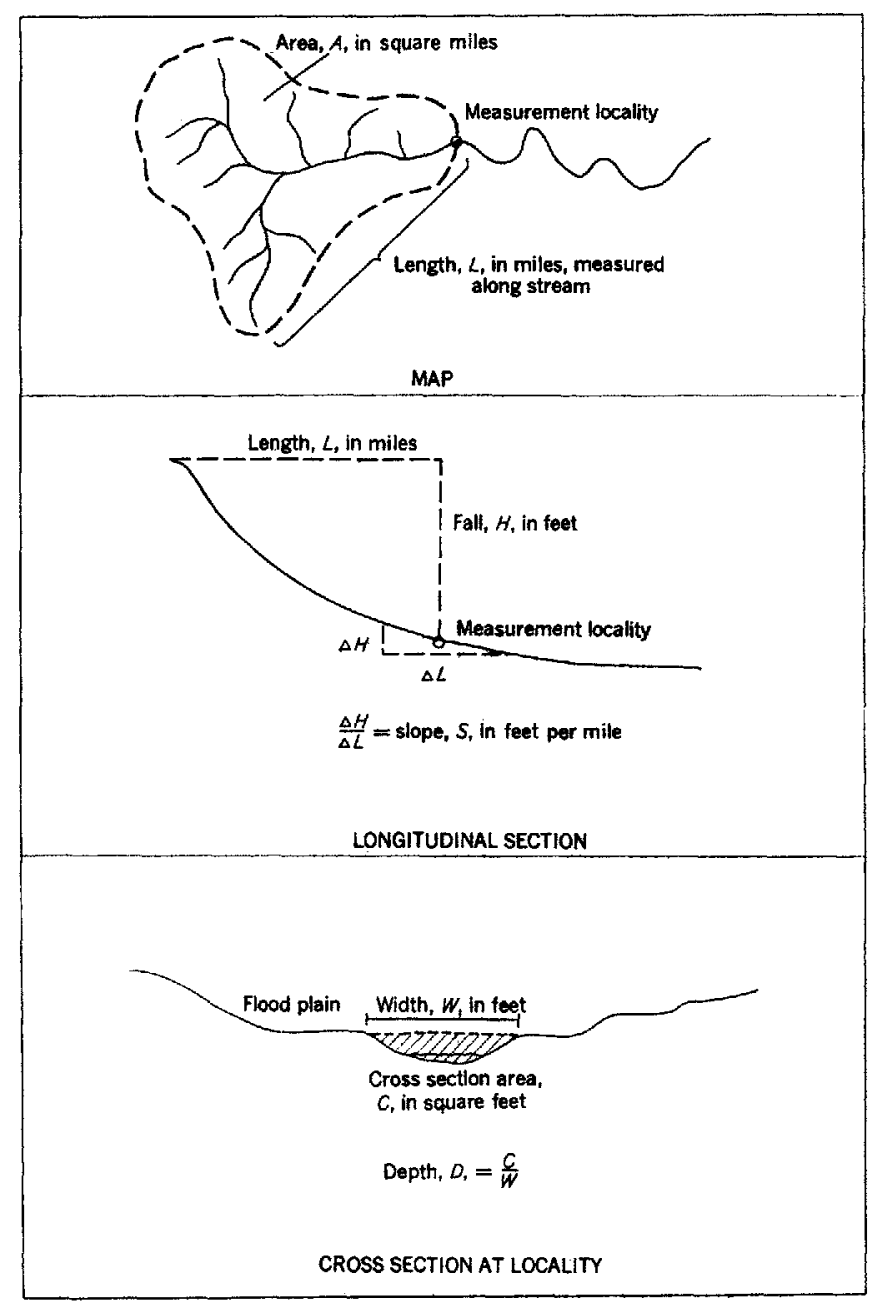

Fravre 9.-Plan, longitudinal section, and cross section of hypothetical river valley showing the measurements made at each of the localities studied.

As only two traverses are made with the planimeter at each locality, the measurement is not precise. Area is expressed in square miles.

Length.-The term length denotes the distance from a locality on a stream to the drainage divide at the head of the longest stream above it. The measurement is generally made on maps or aerial photographs with a map measure, along the stream channel and following meanders and bends; but in a few drainage basins it was made by tape traverse. Length is measured in miles.

Fall.-The fall is the vertical distance, or difference in altitude, between the locality and a point on the drainage 
divide at the source of the longest stream in the drainage basin above the locality. In other words, it is the vertical distance that the stream falls in the horizontal distance expressed by the term length. The fall is expressed in feet and is measured on maps simply by taking the difference between the nearest contour to the drainage divide, and the nearest contour to the locality. In some very small drainage basins fall was measured by traversing down the stream channel, reading increments of fall from a stadia rod with a hand level.

Slope. - The slope as used herein is the slope of a small reach of the stream channel at a locality, expressed in feet per mile. Measurement of slope is subject to considerable inaccuracy because of many local irregularities. Ideally, the measurement is the tangent to the longitudinal profile at a locality on the stream channel. Generally, the profile when measured in detail is not a smooth curve but is broken by pools and riffles. Near the foot of a pool the bed of the channel rises, and at low flow the surface of the water is very nearly horizontal.

Channel slopes were measured in the field over distances of 200 to 500 feet at every locality studied, using a 200foot tape and hand level. It was found, however, that the desired tangent to the profile could be better approximated by a map measurement. The measure finally adopted for use in the analysis is simply the vertical distance between the contour above the locality and the contour below the locality, in feet, divided by the horizontal distance along the channel between them, in miles. For very steep slopes the measurement includes several contours. As would be expected, the map measurements approximate the field measurements on steep slopes (over 100 feet per mile) but depart erratically from them on gentle slopes.

Channel cross section.-Measurements of the channel cross section were made at every locality. Like slope, this element is subject to many local irregularities. Presenting an additional difficulty is the fact that it is in many places impossible to determine what is the height of the flood plain above the stream, and whether or not a plain at one place represents the same surface as a similar plain at another place. The method used is rather time consuming and yields figures which are valid for one specific point on the channel but may not be typical of a whole reach near the point. A tape is stretched across the stream, from the edge of the flood plain adjacent to the channel to the edge of the opposite flood plain. Crosssectional area of the channel is measured by setting up a stadia rod at one end of the tape on the flood plain, and measuring the elevation of the stream bed with a hand level at intervals of 2 to 10 feet along the tape. The cross profile of the channel is plotted on graph paper, and the area measured. The width is defined as the distance be- tween the two edges of the flood plain. Depth is defined as the cross-sectional area divided by the width; in other words, the average depth.

Particle size of material on the bed. - In order to correlate slope with particle size of bed material, a sample of the bed material was obtained at every locality. This sample provided a distribution of sizes, which permitted calculation of the median diameter and other parameters. The method of sampling used is a variant of the microscopic method of measuring sediment size by counting grains on a rectangular grid; it has been discussed by Wolman (1954). A tape is stretched across the stream from bank to bank so that it hangs a short distance above the water surface. A clothes line to which 20 wooden bobbins are attached at 1-foot intervals is tied to the tape near one bank of the stream and floated on the water surface, as shown in figure 10. The operator walks along the line of bobbins

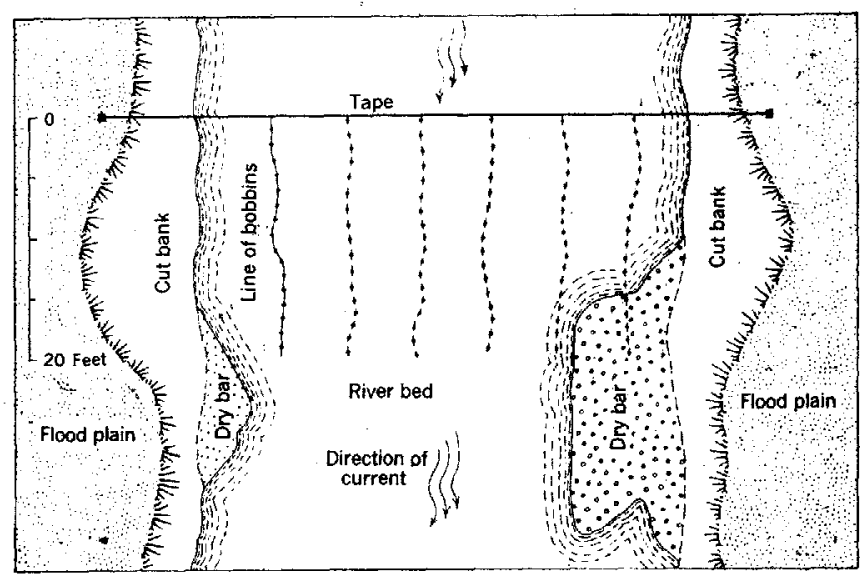

Frguan 10.-Plan of typical river cross section showing method of laying out grid for size-distribution analysis of material on stream bed. Dashed lines indicate successive positions of line of bobbins.

and successively picks up and classifies whatever material his finger first touches on the bottom directly beneath each bobbin. The classification is made with a meter rule divided into size-class intervals on a logarithmic scale. Only one axis of the boulder or pebble is measured, the intermediate axis. When 20 boulders, pebbles, or pinches of sand have been classified, the tape is moved a regular distance to another position, until grid points have been occupied over the entire stream width. An assistant keeps a tally, or tally is kept on a mechanical counter, such as is used in microscopic methods, mounted on the chest of the operator. As the method has already been described in detail and discussed elsewhere (Wolman, 1954) it is not discussed at length here. Although at first glance the technique may appear crude, it has in practice worked well for streams whose beds are composed dominantly of gravel and boulders. It has not at the time of writing been ap- 
plied satisfactorily in studies of streams that have sandy or silty beds.

The cumulative curves and parameters obtained by the grid sampling method represent the material on the surface of the bed, not the material beneath the surface. Nevertheless there is a close relation between the two. This relation has not been studied sufficiently to be thoroughly understood at the present time, but the material beneath the surface clearly contains more of the fine sizes than does the material on the surface. The grid sampling method is reasonably accurate. The error in estimating the median size can be reduced by increasing the number of rock fragments in the sample. In terms of well-known statistical principles, the accuracy of the method depends on the variation in the sizes of the fragments (which may be expressed as the standard deviation, coefficient of variation, or sorting) as well as the number of fragments in the sample. In other words, accuracy can be increased by increasing the number of fragments measured. In general, fewer particles need be measured if the variation of sizes in the deposit is small than if this variation is large. Wolman (1954) tested the method by making repeated counts of large numbers at several localities, and he estimates that for the kind of stream described herein, with counts of 100 grid points, accuracy is within 10 percent. In practice, the grids used have consisted of at least 100 points, and some have exceeded 500 .

\section{DESCRIPTION OF AREAS STUDIED}

The studies were made on about 15 streams, most of them in Augusta County, Va., in the area shown on plate 9. Studies were also made in the Blue Ridge (Nelson County, Va.), the Piedmont (Carroll County, Md.), and the Coastal Plain (Prince Georges and Charles Counties, Md.) (see fig. 8). The streams range from extremely steep mountain torrents, such as the Tye River, which have slopes over 500 feet per mile and boulders over 2 meters in diameter, to Coastal Plain streams, such as Zekiah Swamp, which have gentle slopes and carry fine gravel. Longitudinal profiles of the principal streams of the areas studied are shown in figure 11. All of the streams are down cutting; that is, their beds are close to bedrock and there are many outcrops in the channel.

Symbols. - Symbols used frequently in equations throughout the text are explained in the following reference list:

$A=$ Drainage area of the basin above a locality on a stream, in square miles.

$B=$ Altitude of a locality on a stream channel, in feet.

$C=$ Constant of integration used in equations describing stream profiles. Value of the constant determines the position of the profile in relation to the coordinates.

$D=$ Average depth of the stream channel, the quotient of the crosssectional area divided by the width, in feet.

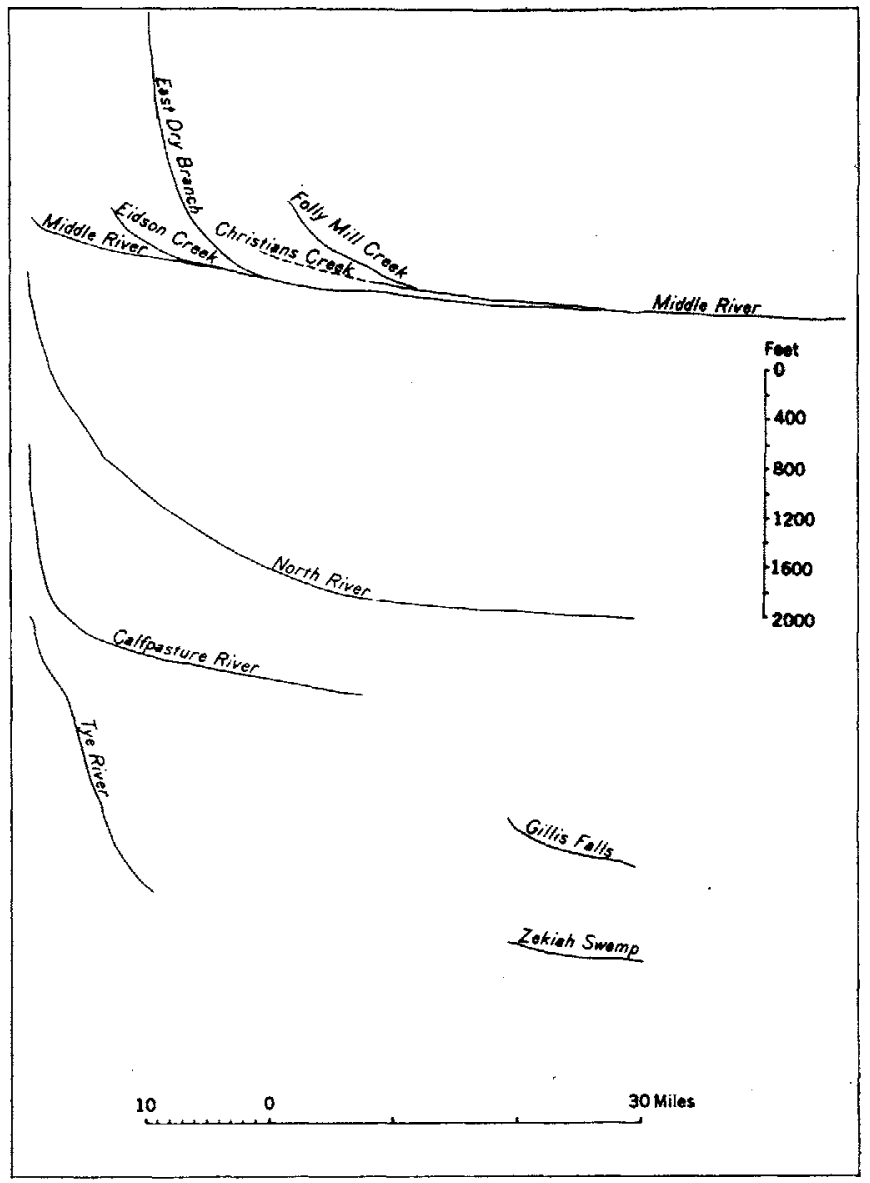

Figure 11.-Longitudinal profiles of the principal streams in the areas studier. All the profiles are drawn at the same scale. Length is measured from the lowest point on the drainage divide at the head of the prinoipal stream.

$H=$ Fall, the difference in altitude from the drainage divide to a locality on a stream, in feet.

$L=$ Length, measured from a locality on a stream to the drainage divide, along the channel of the longest stream above the locality, in miles.

$M=$ Median particle size of material on the stream bed, in millimeters.

$S=$ Slope of the stream channel at a locality, in feet per mile.

$W=$ Channel width, measured from one edge of the flood plain to the other, in feet.

$e=$ The base of natural logarithms.

$j=$ Constant of proportionality used in the equation relating median particle size to length of a stream; it represents median particle size of bed material at a river length of 1 mile.

$k=$ Constant of proportionality used in equation relating slope and length; it represents slope at a river length of 1 mile.

$m=$ Exponent used in equation relating median particle size to length of stream; it indicates the rate of change in particle size as length increases.

$n=$ Exponent used in equation relating slope and length; it indicates the rate of change of slope as length increases. 


\section{MIDDIF RIVER BASIN}

The Middle River, Va., and its tributaries have been the principal streams studied. They furnish conditions favorable to the investigation, because the drainage basin contains rocks which differ greatly lithologically, but which can be grouped into large, fairly homogeneous belts. The principal stream, the Middle River, has its source in the limestone region of the Shenandoah Valley at an altitude of about 1,900 to 2,000 feet, on the low drainage divide between the Shenandoah Valley and the James River valley. The Middle River meanders northeastward along the foot of Little North Mountain, the easternmost sandstone ridge of the Valley and Ridge province. It receives small tributaries that drain the sandstone area of Little North Mountain. At its junction with Buffalo Branch, the largest mountain tributary, the Middle River turns eastward and crosses a section of upturned limestone beds in a series of shallow but tortuous gorges, in places 200 feet deep. At Verona it crosses to the east side of the Shenandoah Valley, where it resumes its northeastward course parallel to the geologie structure, in a remarkable meander belt developed in the Martinsburg shale (Upper and Middle Ordovician). At its mouth, where it joins the North River, the Middle River has a drainage area of about 375 square miles, a total length of about 67 miles, and an average annual discharge of 298 cfs (cubic feet per second). The altitude at the mouth is 1,060 feet.

As shown on plate 9 , the largest part of the Middle River basin is underlain by limestone and dolomite. These rocks are mostly hard, cherty, and fairly uniform except for variation in the amount of silica. One exception is the Athens limestone of Ordovician age, which is a soft black noncherty limestone. It is marked in this area by a thin band of shale at the base. The Middle River probably follows this shale belt for a longer distance than any other belt in the limestone area. The average relief in the limestone area is about 300 feet.

The east side of the basin is mostly drained by Christians Creek, the largest tributary of the Middle River. It follows a wide belt of relatively nonresistant Martinsburg shale, a calcareous sandy shale which occurs in isoclinal folds that trend northeast. The shale belt has an average relief of only about 150 feet.

At the western edge of the basin, the limestones of the valley are thrust faulted over the Martinsburg shale along the foot of Great North Mountain. West of the fault, anticlines and synclines expose alternating belts of sandstone and shale of Silurian and Devonian age, which underlie a steep, mountainous terrain rising to altitudes higher than 4,000 feet. Four major tributaries of the Middle River-Buffalo Branch, East Dry Branch, Jennings Branch, and Moffett Creek - have their origins in these mountains on very steep gradients. They supply large quantities of sandstone gravel which composes the major part of the bed load of the Middle River as far as its mouth.

\section{NORTH RIVER BASIN}

The North River is somewhat larger than the Middle River, as its drainage area is about $\mathbf{4 0 0}$ square miles; but its length is less, only 42 miles. Its basin lies across the Shenandoah Valley, north of the Middle River basin, and contains similar bedrock and similar topography. The principal stream and the largest tributaries, however, head in large drainage basins in the mountainous area west of the Shenandoah Valley and supply much larger quantities of sandstone gravel than do the mountain tributaries of the Middle River. The mountainous areas contain a thick section of thin-bedded shales and massive sandstones, which range in age from Silurian to Mississippian.

The North River maintains a rather straight course across the limestone valley. For most of the distance it flows between wide sandy flood plains on steep gradients. Studies in the North River basin were confined to localities on the principal stream and on a number of steep tributaries in the sandstone area.

\section{ALLUVIAL TERRACF AREAS}

Several of the streams that drain the Devonian sandstone area west of the Shenandoah Valley emerge from the mountains into the limestone area in broad terraced plains, as indicated on plate 9 . In all these areas the stream valley widens sharply as it enters the limestone region. The flood plain and terraces flanking the stream widen in places from a belt a few tens or hundreds of feet wide to extensive plains a mile or more in width. Although the bedrock in these areas is generally limestone, the bed material, banks, and terraces of the streams are entirely of sand, gravel, and boulders transported from the sandstone area upstream.

The reaches of the through-flowing streams that lie within these areas have common characteristics very different from the streams outside them. Measurements were made in areas along East Dry Branch and the North River and are included in the data presented here.

\section{CALPPASTURE RIVER BASIN}

The Calfpasture River is a headwater stream of the James River, not of the Potomac River. It drains the first wide anticlinal valley west of Great North Mountain and is judged to be representative of many Appalachian streams that drain valleys eut in shale between high ridges of sandstone. The valley floor underlain by shale is veneered by well-developed flood-plain and terrace gravels, composed entirely of sandstone derived from the mountains on either side. 


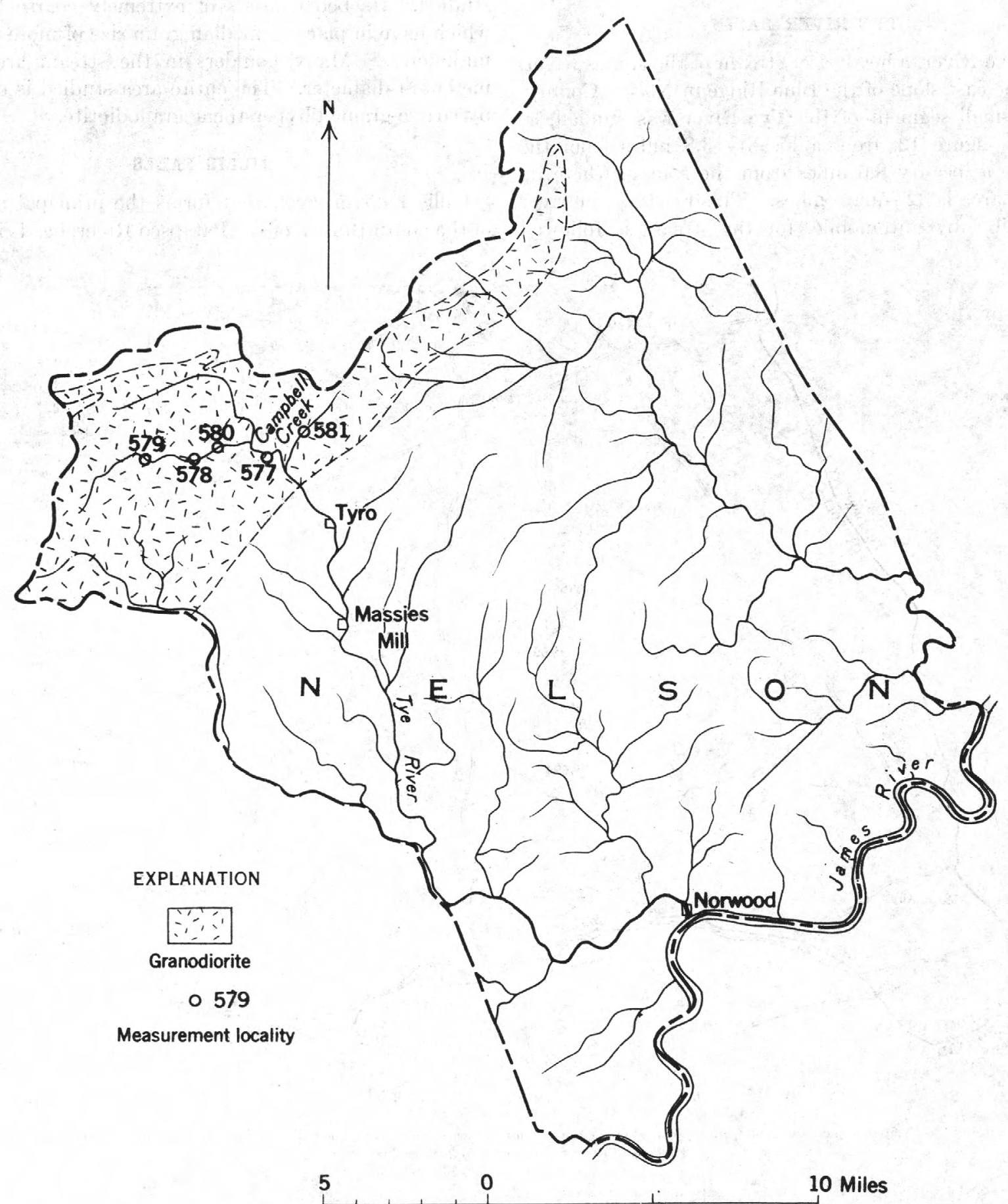

Figure 12.-Drainage map of Nelson County, Va., showing the area of granodiorite and the location of measurements in the Tye River basin. Granodiorite area from Geologic Map of Virginia (Va. Geol. Survey, 1928). 
The river channels are wide and shallow, dry in summer and fall or with pools of still water. But in winter and spring they run with swift, clear water.

\section{TYE RIVER BASIN}

The Tye River, a headwater stream of the James River, drains the east slope of the Blue Ridge in Nelson County, Va. A small segment of the Tye River was studied, as shown in figure 12, from a locality 3.8 miles from the source to a locality 8.6 miles from the source, where its drainage area is 32 square miles. This reach of the river is accessible by automobile, for the stream is followed closely by Virginia State Route 56 . The Tye River was selected for study because it flows on slopes that are remarkably steep as compared to those of the other rivers studied. Its bed consists of extremely coarse boulders, which have in places a median grain size of more than 500 millimeters. Many boulders in the stream are over 3 meters in diameter. The entire area studied is underlain by coarse-grained hypersthene granodiorite.

\section{GILLIS FALLS}

Gillis Falls, a creek that forms the principal tributary of the South Branch of the Patapsco River, heads in a high

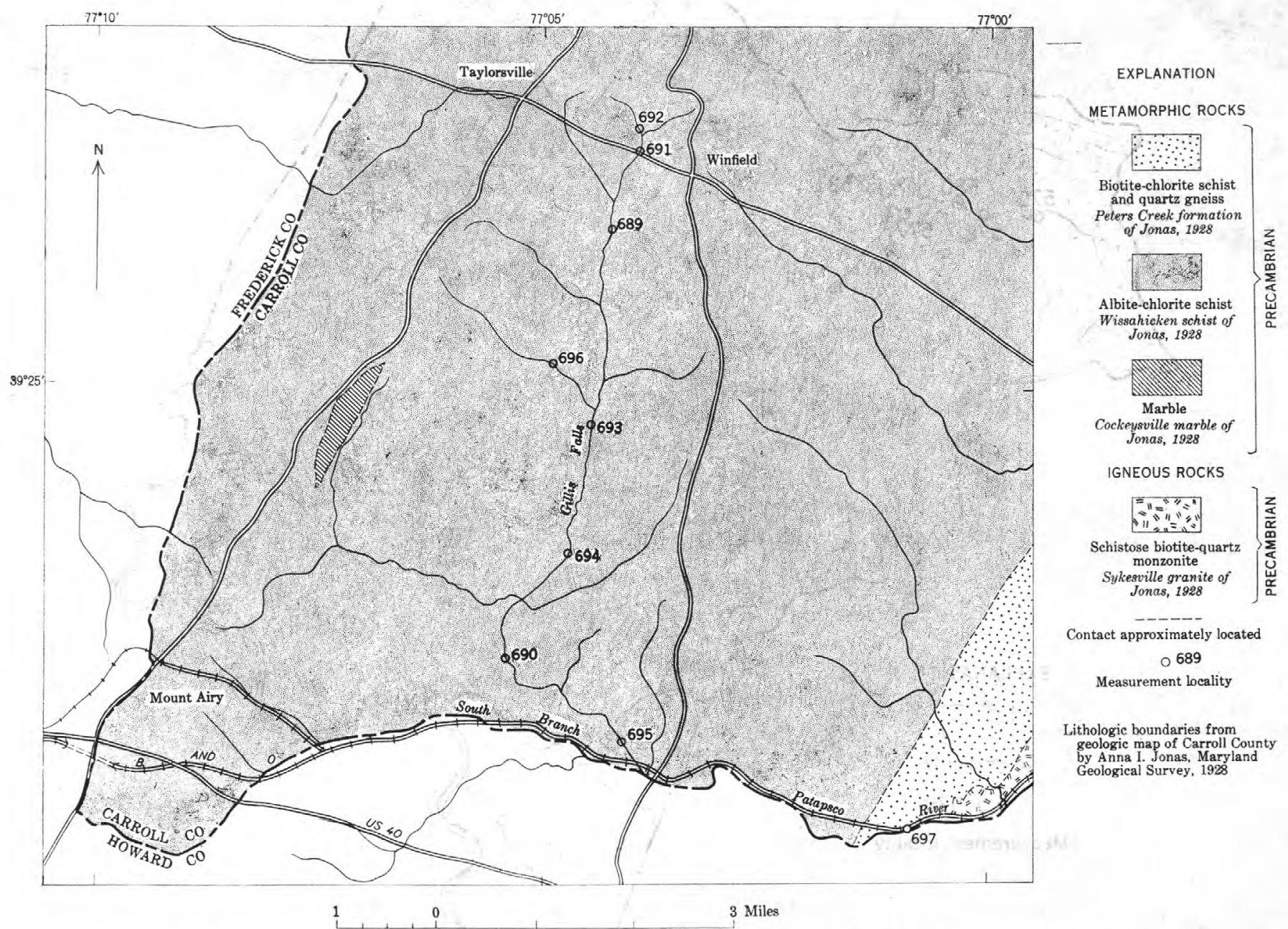

Figure 13.- Map of a part of Carroll County, Md., showing the location of measurements in Gillis Falls and the South Branch of the Patapseo River, and the distribution of major lithologic units. 
rolling area in Carroll County, Md., south of Westminster. This stream was chosen for study as an example of a Piedmont stream. Its drainage basin lies entirely in a belt of Wissahickon schist (Jonas, 1928), which here is darkcolored phyllite, cut by numerous veins of quartz. One locality was studied below Gillis Falls on the South Branch of the Patapsco River in an area of Peters Creek schist (Jonas, 1928). The drainage basin studied has an area of about 39 square miles and a length of 11.9 miles. In this distance the principal stream falls from an altitude of 880 feet to 440 feet. The small headwater valleys of Gillis Falls are open and gentle, with smooth slopes. At a short distance downstream, however, the river valley becomes gorgelike and, near its junction with the South Branch of the Patapsco River, takes on almost the character of a mountain stream. The locations of the measurements are shown in figure 13.

\section{COASTAL PLAIN STREAMS}

Several localities were visited in the Coastal Plain of Maryland as shown in figure 14 , in order to obtain examples

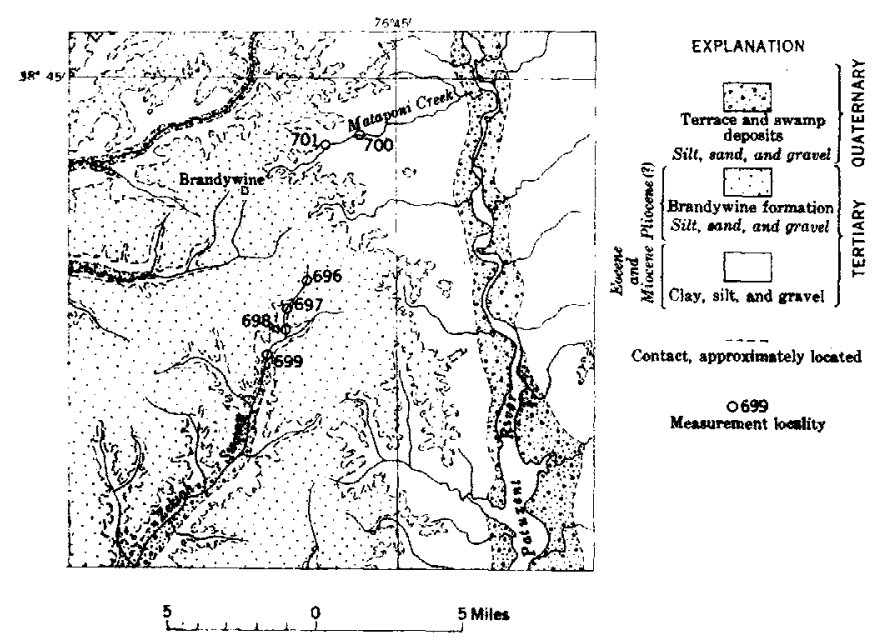

Froure 14.-Geologic sketch map of a part of the Coastal Plain of Maryland showing the location of measurements in the basins of Zekiah Swamp and Mataponi Creek. Geologic boundaries from U. S. Geological Survey Prof. Paper 267-A and unpublished data of J. T. Hack.

of streams in areas of low relief, markedly different geologically from the other areas studied. Measurements were made on tributaries of Zekiah Swamp, one of the main streams draining Charles County, Md., and also on Mataponi Creek, a short tributary of the Patuxent River in Prince Georges County. These streams head on the Brandywine formation, a gravelly deposit of Pliocene(?) age. For most of their courses they traverse unconsolidated sands and clays of Miocene age, but their beds and banks are composed of gravel and loam derived from the Brandywine formation.

\section{FACTORS DETERMINING THE SLOPE OF THE STREAM CHANNEL}

G. K. Gilbert stated as early as 1877 (p. 114) that declivity (or slope) is inversely proportional to quantity of water (discharge). Although some workers have followed Sternberg (see Woodford, 1951, p. 813) in the belief that the slope of the stream channel is related directly to the size of the bed load, it has been generally accepted since Gilbert's time that discharge is an important factor.

W. W. Rubey (1952, p. 132) has analyzed stream slopes using data obtained by Gilbert in an experimental flume (Gilbert, 1914). Rubey concludes that when the form ratio (or depth-width ratio) is constant; the graded slope decreases with decrease of load or particle size, or with increase in discharge. A stream may adjust, for example; to an increase in particle size either by an increase in depth (in relation to width) or by an increase in slope.

Rubey's conclusions are summarized by him in the f ormula:

$$
S_{G} X_{A}=K \frac{L^{b} D^{\mathrm{c}}}{Q^{e}}
$$

where

$$
\begin{aligned}
S_{G}= & \text { graded slope of a water surface measured after } \\
& \text { adjustment to load, discharge, and other con- } \\
& \text { trolling variables, } \\
X_{A}= & \text { optimum form ratio, the proportions of ad- } \\
& \text { justed cross section, or depth-width ratio, which } \\
& \text { gives to a stream its greatest capacity for trac- } \\
& \text { tion, } \\
L= & \text { the stream load, the quantity transported } \\
& \text { through any cross section in unit time, } \\
D= & \text { average diameter of particles that make up the } \\
& \text { load, } \\
Q= & \text { volume of water discharged through any cross } \\
& \text { section in unit time, }
\end{aligned}
$$

and $K, a, b, c, e=$ constants.

In this formula, the channel slope $S_{G}$ and the form ratio $X_{A}$ are dependent variables, either or both of which may be adjusted to the conditions of load and discharge imposed from upstream. The data presented in this report permit an appraisal of some of the factors discussed by Rubey, and a similar, though less comprehensive, conclusion is reached independently in the present analysis.

In this discussion it is assumed that the slopes of the streams studied are determined by conditions imposed from upstream. As stated by Rubey (1952, p. 134), "The slopes at different points and the shape of the profile are controlled by duties imposed from upstream, but the elevation at each point and the actual position of the profile are determined by the base level downstream." The 
measurements of the various factors studied are plotted on a series of seatter diagrams so that the relations among them can be assessed.

\section{DISCHARGE AND DRAINAGE AREA}

The quantity of water or discharge is one of the most important factors controlling slope but as a practical matter cannot be measured except where there are gaging stations that have been in operation for many years. There are only three of these on all the rivers studied for this report. One is on the Middle River a few miles above its mouth, and two are on the North River. However, a conservative relation exists in this region between drainage area and discharge; that is, enlargement of drainage area is accompanied by proportional increase in discharge.

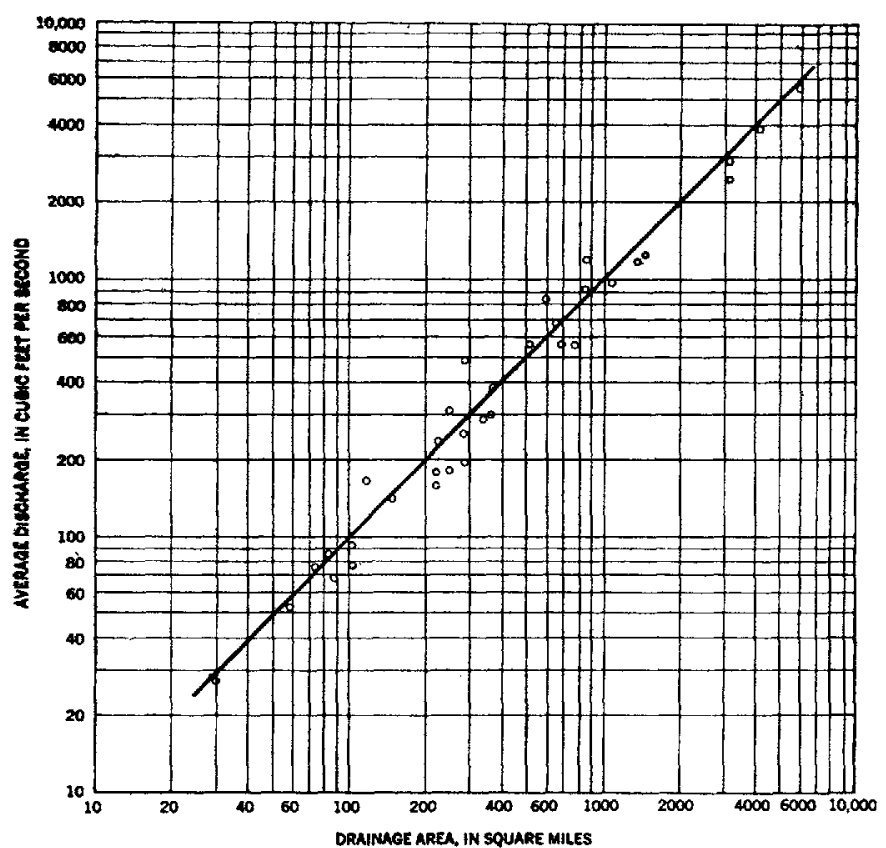

FraUne 15.-Logarithmic graph showing the relations between drainage area and discharge at gaging stations in the Potomac River basin above Washington, D.C. Data from U. S. Geological Survey Water-Supply Paper 1111.

This is shown by the scatter diagram of figure 15 , in which the average discharge determined at all the gaging stations in the Potomac River basin is plotted against the drainage area at these stations. The diagram shows that within narrow limits the average annual discharge in cubic feet per second equals the drainage area, measured in square miles. It must be kept in mind that the relation holds only for average annual discharge, which is probably not the most significant frequency of discharge controlling stream morphology. It must also be kept in mind that in detail, especially in small streams, there are significant departures from the conservative relation shown in figure
15. With these qualifications in mind, we may therefore substitute drainage area at a locality for discharge.

Drainage area has been plotted against channel slope for the localities in table 8 , and the paired values are shown in the scatter diagram, figure 16. The graph shows that in a general way channel slope decreases as drainage area increases. The scatter of points in the graph is large. If, however, the localities where the paired measurements were made are classified according to the geology of the area in which they lie, the scatter is considerably reduced. The introduction of a geologic classification of the localities results in a grouping of points that strongly suggests geologic controls for the values of the stream slopes. The differences in values from one area to another are large, for in the Tye River channel slopes are 10 to 15 times as great as they are in the Martinsburg shale area of the Shenandoah Valley, at the same drainage area. Not only are the values of slopes different in different areas, but the rates of change of slope are distinctly different. Thus in Gillis Falls and in the limestone area the rate of decrease of slope as area increases is relatively low. In the alluvial terrace area of the North River, however, it is several times higher than in the other streams.

\section{SIZE OF MATERIAL ON THE STREAM BED}

At each locality the median grain size of the material resting on the stream bottom was measured during the period of low water between June 15 and October 15, 1953, by the method described on page 48 . As the samples were taken from the surface of the stream bed, the figures for median size are representative of the surface material and not the material beneath, though there is, of course, a relation between the two. Study of all the data indicates that the size of the bed material may increase or decrease in a downstream direction, or remain constant, depending on the geologic nature of the drainage basin. The size of the bed material is one of the factors controlling slope in such a way that, for a given drainage area (or discharge), slope increases in proportion to a function of particle size.

General characteristics of stream-bed material.-General observations as to the nature of stream beds were made in the field, which bear upon the relation of slope to size. One of the most surprising observations so far as the writer is concerned is that the size of the material on the bed remains essentially constant for a fairly long reach of river and is not ordinarily affected by position in the channel with respect to pools and riffles. Several size analyses were made at localities close together in the Calfpasture River, and no variations were observed that had any discernible relation to local differences in channel width, depth, or slope. Table 1 shows figures for width, depth, local slope, and parameters describing size distribution at 3 


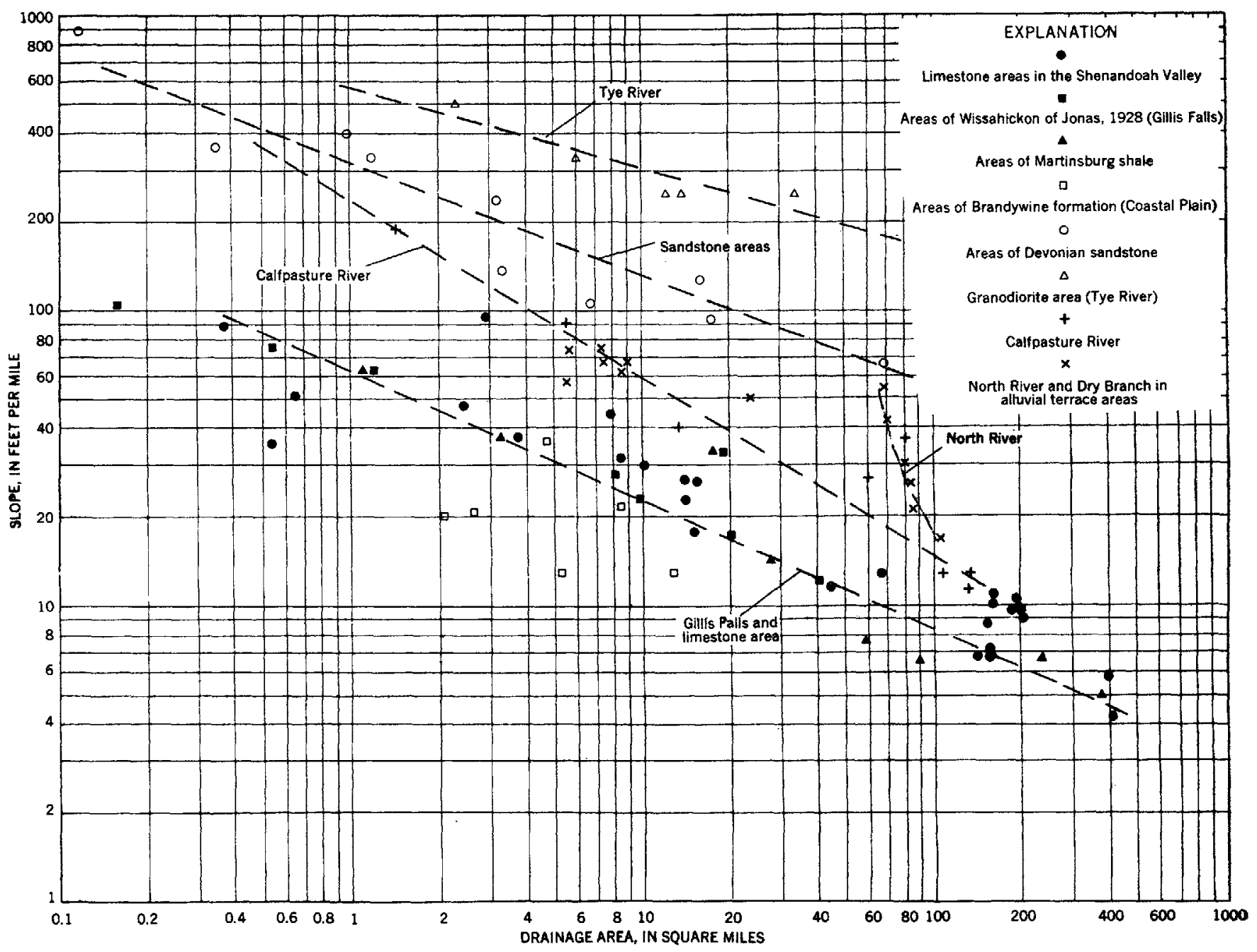

Fiaure 16.--Logarithmic scatter diagram showing the relation between channel slope and drainage area at the measurement localities (table 8).

localities within a reach 0.2 mile long. These localities are on the Calfpasture River, 24 miles from the head of the stream, where the average slope is 11.4 feet per mile.

TABLE 1.-Measurements at locality 654, Calfpasture River, to show variations in size of bed material in a short reach

\begin{tabular}{|c|c|c|c|}
\hline & $\begin{array}{c}\text { Riffle } \\
\text { Upper locality }\end{array}$ & $\begin{array}{c}\text { Pool } \\
\text { Middle locality }\end{array}$ & $\begin{array}{c}\text { Below pool } \\
\text { Lower locality }\end{array}$ \\
\hline \multicolumn{4}{|l|}{ Approximate river length } \\
\hline (miles) & 24.0 & 24.1 & 24.2 \\
\hline Width $\ldots \ldots$ (feet) & 82 & 99 & 120 \\
\hline Average depth & 2.6 & 2.9 & 1.6 \\
\hline Local slope _ (feet per mile) & 28 & 0 & 18 \\
\hline $\begin{array}{l}\text { Median size of bed ma- } \\
\text { terial } \ldots \ldots \text { (millimeters) }\end{array}$ & 62 & 75 & 53 \\
\hline 1st quartile _ (millimeters) & 106 & 123 & 64 \\
\hline 3rd quartile__(millimeters) _. & 50 & 50 & 32 \\
\hline Trask sorting coefficient.... & 1.6 & 1.5 & 1.4 \\
\hline
\end{tabular}

Many measurements of particle size, several of them very closely spaced, were made in the Middle River, in the limestone region. In this area the Middle River has a considerable flow even in the driest seasons and low-water depths are 4 feet or more in some pools. In this region size of bed material was rather closely correlated with its lithologic nature, but not with the position of pools and riffles. The only conspicuous changes in size within short reaches occur at the lower ends of some riffles, where, during low-water periods, sand is transported down the riffle and deposited in a small delta at the upper end of the pool.

In some small streams, particularly in the limestone region, plants such as water cress grow locally in profusion. The plants collect fine particles and form wide mud banks a few inches thick on top of the gravel. At other places, especially where there are steep banks of fine material, the banks may collapse at low-water periods and spread a layer of mud over the outer edge of the channel gravel. Such localities were avoided in selecting sites for size analyses.

Within a single reach of river, greater variations in size 


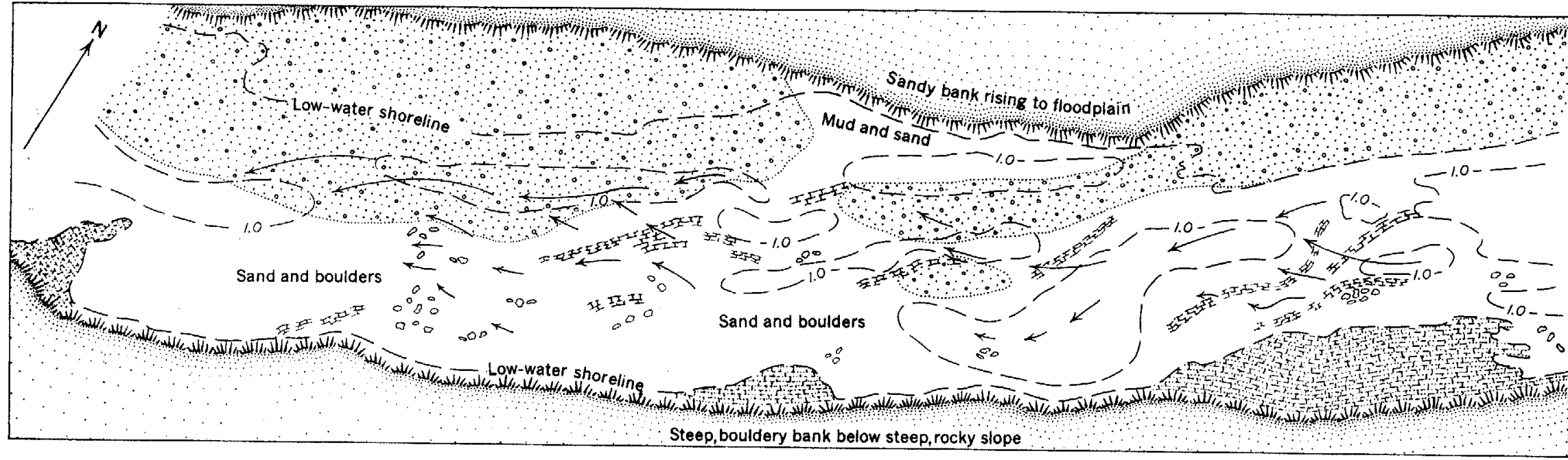

Steep, bouldery bank below steep, rocky slope

25 0

50 Feet

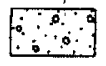 \\ Pritin \\ 조조조로모

$$
80000
$$

EXPLANATION abovtone boulders projecting
abow water
Direction of stream flow Length of arrow proportional to velocity

Fraune 17.-Plan of short reach of Middle River above Franks Mill at locality 615, showing the character of the stream bed. In this reach the river flows from east to west at a sharp bend. 
of material are observed in a cross section of the stream bottom than in a longitudinal section. These differences, however, were averaged out by the method of analysis that was used, because the grid by which the boulders and pebbles were selected always included the entire width of the bed. Few statistical data are available, therefore, on lateral variation in size. Bars of fine gravel are common, especially on the inner side of bends, and the coarsest boulders are in places concentrated in the deepest parts of the channel; though not necessarily where the low-water flow is the swiftest. Figure 17 is a plane-table sketch showing the depth of water and the position of rock outcrops, large boulders, and gravel bars at a typical riffle.

Probably the bed material of the rivers in this region is moved only at periods of high water. In low water, movement is restricted to fines that get into the river by the slumping of banks or in wash off the land surface. There is little deposition at low water and even the low flow is probably sufficient to carry away most of the fines. Rivers such as the upper part of the North River, East Dry
Branch, and the Calfpasture River are dry most of the year: The bed material in these rivers shows no evidence of a coating of fines, such as might be expected if fines are dropped during the waning stages of a flood. Although downstream variations in size in a given reach seemed to be small, size analyses were most often made at the upstream end of riffles, in the interest of uniformity.

The sorting observed in the size analyses is good. Trask sorting coefficients generally range from 1.5 to 2.5 and average about 2.0. An exception to this generality occurs in the upper reaches of ephemeral streams that have gentle slopes, where the sorting coefficient becomes high, generally exceeding 4.0. This poor sorting is probably due to the fact that the amount of fine-grained soil material supplied to the flowing water greatly exceeds the coarse. As the flow is ephemeral and seldom attains high velocities, the material carried, and hence the material making up the bed, is predominantly fine and becomes mixed with the pebbles and boulders that are the product of infrequent flood flows. Measurements made at such localities, where

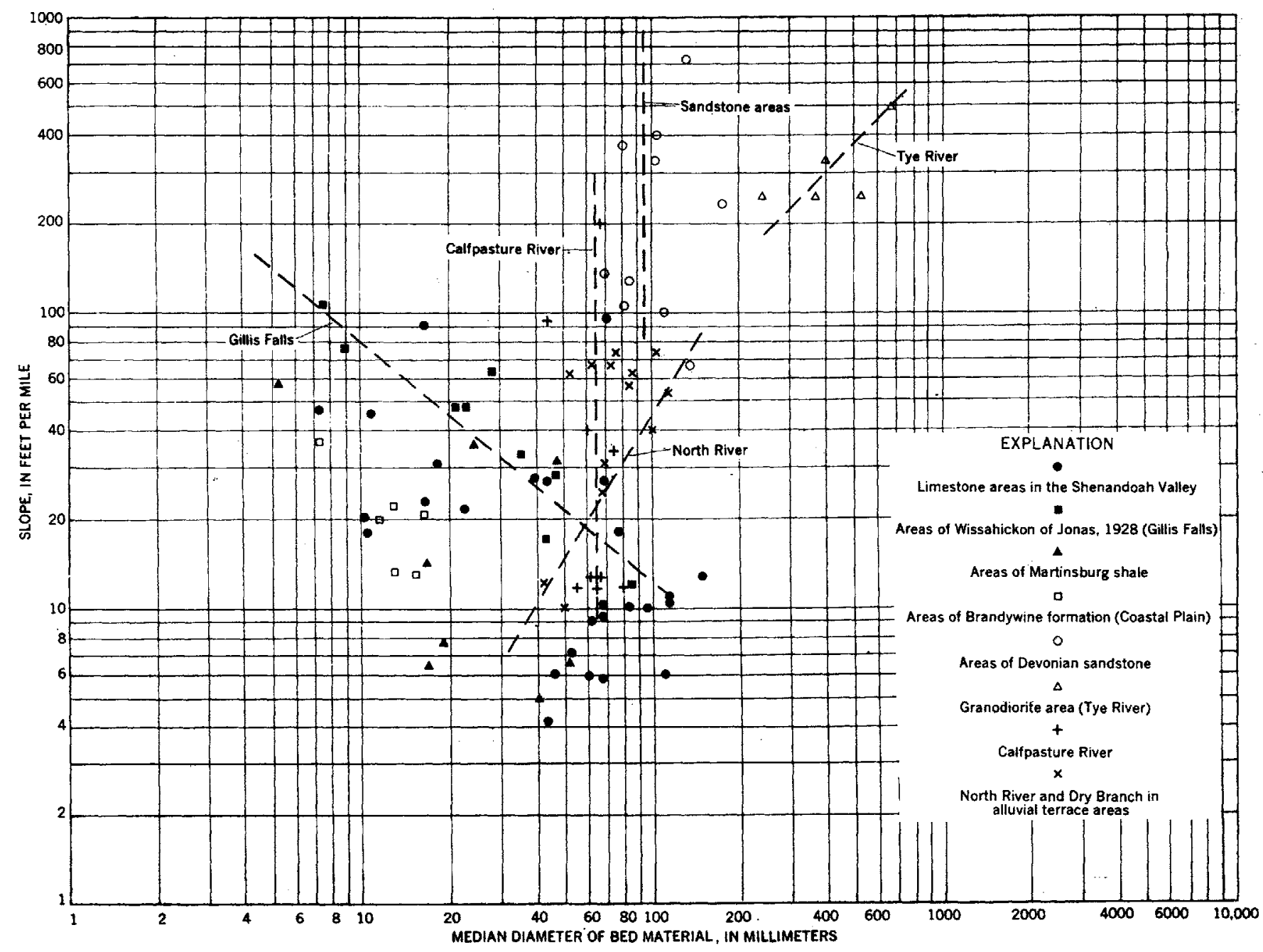

Figvre 18.-Logarithmic scatter diagram showing the relation between channel glope and median size of bed material at the measurement localities (table 8 ). 
sorting is poor, are not used in the analysis of slopes in this report (see p. 85). In steep, mountainous terrain, however, sorting coefficients remain low even in extremely small channels.

Relation of median particle size to slope.-Although local variations in bed material size are small, the overall change in a single stream may be great. In Gillis Falls, for example, discussed on page 69 , the median size of bed material was observed to increase from 7 millimeters to 85 millimeters in a distance of 10 miles. The relation between size and slope for all the streams is shown on the scatter diagram, figure 18. The diagram demonstrates that there is no apparent direct correlation between size and slope if all the localities are considered. In streams whose bed load has a median size of 100 millimeters, for example, slopes may range from 6 feet per mile to over 1,000 feet per mile. In some individual streams, however, or in groups of streams classed according to the geology of their basins, there is a systematic relation between the two variables. In Gillis Falls size increases as slope decreases. In the Calfpasture River and in the Devonian sandstone areas size seems to remain essentially constant, regardless of the slope.

The variations in the relation between size and slope are clarified if a third factor, drainage area, is taken into account. Figure 19 is a scatter diagram in which channel slope, $S$, is plotted against the ratio of the size of bed material to drainage area $(M / A)$. The points in the diagram are clustered in a field about a line, drawn by inspection through the points. This line may be expressed by the equation

$$
S=18\left(\frac{M}{A}\right)^{0.6}
$$

where $S$ is channel slope in feet per mile, $M$ is median particle size of the bed material in millimeters, and $A$ is drainage area in square miles. The constant, 18 , is determined by the units of measurement used. This equa-

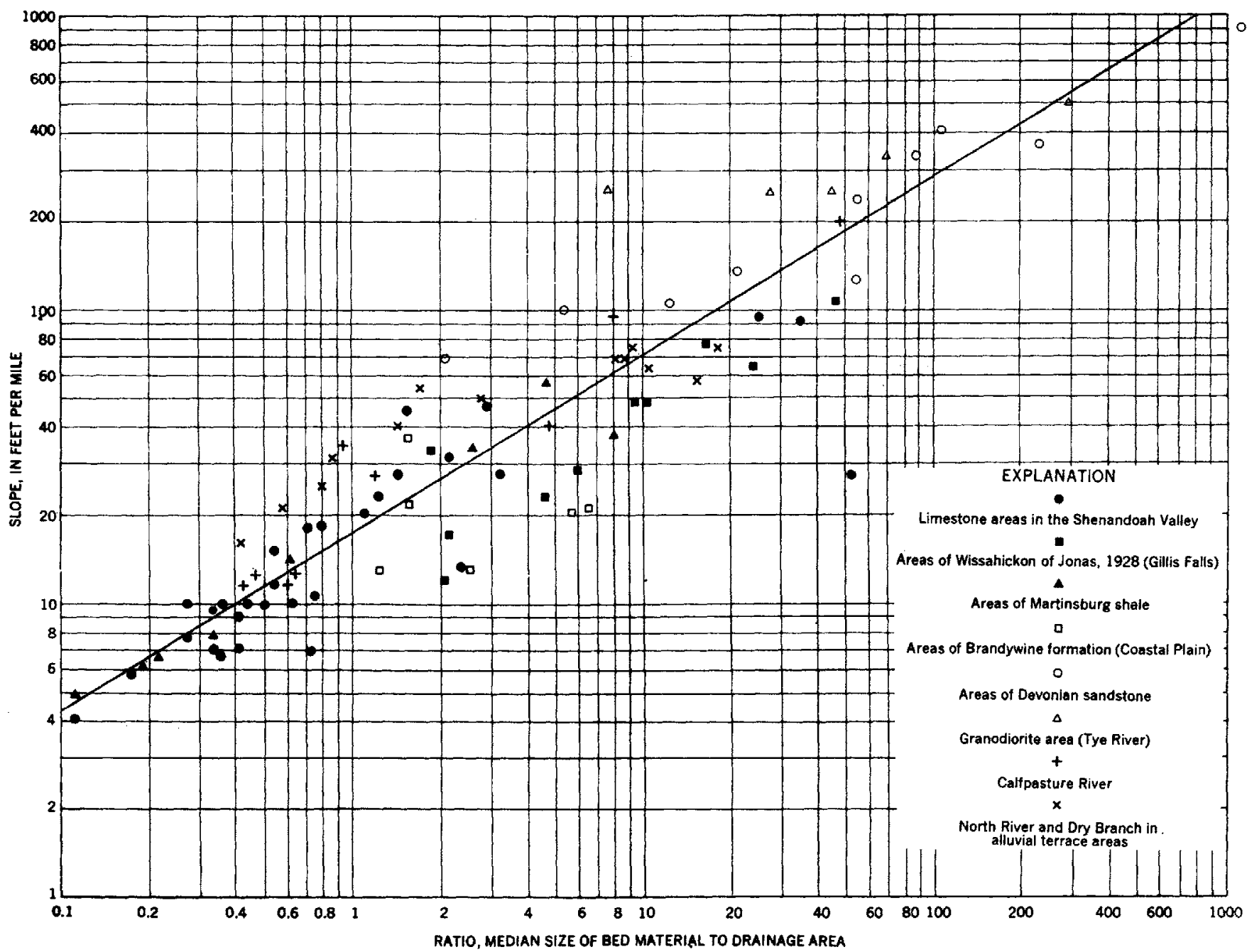

Frourf 19.-Logarithmic graph showing the relation between channel slope and the ratio of median size of bed material to drainage area, at the measurement localitios. 
tion states simply that slope is directly proportional to the 0.6 power of the ratio of grain size to drainage area. In terms of the relation between the three individual variables, the equation states that for any given drainage area, slope is directly proportional to the 0.6 power of the size of bed material, and for any given size, slope is inversely proportional to the 0.6 power of the drainage area.

The correlation between slope and the ratio $M / A$ is far better than the correlation between slope and either $M$ or $A$ plotted separately (figs. 16 and 18). Not only is the field of scatter greatly reduced, but the inclination of the lines drawn through localities along individual classes of streams (such as the Calfpasture River or the Devonian sandstone areas) are more nearly the same. In consideration of the data available and the difficulties involved in measurement, the correlation seems good. Furthermore, the variables considered in this graph are only three of several more, such as channel cross section and amount of load, that we know are involved in the problem. No one individual stream except the Calfpasture River fits the equation exactly. Nevertheless equation 2 may be considered an empirical generalization that expresses the relations between the three independent variables: slope, drainage area, and size of bed material.

Another way to determine the relation between the three variables would be to plot on a graph the relation of slope to size for localities on different streams having the same drainage areas; in other words, to compare slope and size at a constant drainage area. The data obtained in the field are simply not adequate to determine quantitatively the relations between the variables by this means. It is shown by the graph of figure 20 , however, that for streams within a certain range of drainage areas, slope increases directly as size of bed material increases. Two groups of localities were chosen, one at drainage areas of 1 to 10 square miles and the other at drainage areas of 50 to 100 square miles. Each of these groups encompasses a wide range in slope value.

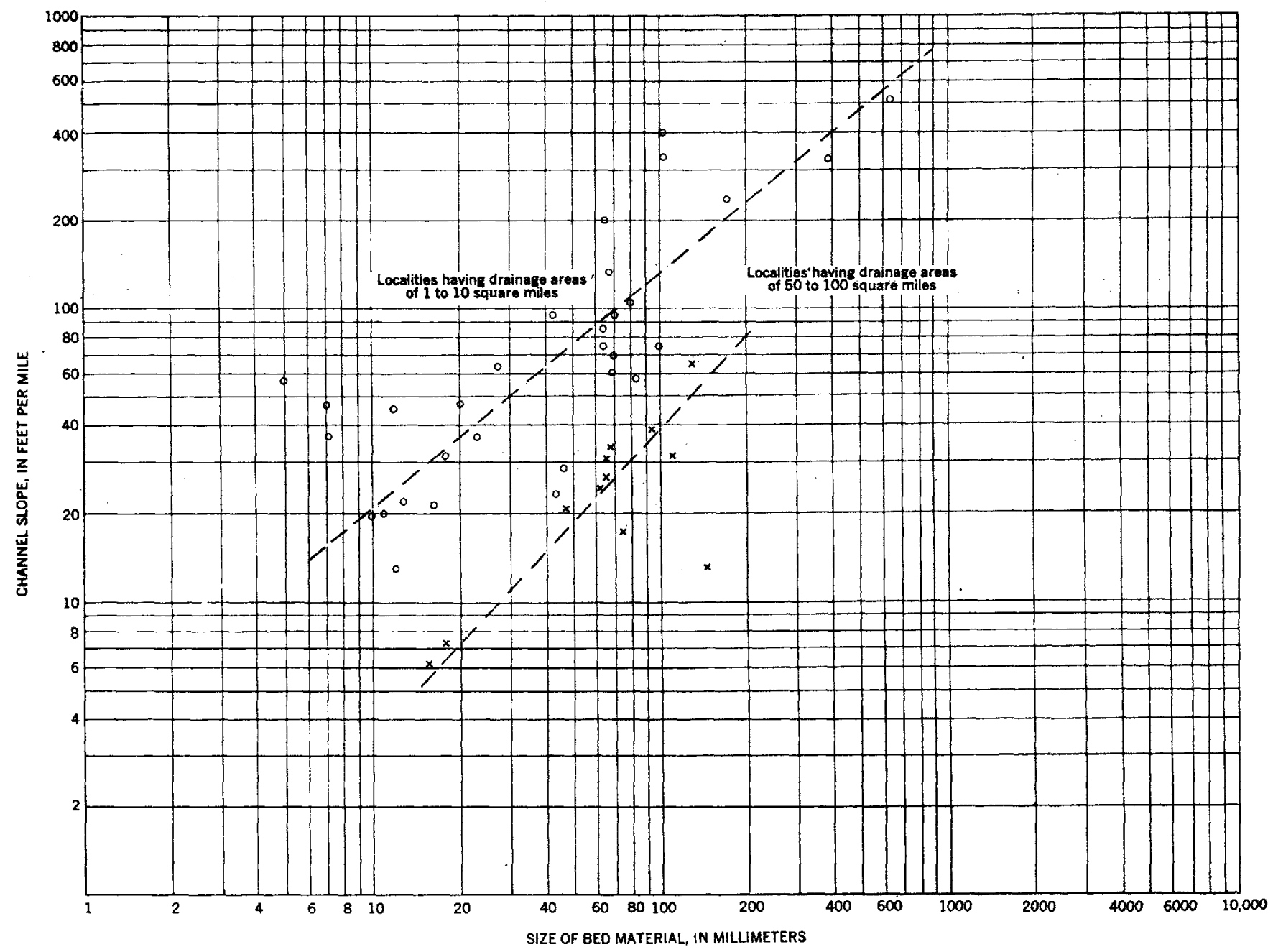

FIGURE 20.-Graph showing the relation between the slope and the size of the bed material at stream localities having drainage areas hetween 1 and 10 square miles and between 50 and 100 square miles. 


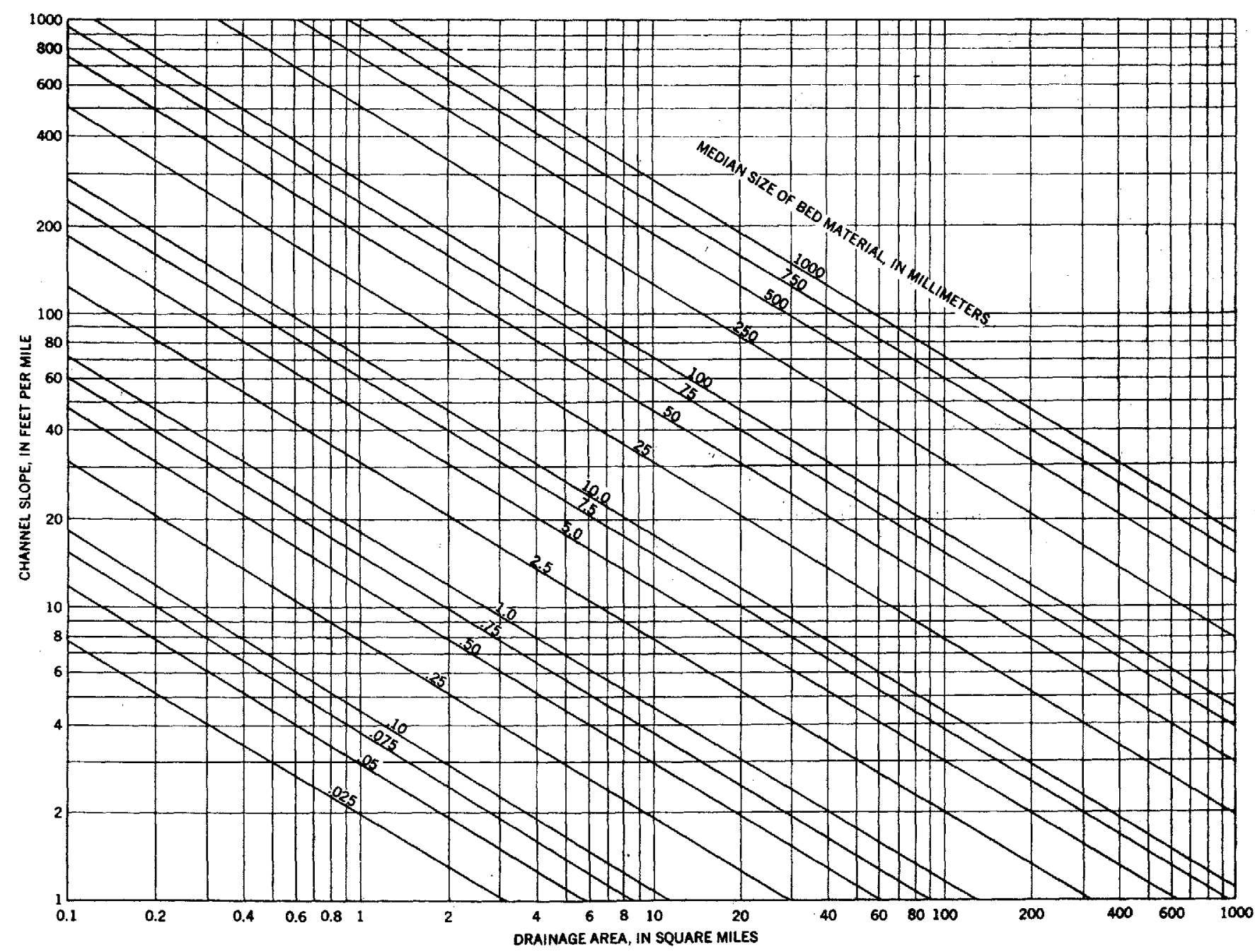

FravRe 21,-Three-component diagram showing the general relation among channel slope, drainage area, and size of bed material, expressed by the equation $S=18(M / A)$ o. 0.

The general relation among the three variables based on equation 2 are shown in the three-component diagram, figure 21. The diagonal lines have a slope of -0.6 . They represent lines of equal bed-material size and illustrate the effect of changes of size of bed material on changes in channel slope. Proceeding downstream (increasing discharge), for example, if bed-material size remains the same, the slope decreases as the 0.6 power of the drainage area increases. If bed-material size increases in a downstream direction, the slope will decrease less sharply in proportion to some power greater than the -0.6 , such as -0.3. If the increase in grain size is very sharp, the slope may remain constant or even increase. On the other hand, if size decreases as area increases, the decrease in slope will be very sharp. 


\section{CHANNEL CROSS SECTION}

Measurements of cross-sectional areas, widths, and computed mean depths were made at most of the localities and are included in table 8. Measurements of channel width and average depth are plotted with respect to drainage area in figure 22. They show, as Leopold and

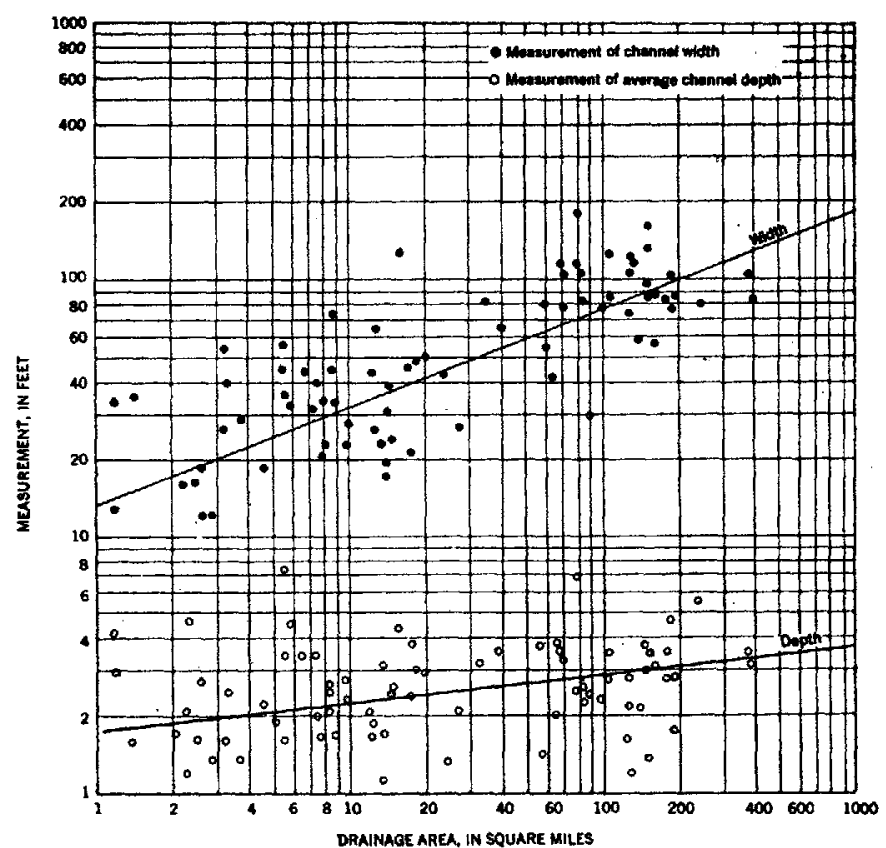

Fradre 22.-Logarithmic scatter diagram showing the relation between width and drainage area (upper graph) and depth and drainage area (lower graph) at all the localities measured (table 8). The lines through the clusters of points are drawn by inspection and because of the large variation have no quantitative value.

Maddock (1953) found from data at stream gaging stations, that width increases in a downstream direction and suggest likewise that depth increases downstream. The rate of change of width as drainage area increases is greater than the rate of change of depth. As a consequence, the ratio of depth to width decreases downstream.

The ratio of depth to width is plotted on figure 23 . In this diagram, as in several others, the localities are classified according to geologic criteria and lines are drawn through points on streams that show a rough correlation between the depth-width ratio and drainage area. Although variations in depth-width ratio are large and apparently unsystematic if all the localities are considered, variations in the ratio within areas having the same bedrock correlate well with drainage area. This suggests that the form of the cross section of the channel is in some way related to the rocks that enclose it. The shallowest cross sections are in the mountain areas, particularly in the Calfpasture River. The deepest cross sections are in the lowlands of the Shenandoah Valley, the piedmont of Maryland, and the coastal plain. Depth-width ratios for Dry Branch and the North River in the alluvial terrace areas are high, but they decrease at anomalous rates.

The significance of the data bearing on depth-width ratio is not understood. The data are in accord with the statement of Rubey (1952, p. 133) that most natural streams probably become proportionately wider downstream, and with the theory that the depth-width ratio, like slope, is a dependent variable such that either this ratio, or channel slope, or both may adjust to changes in load or discharge. Several attempts have been made to relate, on scatter diagrams, ratios including slope, depth, and width on one axis to bed-load size and drainage area on the other. The data, however, do not seem to permit any refinement of the relation expressed by equation 2 that

$$
S=18\left(\frac{M}{A}\right)^{0.6}
$$

\section{SUMMARY OF FACTORS CONTROLIING CHANNEL SLOPE}

The data obtained at the measurement localities studied for this report indicate that the channel slope of rivers whose bed material is of the same size is inversely proportional to a function of drainage area (or discharge), and where drainage area is the same, it is directly proportional to a function of the size of the bed material. This generalization holds roughly for a stream with a drainage basin of only 0.12 square miles as well as a stream draining over 370 square miles, the largest river reach studied. Equation 2, which summarizes the generalization, is empirical. It does not indicate that either size of bed material or drainage area must be the principal direct determinant of slope, but it is a useful equation because it deals with size of bed material, a factor in stream equilibrium that must be a function of geologic conditions.

One of the most significant results of the analysis of the data is the finding that areas which have the same geology and drainage area are adjusted to load, slope, and channel cross section in the same way. Thus the classification of the localities according to a scheme that emphasizes the lithologic nature of the drainage basin results in a grouping of points much closer than the total grouping in many of the diagrams. For example, the localities in the Devonian sandstone area tend to have relatively steep slopes for equivalent drainage areas as compared with localities in other geologic regions (fig. 16). The bed material is nearly of the same size in the various localities in the sandstone area (fig. 17), and the depth-width ratios are distinctive (fig. 23). The same sort of generalization could be made about streams in other lithologic environments. Since drainage area is one of the variables in each of these diagrams we may conclude that streams within a single geologic unit that have equivalent drainage 


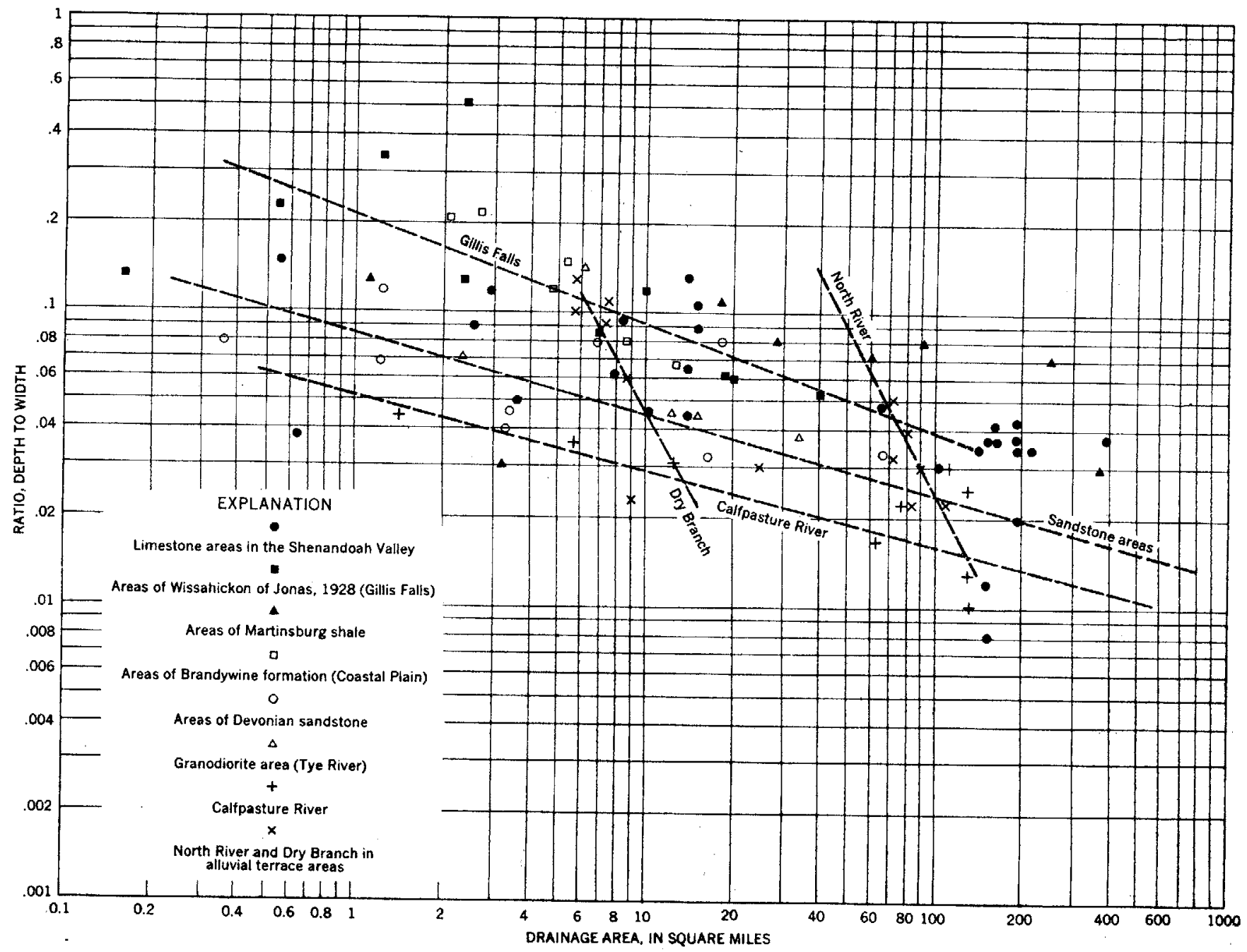

FraURE 23.-Logarithmic scatter diagram showing the relation between depth-width ratio and drainage area at the measurement localities (table 8). 
areas have also similar channel slopes, size of bed material, and, from figure 23 , channel cross sections.

\section{FACTORS DETERMINING THE POSITION OF THE CHANNEI IN SPACE: THE SHAPE OF THE LONG PROFILE}

The longitudinal profile of a stream can be expressed as the relation between fall, or the vertical distance below the source, and length, or horizontal distance from the source. For many rivers the curve that expresses this relation has a parabolalike shape, steep near the source and gradually flattening as the length increases. The slope of the channel at any point is simply the tangent to the profile at that point. If the profile of a stream can be expressed by an equation, the relation between channel slope and stream length can be determined easily, since this relation is simply the first derivative of the profile. Conversely, if the relation between slope and length is known, the profile can be determined by integration.

\section{RELATION OF STREAM IENGTH TO DRAINAGE AREA}

The relation of length to drainage area, or the rate at which drainage area increases in a downstream direction, is an important factor affecting the longitudinal profile. If bed-material size is the same, slope, as has been shown, is related to drainage area. Therefore the rate of decrease of slope with respect to length in a downstream direction is directly related to the rate of increase of area with respect to length. Another way of stating the relation is to say that, for a given size of bed material, the absolute value of the channel slope at any point on a stream is approximately determined by the drainage area (or discharge). Slope, however, is a function of length and fall, for it is the tangent to a mathematical curve that represents the longitudinal profile. It is apparent that the channel slope of a stream might be decreased because of either a decrease in the fall between two points or an increase in the length, as, for example, by the development of meanders.

That this concept is important in the description of the profile is illustrated by the two profiles shown in figure 24 . Profiles of streams A and B are drawn so that both have slopes of 100 feet per mile at a length of 1 mile. At 10 miles stream $\mathrm{A}$ has a slope of 10 feet per mile, whereas stream B, because of a more rapid increase in the area of its basin, has a slope of 10 feet per mile at only 5 miles. As shown in the illustration the two profiles are markedly different.

It has long been known that stream systems are arranged in an orderly fashion (Horton, 1945, p. 286 and Langbein, 1947), and that length, if measured as defined on page 47 , and drainage area are interdependent quantities such that one changes with respect to the other at a rate that appears to be roughly uniform over large areas, regardless of the geologic conditions of the region. Figure 25 shows this relation as it exists at all localities visited in this study. The paired values are grouped closely about a line expressed by the equation

$$
L=1.4 A^{0.6}
$$

where $L$ is length in miles and $A$ is the area in square miles. The relation was further checked by plotting 400 similar measurements made by Langbein at gaging stations in the northeastern United States (Langbein, 1947, p. 145). Although the results of this plotting are not reproduced here, the values measured by Langbein are grouped about a line expressed by the same equation 3 as the line of figure 25. Thus, it is fairly well demonstrated that in the northeastern United States the length of a stream at

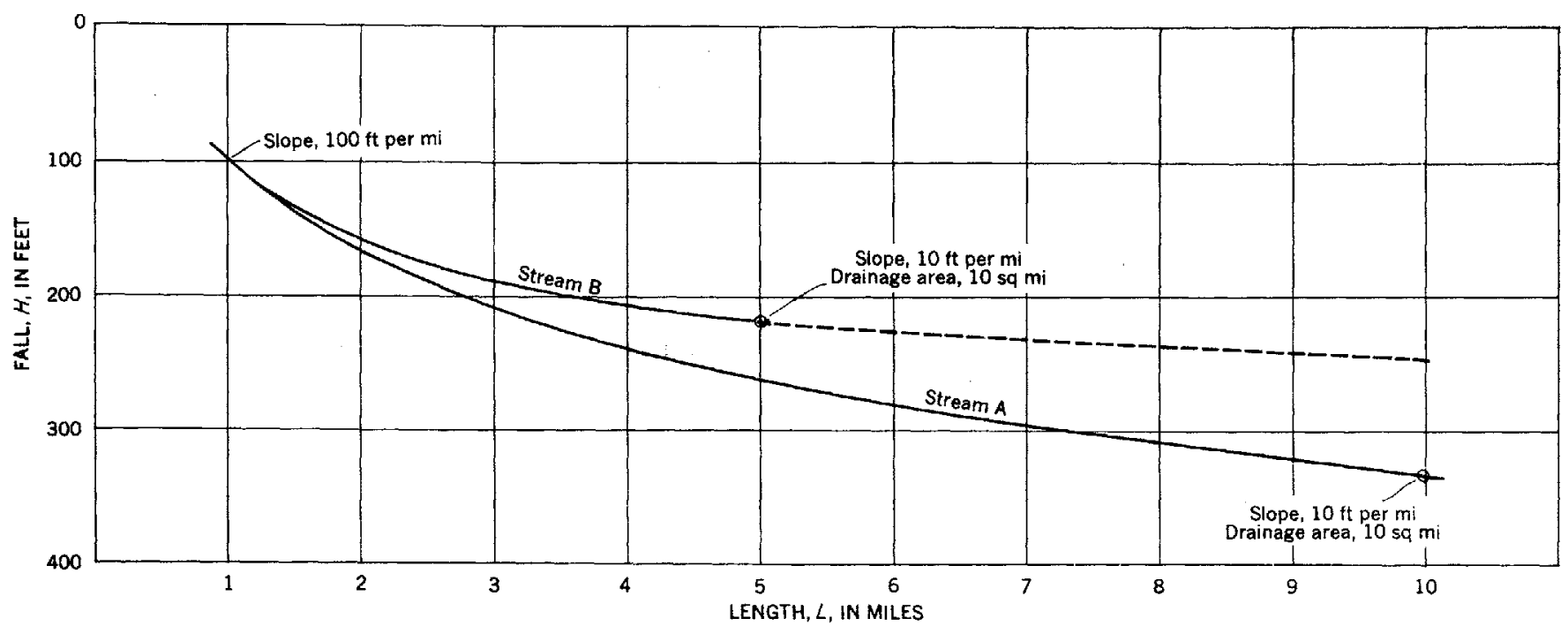

Figure 24.-Profiles of hypothetical streams A and B, which have the same relation between slope and drainage area but a different relation between length and drainage area. 


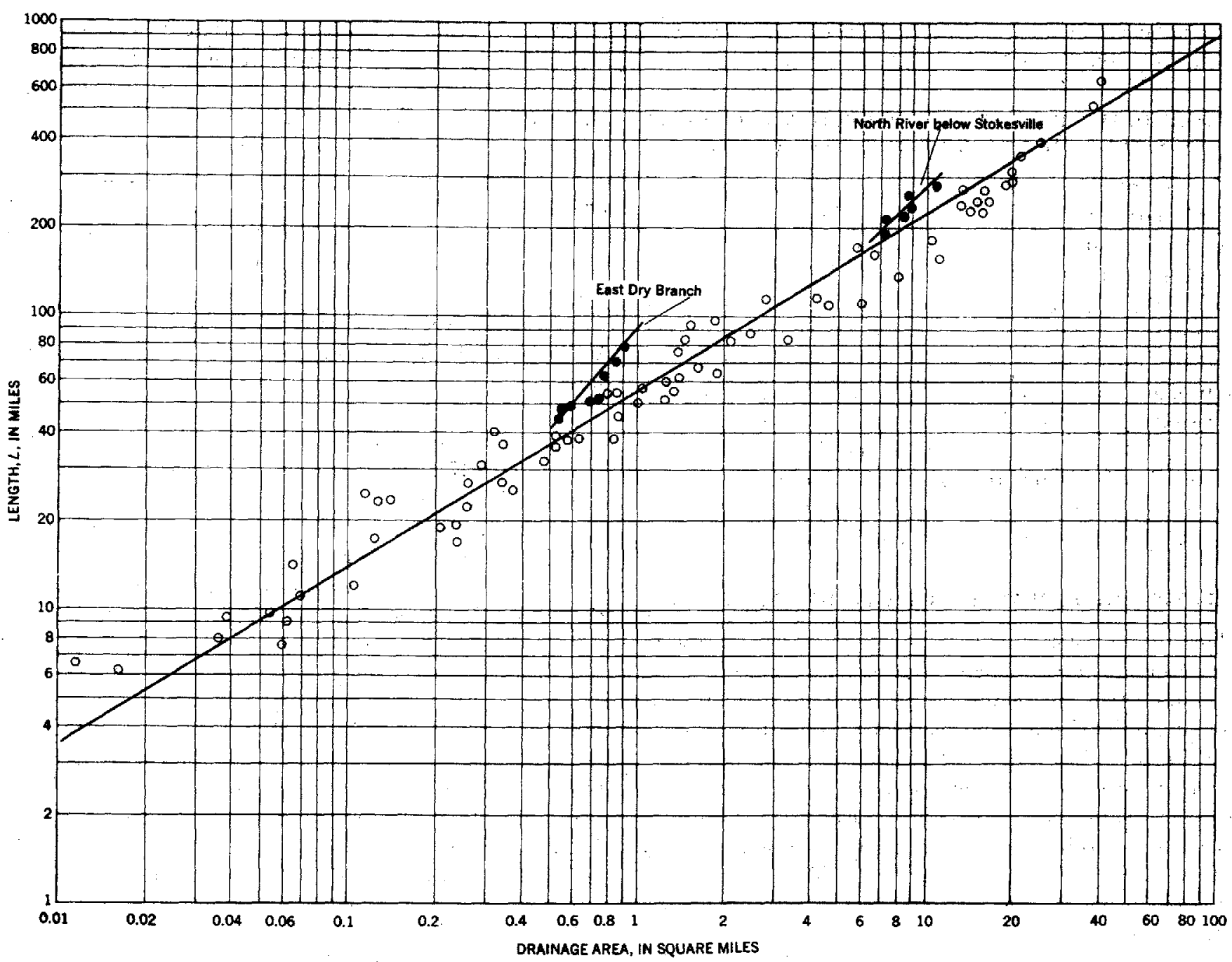

FIafre 25,-Logarithmic scatter diagram showing the relation between length and drainage area at all the measurement localities. Localities in East Dry Branch below the sandstone area and on the North River are shown in solid black.

any locality is, on the average, proportional to the 0.6 power of its drainage area at the locality.

Length and drainage area measurements were also made of two areas in the western United States in order to determine whether the relation is general. Measurements of streams eroding bedrock areas in the Mingus Mountain quadrangle, Arizona, indicate a relation between area and length that is equally conservative, but in that region the length is proportional to the 0.7 power of the drainage area. Similar values were obtained for points on streams on the east side of the Black Hills, S. Dak. We may therefore be sure that the relation defined by equation 3 can be considered valid only for the region under discussion in this report.

Examination of figure 25 shows that there are significant departures from the relation expressed above, and that it can be considered valid only within limits. It is obvious that on any stream the length must increase downstream more rapidly than the 0.6 power of the area between all the major tributaries. There are stream reaches along which no large tributaries enter for long distances, and in these reaches the length must increase at a more rapid rate; this general principle applies to short as well as long streams.

In figure 25, two specific cases of departure from the general relation between length and area are emphasized by solid circles. They occur on East Dry Branch and the North River. The length of East Dry Branch increases at a more rapid rate than area over a distance of 4 miles. On the North River a similar increase occurs over a distance of 15 miles. In both streams, the relation observed seems to be associated with similar geologic conditions. Their sources are in rough mountainous terrain in the Devonian sandstone area of Augusta County, Va., west of the limestone region of the Shenandoah Valley (pl. 9). In this region their valleys have fairly narrow flood plains 
and the relation between area and length is that of equation 3. On entering the limestone area, however, they deposit their load of coarse sandstone gravel on broad flood plains-in the case of the North River, almost a mile wide. Because of the aggradation and shifting of the channel which occurs on these wide flood plains, minor tributaries do not enter the streams directly but flow into the valley at the outer edge of the flood plain, turn downstream and run for a considerable distance parallel to the main stream. Therefore no large tributaries enter the main streams of the North River and East Dry Branch for long distances.

Irregularities similar to those on parts of East Dry Branch and the North River occur locally along short reaches of other streams, but the general regularity of the relation of stream length to drainage area for the region is nonetheless remarkable. Stream lengths tend to increase proportionally to the 0.6 power of the drainage area, regardless of the geological or structural characteristics of the area. The coefficient of the equation relating length and area averages around 1.4 but ranges between 1 and 2.5. That is to say, a drainage basin of one square mile will, on the average, contain a principal stream 1.4 miles long. The data also show that for the sandstone areas the coefficient tends to be larger than for other areas; the average in sandstone is around 2.0.

It is clear that drainage basins must change their overall shape in a downstream direction, becoming longer and narrower as they enlarge. Larger basins are more elongate; that is, more pear-shaped or cigar-shaped than small ones. If the drainage basin retained the same shape as it enlarged, the length would be proportional to the 0.5 power of the area, rather than the 0.6 power. The concept is perhaps clarified by a consideration of a dimensionless expression, the ratio of average width to length. The average width of a drainage basin, designated $W_{a}$, consists of the drainage area of the basin, $A$, divided by the length of the longest stream, $L$, so that $W_{a}=A / L$ and $A=W_{a} L$. Substituting in equation 3 ,

and

$$
\begin{aligned}
L & =1.4\left(W_{a} L\right)^{0.6} \\
L^{1.66} & =1.75 W_{a} L, \\
W_{a} / L & =0.57 / L^{0.33} .
\end{aligned}
$$

The ratio of width to length, therefore, increases inversely as the third power of the length and must decrease as the length increases. If, however, the length were proportional to the 0.5 power of the area, then the width-length ratio would remain constant (where $k$ is any constant):

$$
\begin{aligned}
\text { If } & L & =k\left(W_{a} L\right)^{0.5} & \\
& \text { then } & L^{2} & =k^{2} W_{a} L \\
& \text { and } & W_{a} / L & =1 / k^{2} .
\end{aligned}
$$

This general change in basin shape between amall and large basins is related to the internal geometry of the drain- age pattern. A clue to its significance may be found in Horton's general formula for the composition of drainage networks (Horton, 1945, equation 17, p. 293). Horton derived, by a consideration of the branching patterns of streams of different orders, the following general equation:

$$
D_{d}=\frac{l_{1} r_{b}^{s-1}}{A} \cdot \frac{\rho^{s}-1}{\rho-1} .
$$

In this equation $D d$ is the drainage density defined as the ratio of the length of all streams in the drainage basin to the drainage area, generally measured in miles per square mile; $l_{1}$ is the average length of streams of the first order; $r_{b}$ is the bifurcation ratio or the ratio between the number of streams of one order to the number of streams of the next higher order; $r_{l}$ (included in the expression $\rho$ in this equation) is the length ratio or the ratio between the average lengths of the streams of one order to the average lengths of the streams of the next lower order: $A$ is the total area of the basin (having a principal stream of order $s$ ): $\rho$ is the ratio $r_{l} / r_{b}$ or the ratio of the length ratio to the bifurcation ratio.

This general equation of Horton's contains an expression for the area $A$, of a stream of order $s$, but there is no expression in the equation for the length of the principal stream. We may, however, use Horton's method of analysis to obtain equations for the length and the drainage area of the principal stream of any order $s$ :

Let $L_{s}$ represent the length of the principal stream of an average drainage basin of order $s$. Then

and

$$
\begin{aligned}
& L_{1}=l_{1}, \\
& L_{2}=l_{1} r_{l}, \\
& L_{3}=l_{1} r_{l} \cdot r_{l}=l_{1} r_{l}^{2}, \\
& L_{4}=l_{1} r_{l}^{3}, \\
& L_{s}=l_{1} r_{l}^{l^{-1} .}
\end{aligned}
$$

Similarly let $a_{1}$ represent the average drainage area of first-order streams; and let $A s$ represent the drainage area of the principal stream of order $s$. Then

and $A_{2}=a_{1} r_{b}+a_{1} r_{l}$, because the quantity $a_{1} r_{b}$ is simply the sum of all the drainage areas of all the first-order streams. In addition to this there is the area draining directly into the one principal stream of order 2. Since the length of overland flow is about the same for all streams, the area that drains directly into a second-order stream must have the same average width as the area that drains directly into the first-order stream, and as the channel lengthens the area draining directly into it overland increases in proportion to its length. Therefore the quantity $a_{1} r_{l}$ represents the area of overland flow draining into the channel of the principal stream itself. Similarly, therefore, 


$$
\text { and } \quad \begin{aligned}
A_{3} & =\left(a_{1} r_{b}+a_{1} r_{l}\right) r_{b}+a_{1} r_{l} \cdot r_{l} \\
& =a_{1}\left(r_{b}^{2}+r_{l} r_{b}+r_{l}^{2}\right) \\
A_{4} & =a_{1}\left(r_{b}^{3}+r_{b}^{2} r_{l}+r_{b} r_{l}^{2}+r_{l}^{3}\right) .
\end{aligned}
$$

This expression may be transformed to the following:

$$
A_{4}=a_{1} r_{b}{ }^{3}\left(1+\frac{r_{l}}{r_{b}}+\frac{r_{l}^{2}}{r_{b}{ }^{2}}+\frac{r_{l}{ }^{3}}{r_{b}{ }^{3}}\right)
$$

and

$$
A_{s}=a_{1} r_{b}^{s-1}\left(1+\frac{r_{l}}{r_{b}}+\frac{r_{b}^{2}}{r_{b}^{2}}+\frac{r_{l}^{3}}{r_{b}^{3}}+\ldots . \frac{r_{l}^{s-1}}{r_{b^{s-1}}}\right) .
$$

If $r_{l} / r_{b}=\rho$, following Horton, this equation can be simplified to

$$
A_{8}=a_{1} r_{b}^{s-1} \cdot \frac{\rho^{s}-1}{\rho-1} .
$$

We now have two useful equations expressing the length and area of a principal stream of order $s$.

Relating equation 7 to Horton's equation 17 (Horton, 1945, p. 293) it is seen that $D d$ must equal $l_{1} / a_{1}$ for a drainage basin of any order $s$ and is a constant.

Multiplying both sides of Horton's equation 17 by $A / D_{d}$ and then substituting $l_{1} / a_{1}$ for $D_{d}$ we get

$$
A=\frac{l_{1} r_{b}^{s-1}}{\frac{l_{1}}{a_{1}}}: \frac{\rho^{s}-1}{\rho-1}
$$

which is the same as equation 7 .

Actually in most natural drainage basins the drainage density probably does not remain constant as the order of the stream is increased ${ }^{1}$. This may be because natural drainage areas are rarely homogeneous and other constants change as drainage areas become larger. It may be because the equations just derived as well as Horton's equation are only approximations and do not fit natural streams perfectly.

The relation of equation 6 to 7 may now be considered. At a point on the principal stream of a basin of order $a$, where the stream length is equal to the average length of streams of order $s, L$ and $A$ are related in most streams so that

$$
L=1.4 A^{0.6} \text {. }
$$

We have shown that $L_{s}=l_{1} r_{l}{ }^{8-1}$

and

$$
A_{8}=a_{1} r_{b}{ }^{s-1} \cdot \frac{\rho^{s}-1}{\rho-1} .
$$

Therefore the values of the four quantities $l_{1} a_{1} r_{l}$ and $r_{b}$ must determine the coefficient and exponent in equation 3 , above.

The relation between these quantities is so complex that their meaning cannot readily be appreciated simply by inspection of the equations. Using an actual drainage basin as an example, however, numerical values for the various factors may be obtained and a comparison made. Accordingly, an analysis of the Horton type has been made of the drainage basin of Christians Creek, Va. This basin is chosen because it is entirely in low countrymostly in Martinsburg shale-and therefore can be ex-

\begin{tabular}{|c|c|c|}
\hline$s$ & $L$ & $A$ \\
\hline 1 & 0.35 & 0.077 \\
\hline 2 & .83 & .246 \\
\hline 3 & 2.0 & .788 \\
\hline 4 & 4.8 & 2.52 \\
\hline 5 & 11.5 & 8.06 \\
\hline 6 & 27.6 & 25.8 \\
\hline
\end{tabular}
pected to be relatively homogeneous, although quite large in area. The following values for the various factors of Horton are obtained:

and

$$
\begin{aligned}
r_{l} & =2.4, \\
r_{b} & =3.2 \\
\rho & =2.4 / 3.2=.75, \\
l_{1} & =.35 \\
D_{d} & =4.55
\end{aligned}
$$

and, since $D_{d}=l_{1} / a_{1}$, then $a_{1}=.077$.

Using equations 6 and 7 , the values of $L$ and $A$ for various orders can be calculated.

When the values of $L$ 's and $A$ 's are plotted on logarithmic scales they form a row of points that is slightly curved but approximates a straight line having the equation $L=1.5 A^{0.65}$, as shown in figure 26 by the line $B-B^{\prime}$. Actual measurements of length and drainage area at points within the drainage area of Christians Creek line up along line $C-C^{\prime}$ in fig. 26. This line is close to $B-B^{\prime}$ and has the equation

$$
L=1.5 A^{0.62} .
$$

Consideration of figure 26 shows that the value of the coefficient in the equation relating length and area of points on Christians Creek and represented by the lines $B-B^{\prime}$ and $C-C^{\prime}$ must be closely related to and be a function of drainage density; whereas the exponent in this equation is related to Horton's $\rho$ defined as the ratio $r_{i} / r_{b}$. Consider first the coefficient. The coefficient is the value of the stream length at a drainage area of one mile. In the case of Christians Creek the coefficient is approximately 1.5 , measured by the intercept of the line $C-C^{\prime}$ or $B-B^{\prime}$ at 1 square mile. The coefficient can be changed either by changing the value of $a_{1}$ or the value of $l_{1}$. An increase in $l_{1}$ will raise the coefficient, whereas an increase in $a_{1}$ will lower the coefficient. Since the ratio $l_{1} / a_{1}$ is equivalent to the drainage density $D_{d}$, the

1 This statement is based on observations of L. B. Leopold (personal eommunication) as well as observatinas of the writer. 


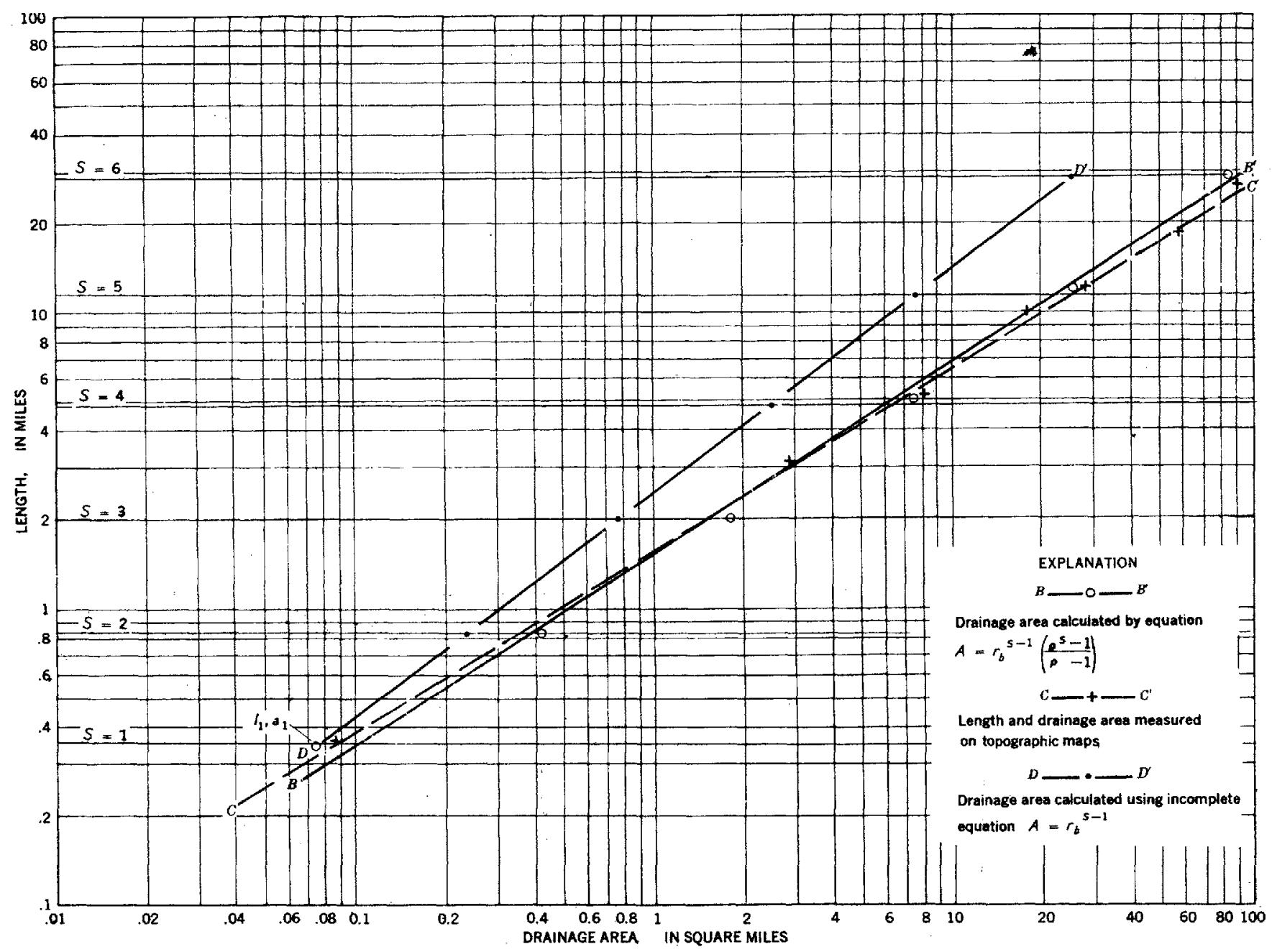

Frounk 26.-Graph comparing calculated and measured values of stream length and drainage area in the watershed of Christians Creek, Va. $B-B^{\prime}$, line connecting calculated values based on a Horton analysis of stream lengths and number. $C-C^{\prime}$, line connecting measured values. See text for explanation of line $D-D^{\prime}$.

coefficient must be a function of $D_{d}$.

The slope of the lines $B-B^{\prime}$ and $C-C^{\prime}$, or exponent, must be a function, on the other hand, of the ratio $r_{l} / r_{b}$ or Horton's $\rho$. This relation is more complex but its truth can be demonstrated. The values of $L$ for each stream order, as is shown in figure 26 , are multiples of the logarithm of the length ratio plus a constant $l_{1}$. Since the graph is on a logarithmic scale these points are evenly spaced. Similarly if $A_{s}$ were equal to $a_{1} r_{b}^{s-1}$ and the expression $\frac{\rho^{s}-1}{\rho-1}$ were omitted from consideration then the values of $A$ for each stream order would also be evenly spaced. The resulting line connecting the points relating $L$ to $A$ would be straight. Such a line has been drawn and is shown in figure 26 by the line $D-D^{\prime}$. The slope of this line is determined by the ratio $r_{l} / r_{b}$ and as would be expected from the data used to construct the figure, the line has a slope in this case of 0.75 .

The equation of the line $B-B^{\prime}$, however, is less simple, as it is modified by the expression $\frac{\rho^{x}-1}{p-1}$. But this expression is itself a function of $r_{l} / r_{b}$ since $\rho=\frac{r_{l}}{r_{b}}$ by definition. The slope of the line is therefore a function of the ratio $r_{l} / r_{b}$ (Horton's $\rho$ ). The coefficient is also affected by this ratio but only to a small degree.

The significance of this analysis is that it demonstrates that the overall shapes of drainage basins are geometrically related to the pattern of the drainage network. Since the profile of the stream is determined by the rate of increase of drainage area, among other factors, it must also be related to the geometry of the drainage network. We may surmise that this geometry is determined by many factors including relief, geology, elimate, and vegetation. The values of the factors defined by Horton in his stream geometry must have rather narrow limits in the northeastern United States, for the relation between length and area is obviously a conservative one over this region. 


\section{RELATION OF PARTICLE SIZE OF MATERIAL ON THE BED TO STREAM LENGTH}

It has been shown by figure 18 that in some individual streams there is a systematic relation between slope and particle size of bed material. The particle size may change from one reach of a stream to another, or it may remain the same for many miles of stream. These changes are abrupt in some cases but more commonly seem to be gradational, so that the rate of change of particle size in a downstream direction remains constant for long distances. The reasons for these changes are discussed later in the report (p. 74 to 87). The regularity of the changes as shown by figure 27 is rather surprising. In some streams, such as those in the Devonian sandstone area and the Calfpasture River, the particle size of the bed material is about the same in all reaches; in some, such as Gillis Falls, the size increases markedly downstream; in others, the size decreases.

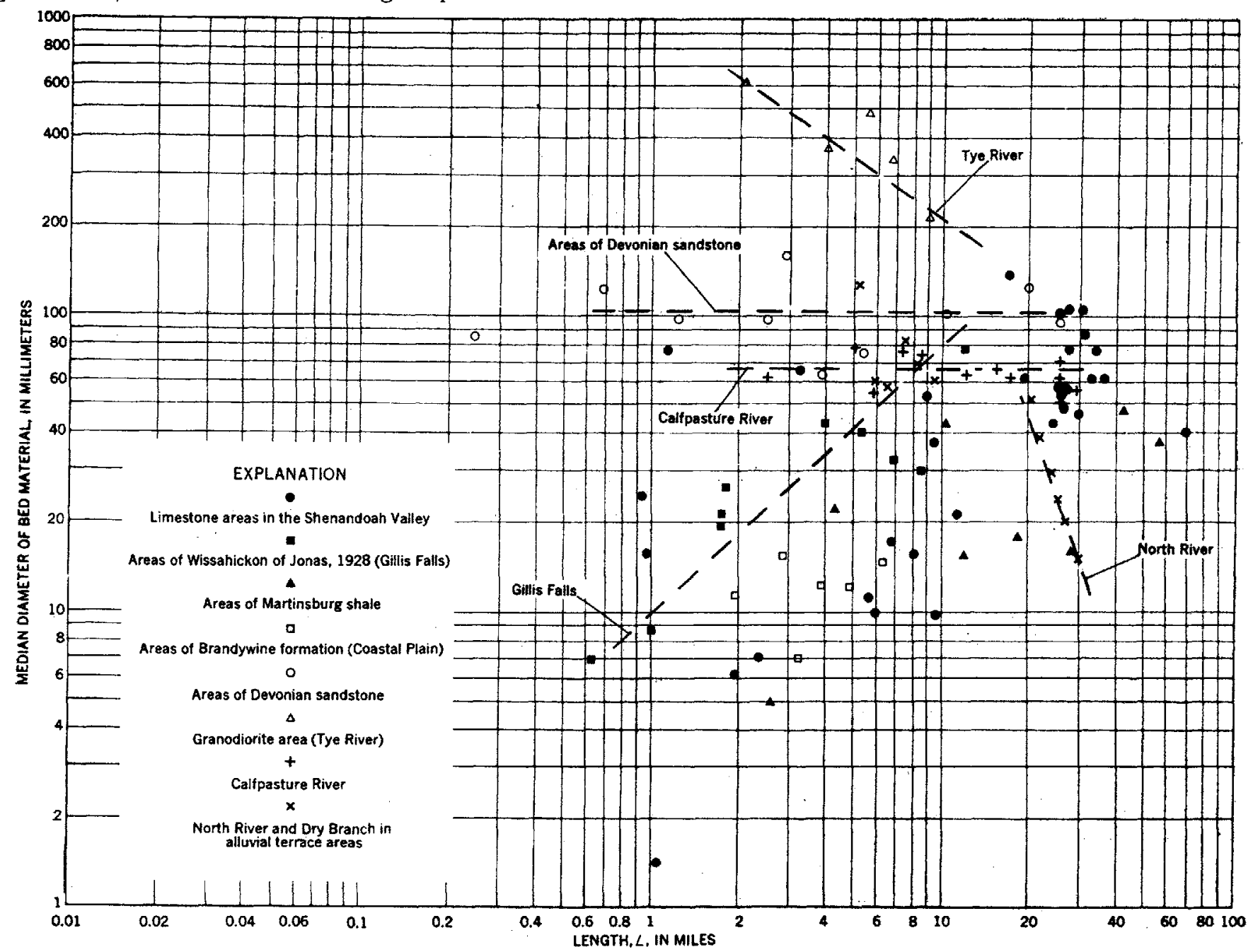

Figune 27.-Logarithmic scatter diagram showing the relation between length and median particle size of material on the strean bed at the measurement localities (table 8).

Probably the particle size of the bed material is closely related to geologic factors. It may change abruptly as geologic boundaries are crossed, but, in many streams, especially in reaches where the bedrock is the same, the change in size appears to be systematic. If the relation between particle size and length for such a stream or drainage basin is plotted on a double logarithmic scale, a straight line drawn through the points may be expressed by an equation of the form

$$
M=j L^{m},
$$

where $M$ is the median diameter of the bed material, $L$ is the stream length, and $j$ and $m$ are constants. ${ }^{2}$

Figure 28 is a graph showing the increase in particle

2 The constant $j$ is the value of the particle size at a stream length of 1 mile in terms of the measures used in this report); $m$ is the rate of change of particle size in a downstream direction defined as

$$
\frac{\log M_{1}-\log M_{2}}{\log L_{1}-\log L_{2}}
$$

and may be positive, negative, or, if grain size is constant, equal to zero. 


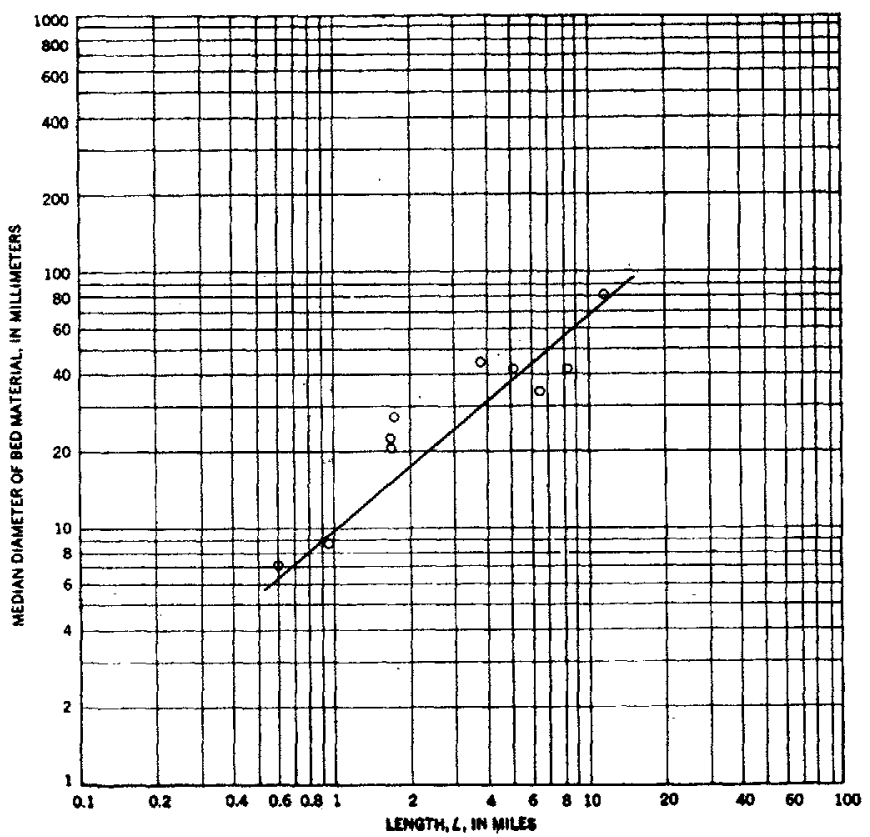

Frouk 28.-Logarithmie diagram ahowing the relation between particle sise of bed material and stream length in Gillis Falls, Md. size of bed material in the basin of the Gillis Falls creek. The line drawn through the points on this graph has the equation

$$
M=10 L^{(0.86)}
$$

\section{MATHRMATICAL EXPRESSION OF THE LONGITUDINAL PROFIIE AND ITS RELATION TO PARTICLE SIZE OF MATERIAL ON THE BED}

It was shown early in the discussion, on page 54 and by figure 16, that the slope and drainage area are related in such a way that the rate of change of slope as area increases appears to be constant for streams in the same geologic region. In other words, the paired values of slope and drainage area in geologically uniform regions, as plotted on logarithmic scales, appear in clusters that are very close to straight lines. This suggests that, since drainage area and stream length are interrelated in a regular manner, a plot of slope against length should result in a grouping of points similar to that of figure 16. Figure 29 is a graph showing this new relation. Since the localities on indi-

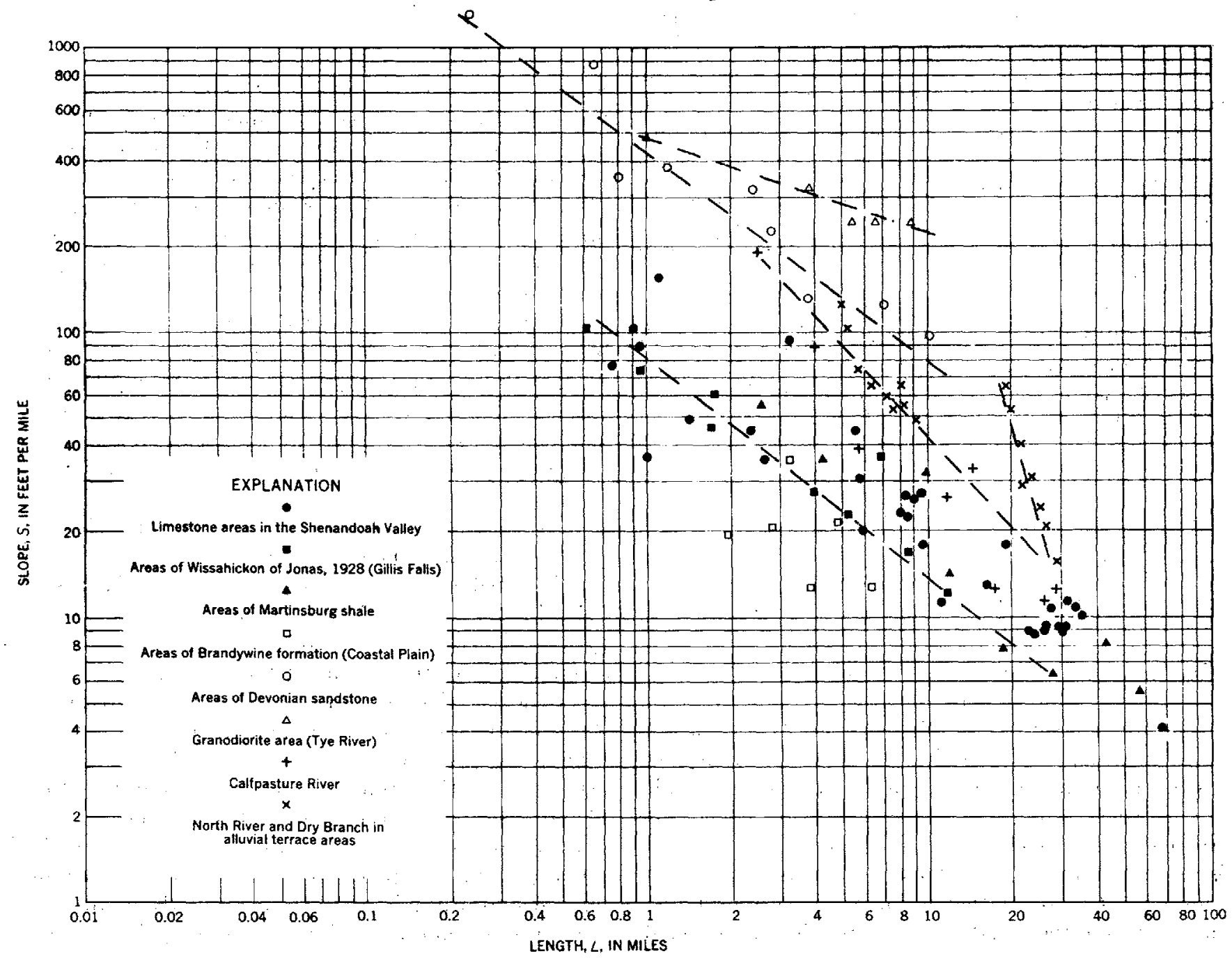

Frauas 29.-Logarithmic graph showing the relation between channel slope and channel length at the measurement localities (table 8). 
vidual streams and classes of streams are grouped closely about straight lines, the relation between slope and length on a stream may be expressed as a power function,

$$
S=k L^{n} \text {, }
$$

in which $S$ is channel slope at a point on the channel, $L$ is length as defined on page 47 and $k$ and $n$ are constants. The constants are very easily derived by plotting the data on channel slope and length on logarithmic graph paper. Two examples of graphs of this kind are shown in figure 44 .

When the length $L$ is unity on a line drawn through the points on such a graph, $\log L=0$ and $S=k$. Similarly when slope $S$ is unity (in our units, 1 foot per mile) $\log$ $S=0$ and $n=\log k / \log L$. The value of $L$ can be read from the graph by inspection and $n$ obtained by calculation. The value of $n$ is also equal to the tangent of the angle of the slope of the line through the points. Its value may therefore be approximated by measurement with a rule on graph paper provided that the logarithmic scales on the two coordinates are in equal divisions.

Large values of $k$ indicate steep channel slopes near the drainage divide, and small values indicate shallow slopes. Positive values of $n$ indicate convex (upward) profiles; and the larger the value of $n$, the greater the convexity. Negative values of $n$, on the other hand, indicate concave profiles, and large negative values of $n$ indicate pronounced coneavity. A zero value for $n$-that is, a horizontal line on the graph-indicates that the channel slopes uniformly without concavity or convexity.

Equation 9, relating channel slope and length, is a differential equation because the slope as measured in this study is a tangent to the profile. In other words it is a tangent to the curve that defines the relation between fall $H$ and length $L$, (see page 63). For this reason an expression for the long profile may be obtained by integration of equation 9 .

$$
\begin{aligned}
& \text { Since } \\
& \begin{aligned}
S & =k L^{n} \\
H & =k L^{n} d L \\
& =k \log _{e} L+C \text { where } n \text { equals }-1 \\
& =\frac{k}{n+1} L^{(n+1)}+C \text { where } n \text { does not equal }-1
\end{aligned}
\end{aligned}
$$

Many stream profiles bave been plotted by the writer and where the geology along the stream is fairly uniform are found to fit one or the other of these two equations very closely. Equation 10 is a straight line if plotted on semilogarithmic seales. Equation 11 is a straight line if plotted on full logarithmic scales where the value of the constant $C$ is close to zero. The writer has found this to be often true if the value of $n$ is between 0 and -1 . If, however, $C$ is other than zero, its value must be determined before the equation of the profile can be found.

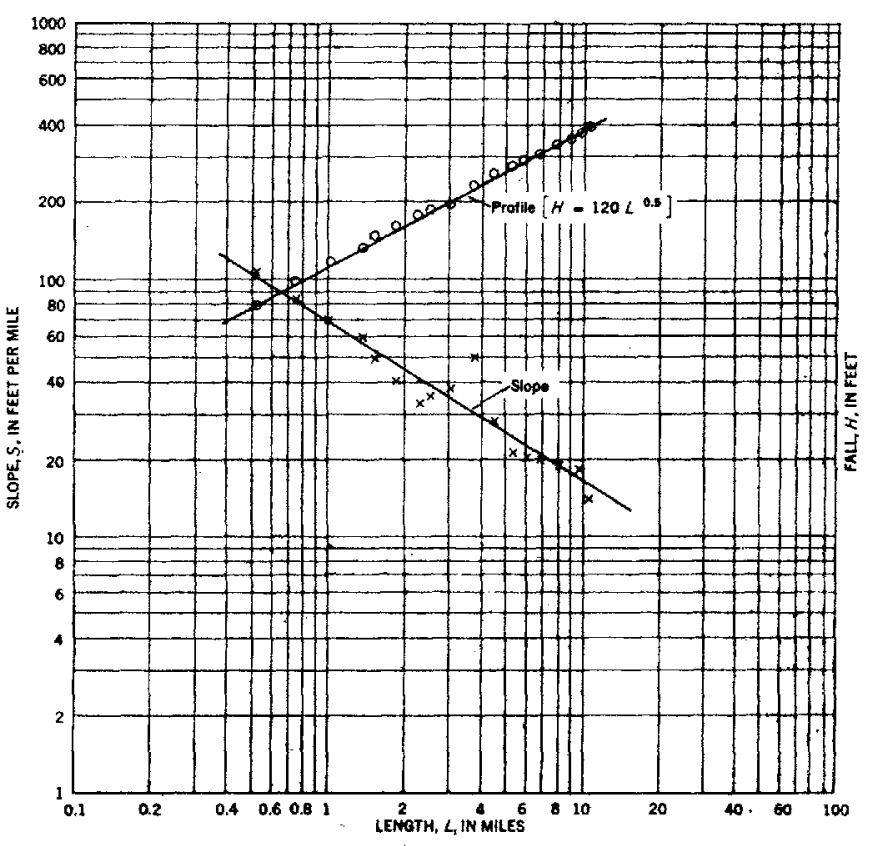

Figune 30.-Profile and relation between slope and length of points along Gillis Falls, Md. Data from Winfield and Woodbine quadrangles, Maryland, of U. S. Geological Survey, acale 1:24,000.

Simple methods of obtaining the constants for curves of these kinds are described by Lipka (1918, p. 128-145). Figure 30 is an example of a profile that fits equation 11 very closely. The graph shows both the profile and its first derivative, the channel slope. Since the graph is drawn so that all values are positive in sign the slope declines to the right whereas the fall rises to the right as length increases.

Equations 10 and 11 provide a family of curves that have a wide range in curvature and steepness, as shown in figures 31 and 32 . Figure 31 is a graph showing the curves of the equation $S=k L^{n}$ for various values of $k$ and $n$ in which, as in the streams studied, all the profiles are concave to the sky. The profiles that are the integrals of these equations are shown in figure 32 .

Note that in figure 32 the ordinate, or $H$ axis, is inverted, so that the fall increases downward. The figure is thus inverted only to place the profile in a familiar position.

Fitting the long profile to a curye that can be expressed by an equation is valuable principally because it permits a comparison of the heights of the streams and their terraces and permits comparisons of the profiles or parts of the profiles of two different streams, or their numerical expression by one or two constants. The mathematical expressions of the profile just described (equations 10 and 11) are easy to use, for the constants can be obtained from straight lines on ordinary logarithmic and semilogarithmic graph papers. Graphic representation of stream profiles on a semilogarithmic graph is particularly useful in the analysis of streams and will be discussed again on page 89 . 


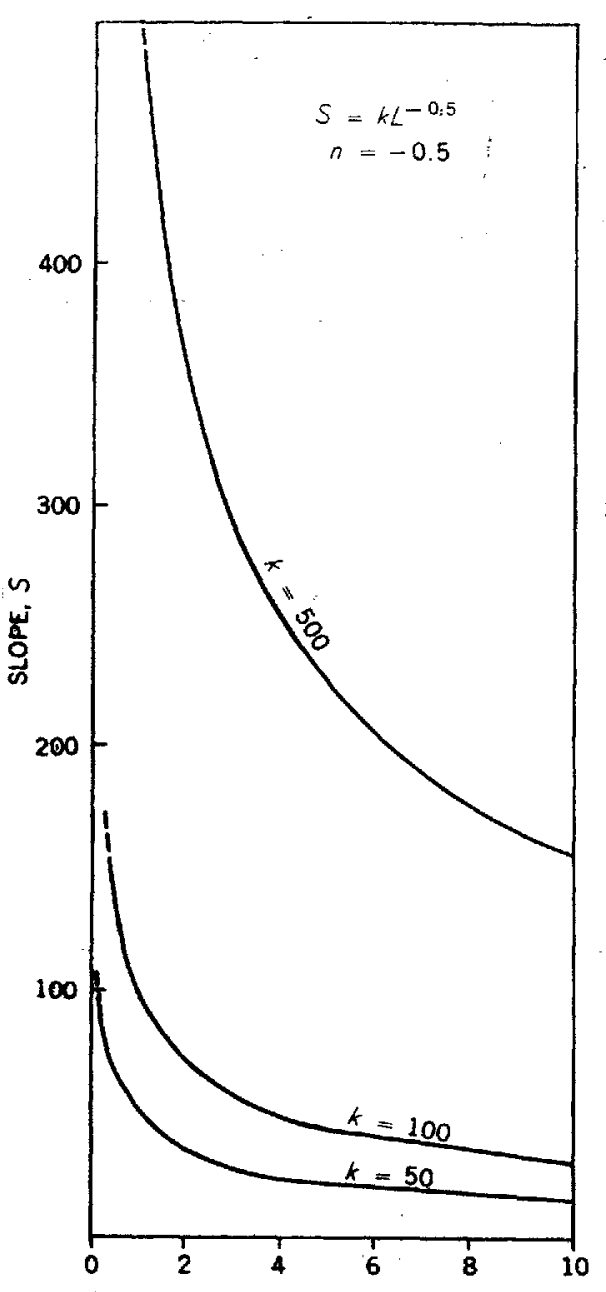

A

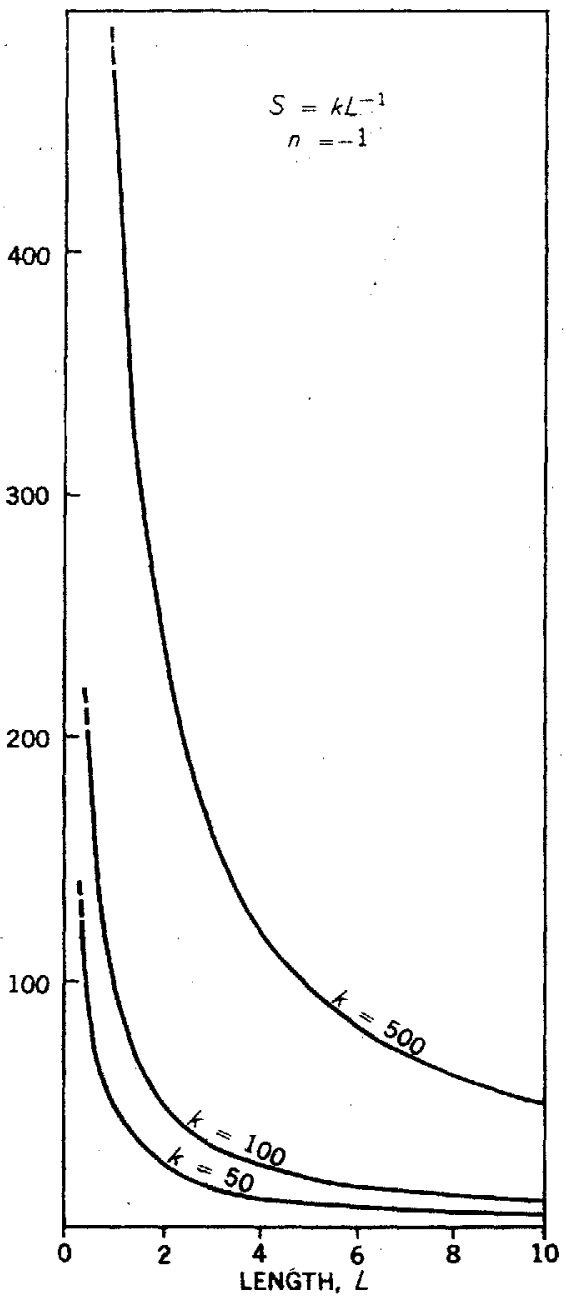

B

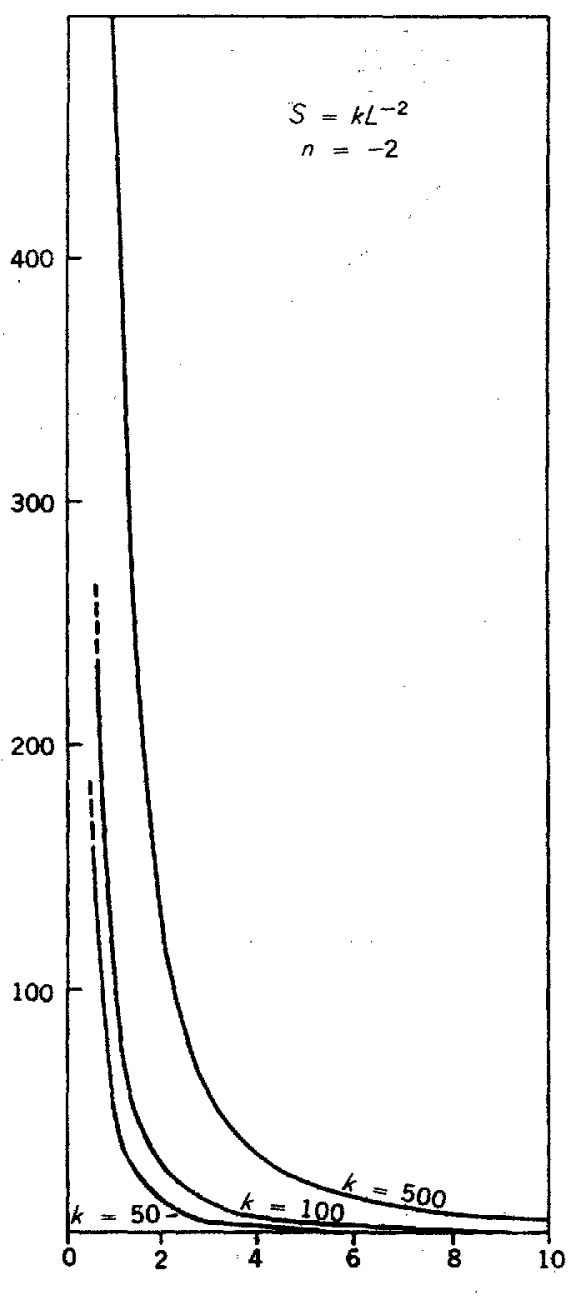

c

Fravre 31.- Graphs on arithmetic scales showing the relation between slope and length, where $S=k L^{n}$, for various values of $k$ and $n$.

Equations 10 and 11 fit many streams because channel slope decreases in a regular manner as discharge increases and, of course, because discharge and length are interdependent and increase proportionally. It has also been shown that particle-size of the bed material is another variable that determines the form of the profile and that changes along the stream either in a regular manner or abruptly. It is therefore of interest to consider the relation of particle-size changes to the two equations 10 and 11 . The analysis that follows shows that in the case of the streams studied in Maryland and Virginia, where particle size remains the same upstream and downstream, the long profile may be described by equation 10 . Where the particle size changes systematically in a downstream direction as a power function of length, the fall is no longer proportional to the logarithm of the length but follows equation 11 and is proportional to some power of the length.
From equations 2 and 3 an equation can be obtained relating slope to size of bed material and length, as follows: 른

Since

$$
S=18\left(\frac{M}{A}\right)^{0.6}=18 \frac{M^{0.6}}{A^{0.6}}
$$

and

$$
\begin{aligned}
& L=1.4 A^{0.6}, \\
& S=25 \frac{M^{0.6}}{L}
\end{aligned}
$$

where $S$ is slope in feet per mile, $M$ is median particle size of bed material in millimeters, and $L$ is length in miles (distance from source to the locality). A plot of the paired values of $S$ and the ratio $M^{0.6} / L$ on a scatter diagram produces a field of points comparable with that of equation 2 , shown in figure 19.

As shown on page 68 and equation 8 , the variables $M$ and $L$ appear commonly to be systematically related. 


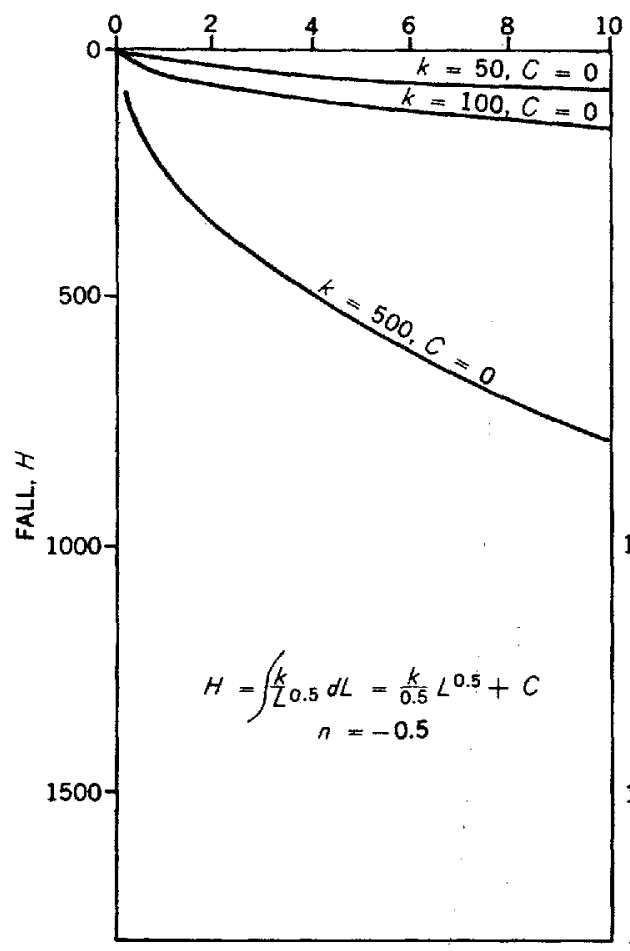

A

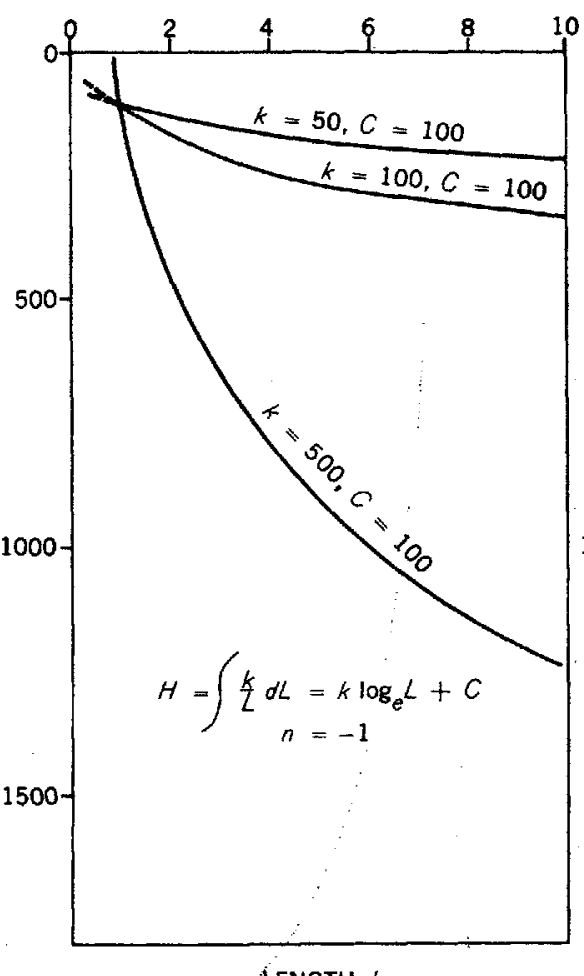

LENGTH, $L$

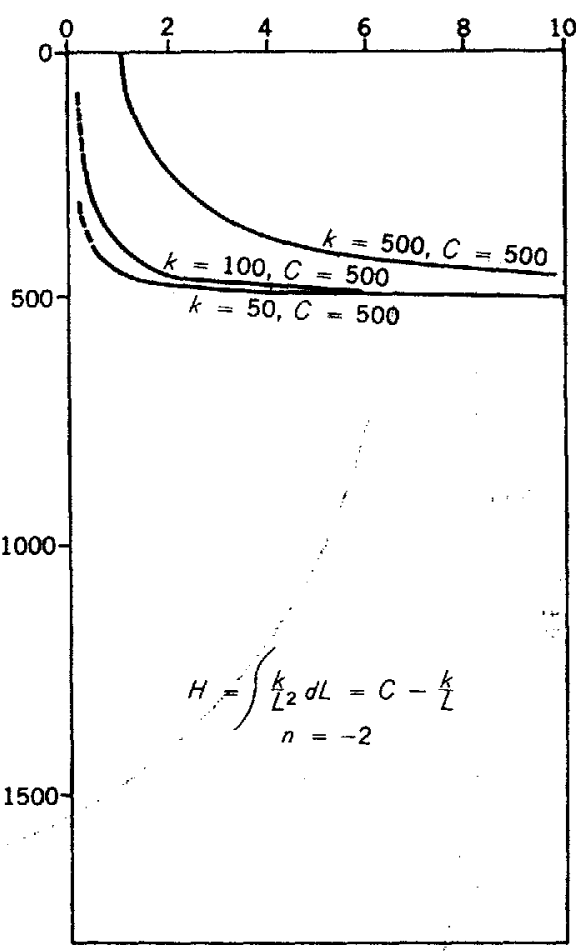

C

Fiovrs 32.-Graphs on arithmetic scales showing the longitudinal profiles obtained by integration of the curves of figure 31 . The values of the constant of integration $C$ are chosen arbitrarily.

The values of the constants in equation 8 may therefore be substituted in equation 12 and a general equation relating slope to length is obtained, in which

$$
S=25 j^{0.6} L^{0.6 m-1}
$$

where $S$ is slope, $L$ is length and $j$ and $m$ are constants related to the rate of change of particle size in a downstream direction in a single stream. This relation should be valid for all streams or reaches of stream where changes in particle size are regular and where other relations such as length to area and width to depth also are regular. Like equation 9, equation. 13 can be integrated to give a relation between the fall, $H$, and the length, $L$, so that

$$
\begin{aligned}
H & =25 j^{0.6} \log _{e} L+C, \text { where } m \text { equals } 0 \\
& =\frac{25 j^{0.6}}{0.6 m} L^{0.6 m}+C, \text { where } m \text { does not equal } 0
\end{aligned}
$$

The constant $C$ is the constant of integration and determines the position of the curve with respect to the coordinates. Thus the profile may be expressed by two equations, one a logarithmic equation like equation 10 and the other a power equation like equation 11 . The logarithmic equation applies when the constant $m$ is zero. This occurs where $M=j$ in equation 8 , where there is no change in particle size in a downstreatm direction.
To test how closely these equations fit longitudinal profiles, four streams are selected from those included in table 8 and shown on figure 11. These include the Calf-

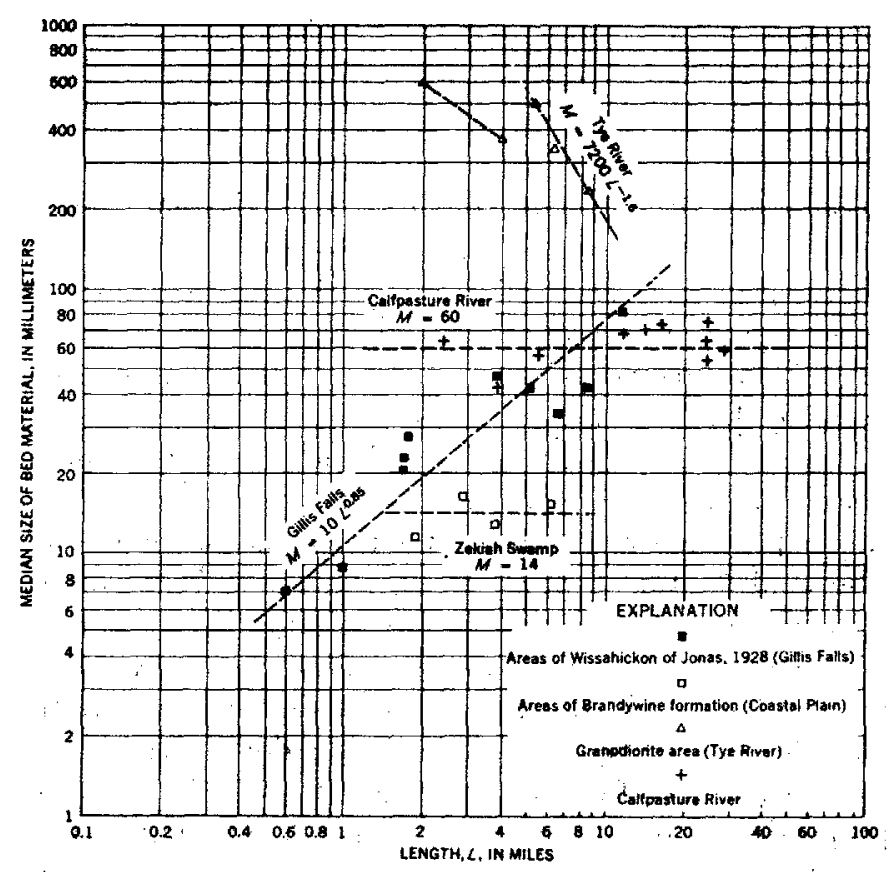

Fratre 33.-Logarithmic graph showing the relation between median size of bed material and stream length for four streams in geologically difierent areas. 
pasture River, Zekiah Swamp, Gillis Falls, and the Tye River, streams which are widely separated geographically in areas that are very different geologically. Data on particle size are available at only a few places on these streams and it is enly on the Calfpasture River and Gillis Falls that the information is sufficient to give a real picture of the downstream changes in particle size. The relation between particle size and length in terms of equation 8 is shown for the four streams in figure 33 . From this diagram the values for $j$ and $m$ are obtained as shown in table 2. By substituting these values in equations 14 and 15 four equations are obtained, which are compared in table 3 with the equations obtained by use of actual elevations of points in the streams.

TABLE 2.-Values of the constants $\mathrm{j}$ and $\mathrm{m}$ for four streams

\begin{tabular}{c|c|c}
\hline Stream & $j$ & \multicolumn{1}{|c|}{$m$} \\
\hline Tye River & & \\
Calfpasture River & 6,200 & -1.6 \\
Gillis Falls & 60 & 0.0 \\
Butlers Branch (Zekiah Swamp) & 10 & 0.85 \\
\end{tabular}

TABLE 3.-Comparison of profile equations computed from data on size of material on the bed with profile equations computed from actual elevations in the streams

\begin{tabular}{l|r|r}
\hline Stream & $\begin{array}{c}\text { Value of } H \\
\text { computed from } \\
\text { size data }\end{array}$ & $\begin{array}{r}\text { Approximate value } \\
\text { of } H \text { computed from } \\
\text { actual elevations }\end{array}$ \\
\hline Tye River & $\mathrm{C}-5,200 L^{-0.96}$ & $20,000-17,000 L^{-0.9}$ \\
Calfpasture River & $290 \log _{e} L+C$ & $300 \log _{e} L+1,500$ \\
Gillis Falls. & $80 L^{0.6}+C$ & $122 L^{0.5}$ \\
Butlers Branch..... & $122 \log _{e} L+C$ & $60 \log _{e} L$ \\
\hline
\end{tabular}

In figure 34 the curves represented by the equations based on particle size are compared with the actual elevations of points on the streams. The values of the constant $C$ were obtained simply by fitting one point on the predicted curve to one point on the actual curve, so that the two could be compared. Agreement is far from perfect but nonetheless the data show that using information on particle size only and its position in the channel with respect to the source of the stream, it is possible to derive a curve that approximates the profile of the stream. Close agreement of the actual elevations with the predicted values could hardly be expected since we knew at the outset that variables other than particle size, length, and slope are involved in the problem.

It is particularly significant that an equation of logarithmic form such as equations 10 and 14 should fit streams
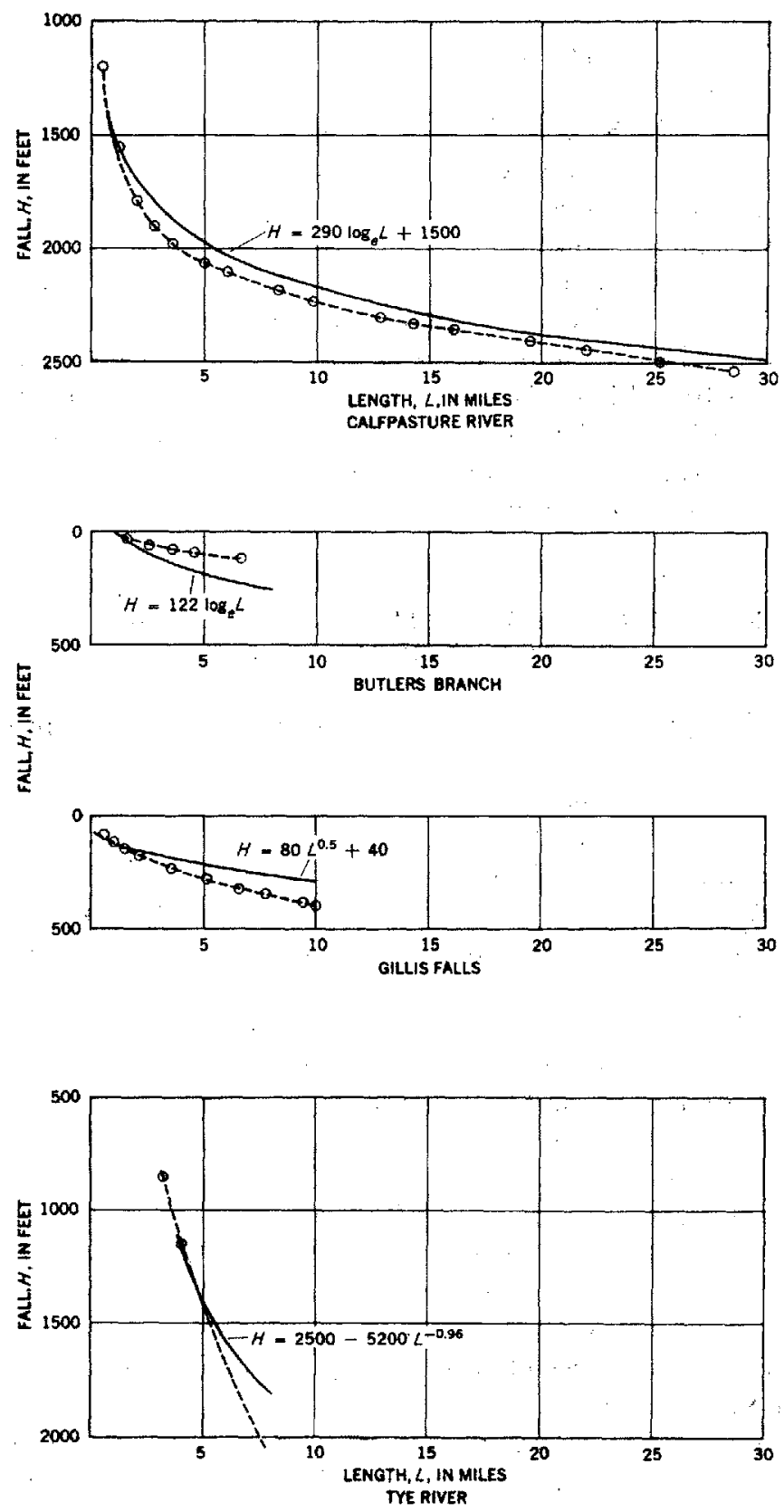

Fradre 34.-Comparison of profiles computed from the data in figure 33 with the actual profiles of the four streams. Data are from topographic maps.

like the Calfpasture River which show no change in particle size in a downstream direction. This must follow from the relation defined by equation 12 , for when the particle size is constant the slope is inversely proportional to the length $(S=k / L)$. Examples of logarithmic curves plotted on an arithmetic scale are shown in figure $32 B$. Where particle size increases in a downstream direction the constant $m$ must be positive in sign and the profile must have a low rate of curvature (or in other words is flattish) as exemplified by one of the curves shown in 
figure $32 A$. If the rate of increase in particle size is large enough, the profile is a straight line or may even be convex upward. This occurs where the value of the constant $m$ in equation 8 exceeds 1.66 . If the particle size decreases in a downstream direction, the constant $m$ must be negative and the profile must be highly curved, as is, for example, one of the curves shown in figure $32 C$.

It should perhaps be emphasized that equations 14 and 15 involving size of bed material are not useful as a means of defining stream profiles or of comparing them and equations 10 and 11 or some expression derived from them are to be preferred. This is simply because the line representing the stream profile on a graph is most readily defined by an equation involving two variables and not three.

\section{MATHEMATICAL EXPRESSION IN PREVIOUS WORK ON LONGITUDINAL PROFILES}

The problem of expressing the longitudinal stream profile in the form of an equation has been widely studied. Apparently it has been thought by some that a form of expression which closely described the profile of many streams would in itself be indicative of the relations between the factors that determine the profile. The problem is not a simple one and many equations of various forms have been devised, based on different concepts of stream equilibrium, which fit the profiles of some streams quite closely. Nevertheless a mathematical model or expression deseribing the profile is not only desirable but may be necessary in order to make comparisons between streams or between parts of a single stream.

The literature dealing with longitudinal profiles has been summarized recently by Woodford (1951). In general the formulae expressing the profile have been of two kinds. The first is based on the theory of Sternberg (discussed by Schoklitsch, 1933, and Woodford, 1951, p. 813) that the weight of pebbles making up the bed load decreases exponentially in a downstream direction as a function of wear. It is presumed that the slope is proportional to a function of particle size of the bed load and must decrease exponentially in a downstream direction. The graphic representation of the profile in this kind of equation is a straight line on semilogarithmic graph paper, but it is quite different in form from the semilogarithmic relation used here (equation 10). Distance is plotted on the arithmetic scale, and elevation or fall on the logarithmic scale. The most recent use known to the writer of this kind of equation is by Shulits (1942).

The second common form of a profile equation is probably based on Gilbert's law of declivities (Gilbert, 1877). This is a logarithmic equation related to logarithmic equation 10 used here. Jones (1924) used such an equation in a study of the terraces of the Towy River. The logar- ithmic equation is also a straight line on semilogarithmic graph paper but the coordinates are reversed.

Equations such as 10 and 11, suggested herein to describe the longitudinal profile, are not necessarily superior to the others nor do they fit all of the data better. They have the advantage of simplicity and the fact that the zero point of the coordinate system is the source of the stream, which permits comparisons to be made between streams on the basis of relative drainage area or length.

\section{ORIGIN AND COMPOSITION OF STREAM-BED MATERIAL}

Some of the factors that determine the steepness of the long profiles of natural streams have been considered. It has been shown that particle size of bed material is one of the most important of these in causing characteristic differences between streams, and that particle size is dependent on the rocks of the region in which the stream originates and through which it flows. It is now important to learn how the source rocks of the region are related to particle size of bed material at the point where the material enters the stream, and what factors are involved in the changes of size from one reach of a stream to another.

Studies of the lithologic composition and size of the bed material, which were made at many of the localities along the Middle River, along East Dry Branch, and in Gillis Falls, are discussed in the following pages. By the grid method of size distribution analysis used in this study, each size class was subdivided according to lithologic composition. Therefore, in areas where the bed material contains boulders of several kinds of rock with contrasting physical properties, it has been possible to subdivide the samples into lithologic components and to estimate the median sizes of each component. This required counts of from 170 to 500 pebbles and boulders at each locality. General observations concerning the composition and origin of bed material were made in all the streams.

The data on the composition of the bed material, though crude, show that the bed material of these streams is composed in part of detritus that has been transported from upstream and is still in transit, and in part of material that is a sort of lag concentrate which collects near its source. The latter is probably moved only in rare floods of great violence. It remains in the bed near its source to be broken and scoured by impacts of the moving load until it is reduced to sizes that can be transported in floods of greater frequency. The lag material on the bed is therefore the coarsest fraction of the total load. The data further suggest that the topography along the stream, a function of the relief, is itself an important factor determining the size. The physical properties of the bed material are important factors, for they determine the rate at which accumulations of detritus can be broken or worn down and then transported. 


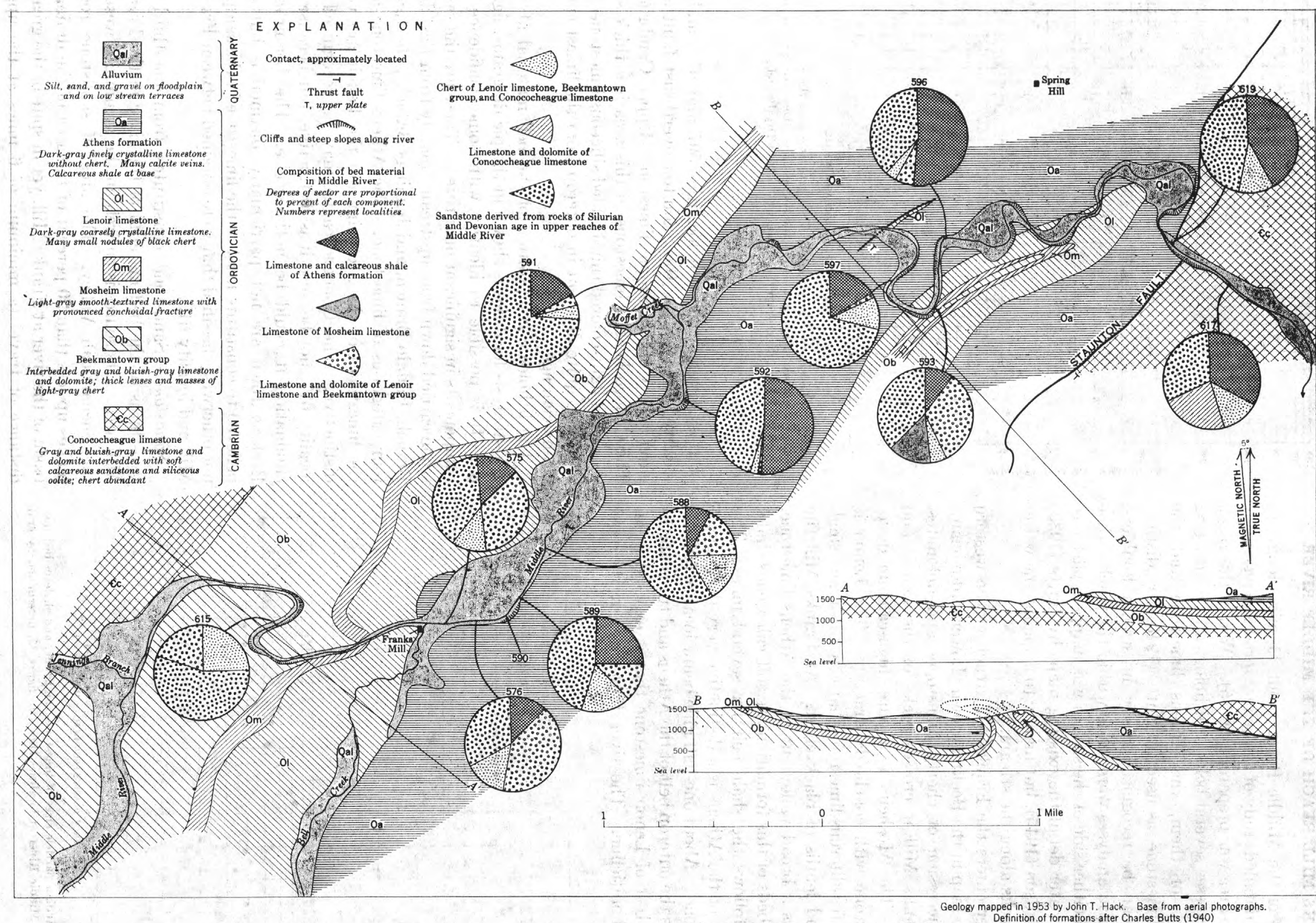

FIGURE 35.-Map of Franks Mill reach of Middle River showing the lithologic composition of the bed material in percent of the total sample at measurement locali-

ties. Whole circle represents 100 percent; degrees of sector are proportional to percent of each component. 
FRANKS MILL REACH OF THE MIDDLE RIVER

A reach of the Middle River about 11 miles long was chosen for detailed study of the bed material and a geologic map of the area was prepared (fig. 35). Within this reach the river crosses several belts of lithologically contrasting rock. Two of them, the Athens limestone and the Mosheim limestone, as used by Butts (1940), are distinctive and can be recognized easily in stream boulders. Fourteen grid analyses were made within the reach. The geology on either side of the stream was mapped, partly to bring to greater detail the existing maps by Butts (1933) and Edmundson (1945), but mainly to acquaint the writer with the rocks along the stream.

The river enters the Franks Mill reach at the western edge of the map in the Beekmantown (Lower Ordovician), a thick succession of cherty limestones and dolomites. Above Franks Mill it crosses rocks of the Lenoir and Mosheim. The Mosheim is a pure, high-calcium dovegray limestone with conchoidal fracture. The Lenoir is a massive, fossiliferous limestone that contains many small patches and lentils of black chert. At Franks Mill the river enters a broad valley cut in the Athens limestone. The basal beds of this formation are soft calcareous shale; the river follows the shale belt for several miles. The upper part of the Athens is a distinctive very dark chertfree limestone. About one-half mile below locality 597 the river leaves the outcrop belt of the Athens and turns northward in a belt of Lenoir limestone that is exposed in an overturned anticline. The river flows around the nose

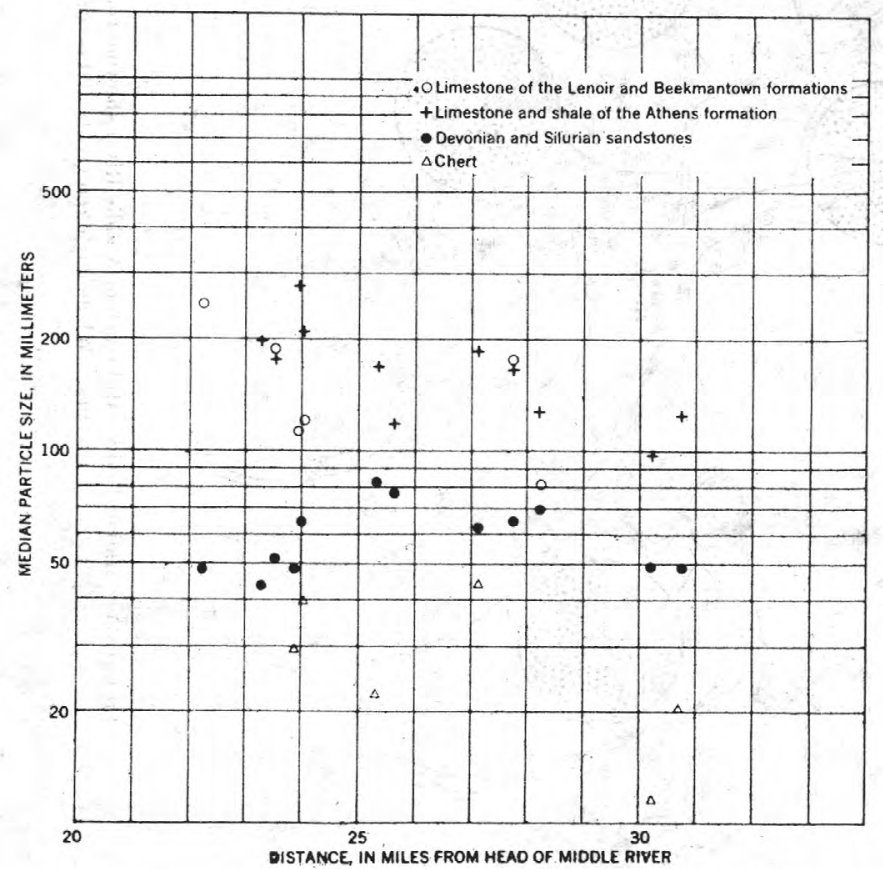

Frgure 36.-Median particle sizes of limestone, sandstone, and shale in bed material in the Middle River at localities shown in figure 35 , determined by grid analyses.

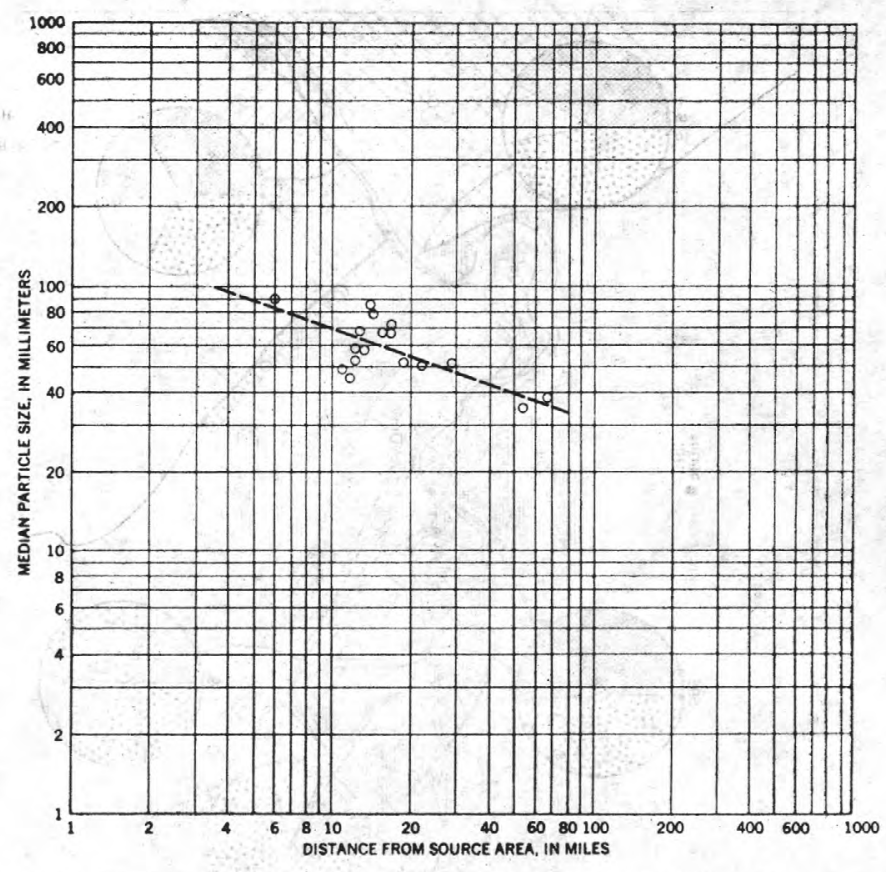

Figure 37.-Logarithmic graph showing the rate at which the sandstone component decreases in size away from the source area. Distances are measured along the Middle River from the source area in East Dry Branch.

of this anticline between localities 597 and 619 , and at locality 619 it crosses the Staunton overthrust fault and enters the Conococheague limestone (Upper Cambrian). The Conococheague limestone in this area is a thick succession of light-colored thin-bedded siliceous limestone and dolomite, quite different in outerop from the limestone of Ordovician age.

The lithologic composition of the bed material at the grid-analysis localities is shown in the pie diagrams, figure 35. It is possible to identify with some confidence six components in significant quantities. These are the sandstone carried down from upstream (mainly from East Dry Branch, Buffalo Branch, and Jennings Branch), chert, and four categories of limestone. The Athens limestone and the limestones of the Mosheim and the Lenoir are very distinctive. The Conococheague may be recognized at locality 617 , not because it is distinctive, but because by elimination it could be nothing else. The Lenoir and Beekmantown are not particularly distinctive but are believed to constitute most of the limestone in the samples. not otherwise classified that were obtained between Franks. Mill and locality 619 .

Sandstone.-Sandstone constitutes from one-third to two-thirds of the bed material of the river in the Franks Mill area. Its source is entirely in the mountains west of the Shenandoah Valley. The area of sandstone rocks. makes up less than 20 percent of the area of the drainage basin of the river at Franks Mill, yet in spite of the greater distance of travel (a minimum of 6 miles at the upper 
end of the reach) the sandstone is in general the dominant constituent of the bed material.

The median diameter of the sandstone component ranges from 44 to 85 millimeters, averaging around 60 millimeters, as shown in figure 36. Several sandstone boulders over 250 millimeters in diameter were seen.

The percentage of sandstone in the samples within the reach shown in figure 35 is inversely related to the abundance of other constituents. The median size of the sandstone component cannot be shown to change systematically within the area of figure 35 , but, considering all the localities within the limestone region along the Middle River, the sandstone apparently (fig. 37) decreases gradually in size from over 100 millimeters in median diameter to less than 40 millimeters after 65 miles of travel in the stream.

The decrease in size or weight of bed material with distance from the source area has generally been expressed as an exponential curve (Schoklitsch, 1933; Pettijohn, 1948, p. 397). The data obtained in this study are insufficient to have any critical bearing on earlier studies relating to the rate of abrasion but are not out of accord with them.

Chert.-Chert is present in nearly all the samples. In fact, it is ubiquitous in nearly all stream channels in the limestone region. In the Franks Mill area the chert must originate above Franks Mill, because none has been found in the Athens limestone. At locality 615 , within the outcrop area of the chert-rich Beekmantown dolomite, chert makes up 25 percent of the bed material. In the Athens limestone area it declines to about 3 percent at locality 592 .

In all the samples chert is the finest constituent. Its actual median size is probably smaller than the median sizes given in figure 36 , because the samples, which were subdivided according to lithologic composition, include only material coarser than 10 millimeters. Sandstone and limestone are major constituents of the coarse fractions; omission of the fine fraction from the pebble count has little effect on the median size of rocks of these kinds, as obtained from the count. Chert, however, is present in only the small fractions but is locally their dominant constituent; omission of the fine fraction undoubtedly results in an exaggerated value for the median size of chert as obtained in the count (fig. 36). Probably the median diameter of the chert averages between 5 and 10 millimeters for the reach. This estimate is based on 3 counts of fine fractions that were divided into size classes by sieving and subdivided into lithologic components by examination under a binocular microscope.

The chert, like the sandstone, is present in the load throughout the Franks Mill area. It travels through reaches where there is no local source and is therefore a resistant as well as persistent component. The chert fragments are small, partly because the chert occurs in the limestone in small irregular masses or nodules, or in thin stringers which, when released from the enclosing rock by solution, abrasion, or breakage, are capable of forming only small fragments. Although very hard, the chert is generally weakened by many fractures and by veinlets of calcium carbonate.

Limestone.-The limestone ranges from about 10 percent to more than $\mathbf{5 0}$ percent of the bed material in this region. The many changes that take place within short distances in the kind, amount, and size of limestone fragments are very revealing. At locality 615 limestone, mostly Lenoir and Beekmantown, makes up 18 percent of the sample. Some Conococheague limestone may be present. Below Franks Mill the limestone has increased at locality 575 to 60 percent of the sample and most of this is Lenoir and Beekmantown, transported from above Franks Mill. Probably considerable limestone has been added in the narrow gorge above the mill. The small amount of Athens limestone at locality $\mathbf{5 7 5}$ could have gotten into the stream only by plucking from the bed, for there are no Athens outcrops on either side of the channel, whereas there are two riffles floored by Athens immediately above the locality.

The next significant change is at locality 589 , where the Athens has increased to 26 percent. This locality is below a cliff of Athens limestone now being undercut by the stream at a bend (described on p. 79). No Athens outcrops are exposed immediately below this locality, and at locality 588 the proportion of Athens limestone in the bed material has dropped to 8 percent. The river again impinges against a cliff or steep slope of Athens limestone about 0.5 mile below locality 588 and also at locality 592 (described in detail on p. 79). Here the Athens constitutes 50 percent of the bed material, but 0.4 mile farther, after a passage between banks composed entirely of alluvium, the Athens makes up only 17 percent. It is noteworthy that the count of Athens limestone at this place contained pebbles that were reddened and weathered.

In this area, only 2.6 miles from the last Lenoir outcrop along the channel, the Lenoir and Beekmantown have dropped in amount from 47 percent to less than 5 percent. Downstream from this point the Athens limestone continues to fluctuate in percentage of the sample. The fluctuations are obviously related to the proximity of outcrops of Athens along the channel. At locality 593, the river impinges for a short distance against a rocky slope of the Mosheim member of the Lenoir limestone. At this place the Mosheim constitutes 15 percent of the bed material. Three-tenths mile beyond, below a long rocky slope of Athens, the Mosheim has been so reduced in amount that it makes up less than 1 percent of the sample.

Between localities 619 and 617 , less than 0.5 mile farther, the river crosses the Staunton fault. The Athens limestone component drops from 42 to 32 percent of the 


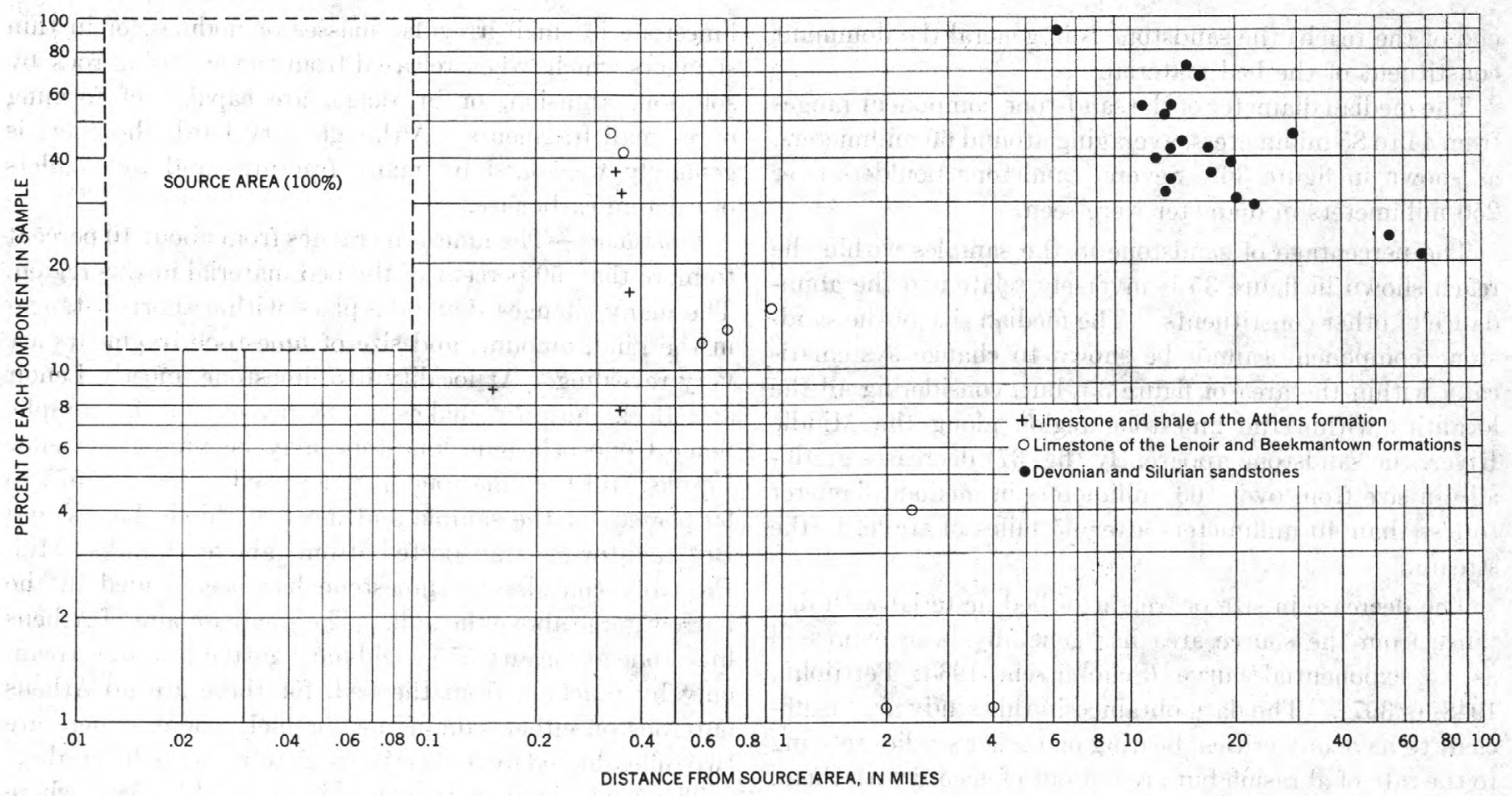

Figure 38.-Logarithmic graph showing the relation between distance of travel from the nearest source area and the percentage of three lithologic components of the bed material. The data include only localities along the Middle River.

bed material and the Conococheague limestone, an entirely new component, rises to 24 percent.

The sharp changes in the amount of different kinds of bed material are summarized in figure 38 . In this graph the sandstone includes localities outside the Franks Mill area on the Middle River. The sandstone travels long distances from its source, and even after 60 miles of travel in the Middle River through a limestone area it makes up a large part of the sample. At this distance the sandstone source area is only 10 percent of the total drainage area. Limestone from the Lenoir and Beekmantown formations persist in the Franks Mill area for a distance of only about 5 miles below the source area, whereas the Athens ceases to be an appreciable part of the bed material in less than 1 mile of travel.

The median size of the limestone fragments in every sample is considerably coarser than the sandstone, as shown in figure 36. Differences between the Athens and the Lenoir and Beekmantown may not be significant, but the coarsest samples are of Athens limestone, the least resistant component. Variations in size of the limestone fragments within the Franks Mill area do not seem to be systematic. If there are such variations, the data are not sufficient to reveal it. As will be shown by additional evidence in the pages following, the size of the boulders in the bed must be closely related to the distance from the source. The limestone boulders are large because they are near their point of origin, where they were torn from a steep slope or cliff by the lateral cutting of the stream. These blocks do not travel as part of the bed load but are destroyed or worn down within a short distance from the source.

It is probably the susceptibility of the limestone to breakage and abrasion that causes its rapid disappearance, rather than its solubility. Solubility, however, may be a minor factor. During the summer season, calcareous tufa forms on the stream bed at riffles in the Middle River, indicating that for at least a part of the year solution is not even a minor factor. As similar changes in the lithology of the bed material within short distances also occur in rocks that are not soluble in water (like the phyllite of Gillis Falls, p. 85) presumably solution is not a necessary factor. Solution along joint planes and fractures, however, may help to weaken the rock and facilitate breakage, and it may operate to some extent during high-water periods.

Abrasion, like solution, must also be a factor in reducing the bed material to small sizes. No data, however, are at hand by which to evaluate the importance of this factor. Since well-rounded fragments are abundant in the fine fractions of all the samples, and are present in even the coarse fractions, presumably abrasion is an important factor. Considerable study has been given this problem by others and it has been demonstrated that lithologic composition is an important factor determining the rate of wear of stream boulders and gravel (Schoklitsch, 1936). 
Description of locality 590.-Detailed notes were made at the first sharp bend in the Middle River below Franks Mill. This locality shows that lateral migration of the stream is an important source of "bed material, and that the products of erosion by the river"accumulate at the

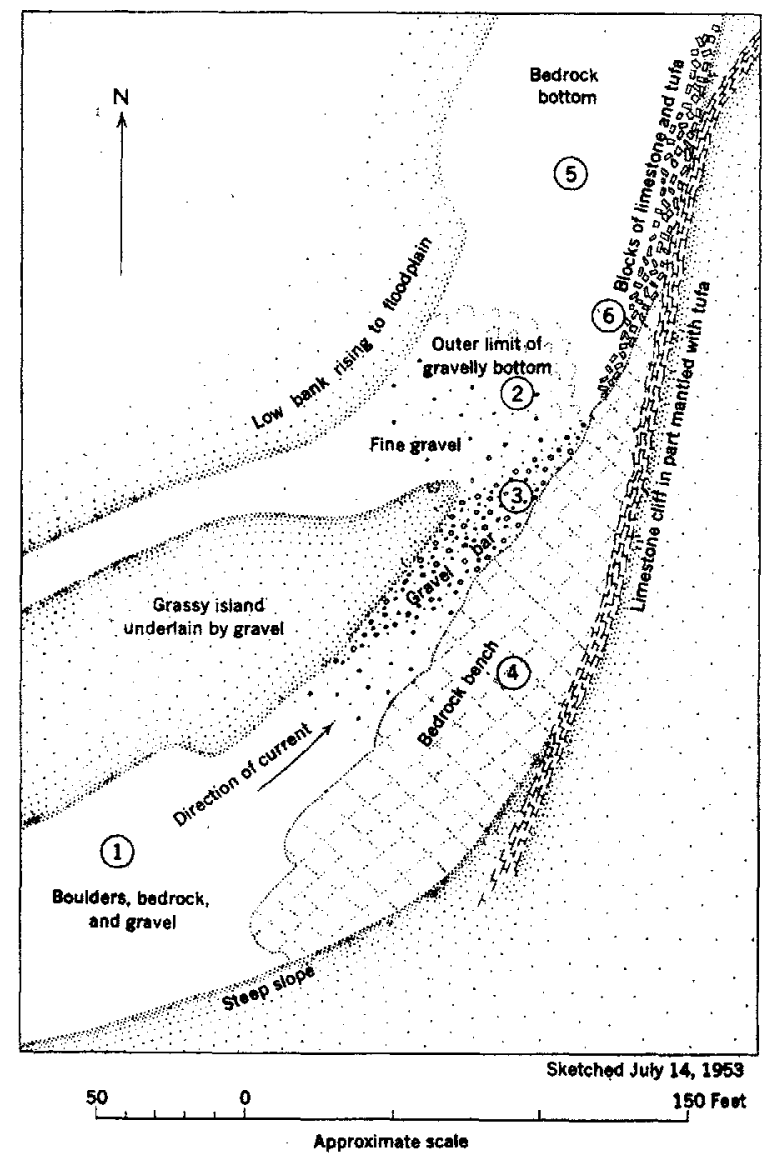

Fiavem 39.-Sketch map of a bend of Middle River at locality 590 below Franks Mill. See text for explanation of numbers in ciroles.

source. At locality 590 (fig. 39) the river flows against a bare ledge of Athens limestone and is diverted from a course down the dip to a course parallel to the strike. The stream length at this locality is $\mathbf{2 5}$ miles and average annual discharge is estimated at 150 second feet. Figure 39 is a sketch of locality 590 that shows the distribution of bottom materials in the channel. Upstream from the bend (area 1) the stream is floored by large boulders and gravel that have a median particle size of about 100 millimeters. At the cliff itself the bedrock is stripped off the eastern half of the channel and a bedrock bench (area 4), with only a few inches of water over it at low-water season, extends to a rocky overhanging cliff. West of the bedrock bench is a riffle over a gravel bar (area 3). The gravel bar is composed dominantly of sandstone pebbles carried down from upstream localities and has a median particle size of
60 millimeters. The gravel is swept off the rock bench (area 4) on which remain only a few large slabs of limestone that have fallen from the cliff. The cliff is partly of fresh limestone, but it is partly covered by a thick mantle of calcareous tufa deposited by water percolating downward from the slope above. A small delta of sand and fine gravel (area 2) is immediately below the bar. Downstream from the bar and the bedrock bench, the bed of the stream is mostly floored by bedrock (area 5). At area 6, immediately under the overhanging cliff, is an accumulation of coarse blocks of limestone and tufa that have been dislodged partly from the eliff itself and partly from the rock bench. Some boulders which are in this blocky accumulation of debris were probably derived by mass wasting from the slope above. Data on the size and amount of this accumulation of debris are given in table 4. The tufa, though fragile, breaks up in larger blocks than the limestone. It is only occasionally encountered as pebbles in the stream, indicating that it is not generally transported very far but is broken up or dissolved near the place where it has accumulated. Probably the fragility of the travertine favors the breakup in large fragments. It lies in the stream as a lag until broken up by movements of the bed material in floods.

TABLE 4.-Parameters oblained by grid analyses, showing size and amount of boulders of tufa and limestone in the accumulation downstream from the cliff of figure 39

\begin{tabular}{c|r|r|r|r|r}
\hline Material & $\begin{array}{r}\text { Median size } \\
\text { (millimeters) }\end{array}$ & $\begin{array}{c}Q_{1} \\
\text { (millimeters) }\end{array}$ & $\begin{array}{c}Q_{1} \\
\text { (millimeters) }\end{array}$ & $S_{0}$ & $\begin{array}{c}\text { Amount } \\
\text { (percent) }\end{array}$ \\
\hline Limestone & 150 & 280 & 68 & 2 & 60 \\
Tufa & 500 & 1,000 & 270 & 2 & 40 \\
Entire accumu- & & & & & \\
lation.... & 200 & 550 & 78 & 2.7 & 100 \\
\hline
\end{tabular}

Locality 592.-This locality is at another bend in the Middle River in the Athens limestone where the river again turns from a direction down dip to a direction parallel to the strike. No cliff is formed by the cutting of the river, but instead a steep rocky slope is maintained by the work of the stream at its base and mass movement of coarse limestone blocks. Conditions at the locality show that the coarse limestone boulders have accumulated directly under their source as at locality 590. A total count of 500 pebbles and boulders was made here, some of which were over a meter in diameter. Median particle size of the whole sample was 110 millimeters. Lateral changes on the bed were estimated by dividing the total count into 10 subsamples spaced at even intervals across the channel. Variations in median size and percent of the two principal lithologic components in the subsamples 

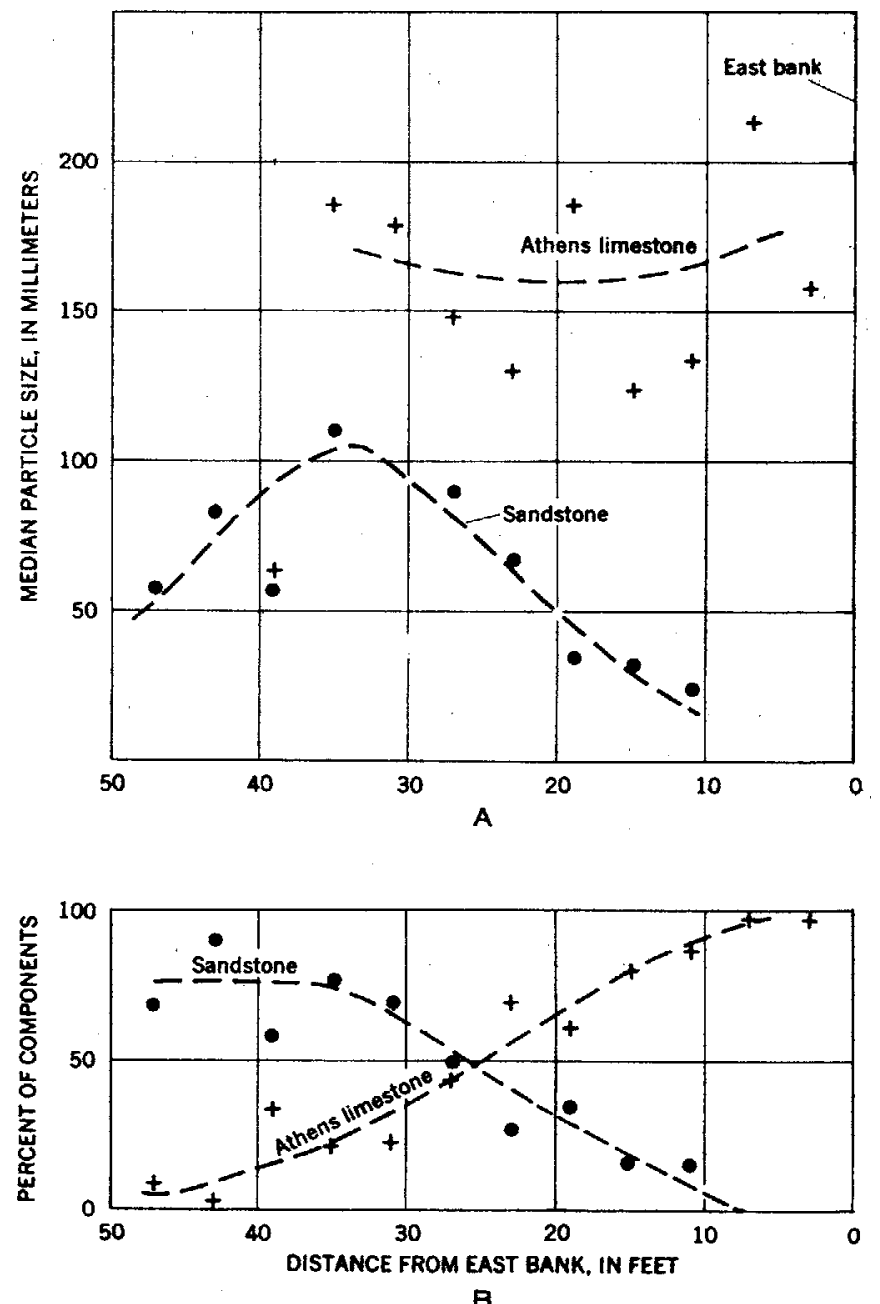

Frours 40,-Size and lithologio oomposition of bed material at locality 592 in Middle River. A, Median size of sandstone snd Athens limestone in samples at various points in the channal along a line perpendicular to the course of the stream; from the east bank. $B$, Percent of sandstone and Athens limestone in samples at various points in the channel.

are shown in figure 40. The source of the limestone is the steep slope on the east bank of the stream, and at ledges of limestone on the bottom. The sandstone is transported in the channel from upstream. Note that the Athens limestone is concentrated on the side of the stream nearest its source. The sandstone dominates the west side of the stream. As might be expected, the coarse sandstone boulders are concentrated toward the west bank, where the percentage of boulders of Athens limestone is low and where, therefore, there is less friction in the bed because of the drag of large boulders.

The distribution of the lithologic components at this locality and at locality 590 are convincing confirmation of the evidence that the coarse component is ordinarily not a part of the moving load, for the large limestone blocks are arranged next to or just downstream from their source, the remainder of the channel being occupied by the moving load.
Summary of conditions in Franks Mill reach.-The data obtained in the Middle River near Franks Mill clearly indicate that erosion along the channel and the relative resistance of the various components of the bed material are among the most important of the factors that determine size. The sandstone is the most resistant material in the reach. It persists as a large proportion of the bed material for many miles and very slowly diminishes in size because of wear or breakage. Chert is another resistant component, but, because of inherent properties such as occurrence in small masses and the presence of many small fractures, it forms the finer fractions of the load. The Lenoir and Beekmantown formations contribute materials that are somewhat less resistant and that diminish in amount rapidly with distance from the source. The softer Athens limestone is abundant in the stream only at or immediately below its source.

The data also suggest that the softest rocks may break off the bedrock in the largest fragments, though proximity to the source area is probably a much more important determinant of size. There is a very close relation between the percentage of limestone in the bed material and the incidence of cliffy slopes from which material can get into the stream by the undercutting of banks or mass movement of slope debris. Some material probably gets into the stream by plucking from the bed at riffles, as suggested at locality 575. In the Franks Mill reach the limestone component is 1.5 to 2 times as coarse as the sandstone component, and 10 to 20 times as coarse as the chert component. The median size of the whole bed load at a locality is therefore directly related to the abundance of limestone. This deduction is verified by figure 40 , a

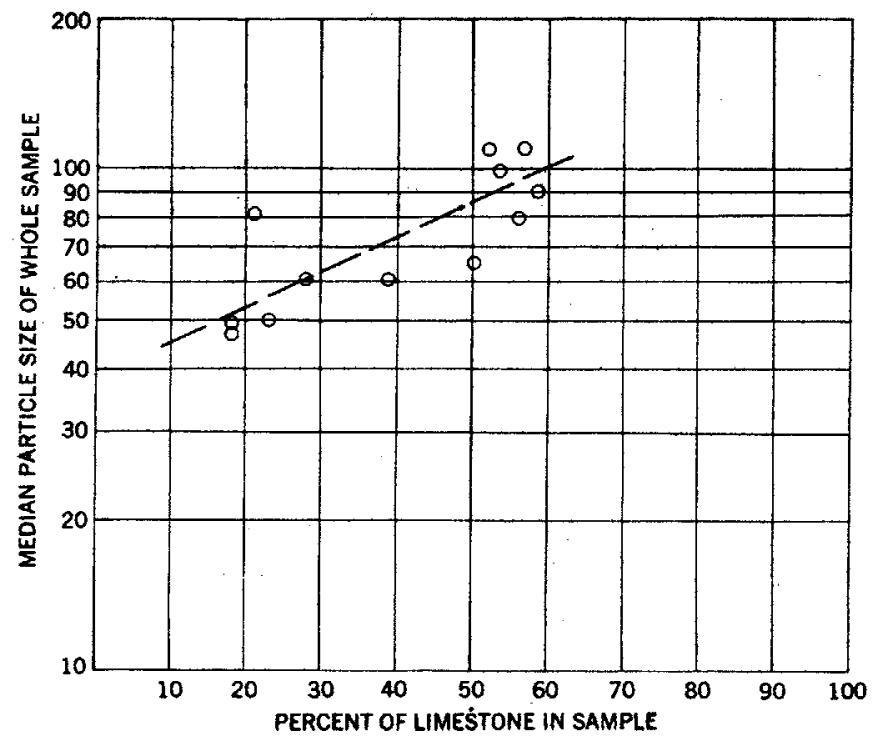

Froore 41.-Semi-logarithmic scatter diagram showing the relation between the median size of the entire sample of the bed material at the sampling localities and the percent of limestone in the sample. 


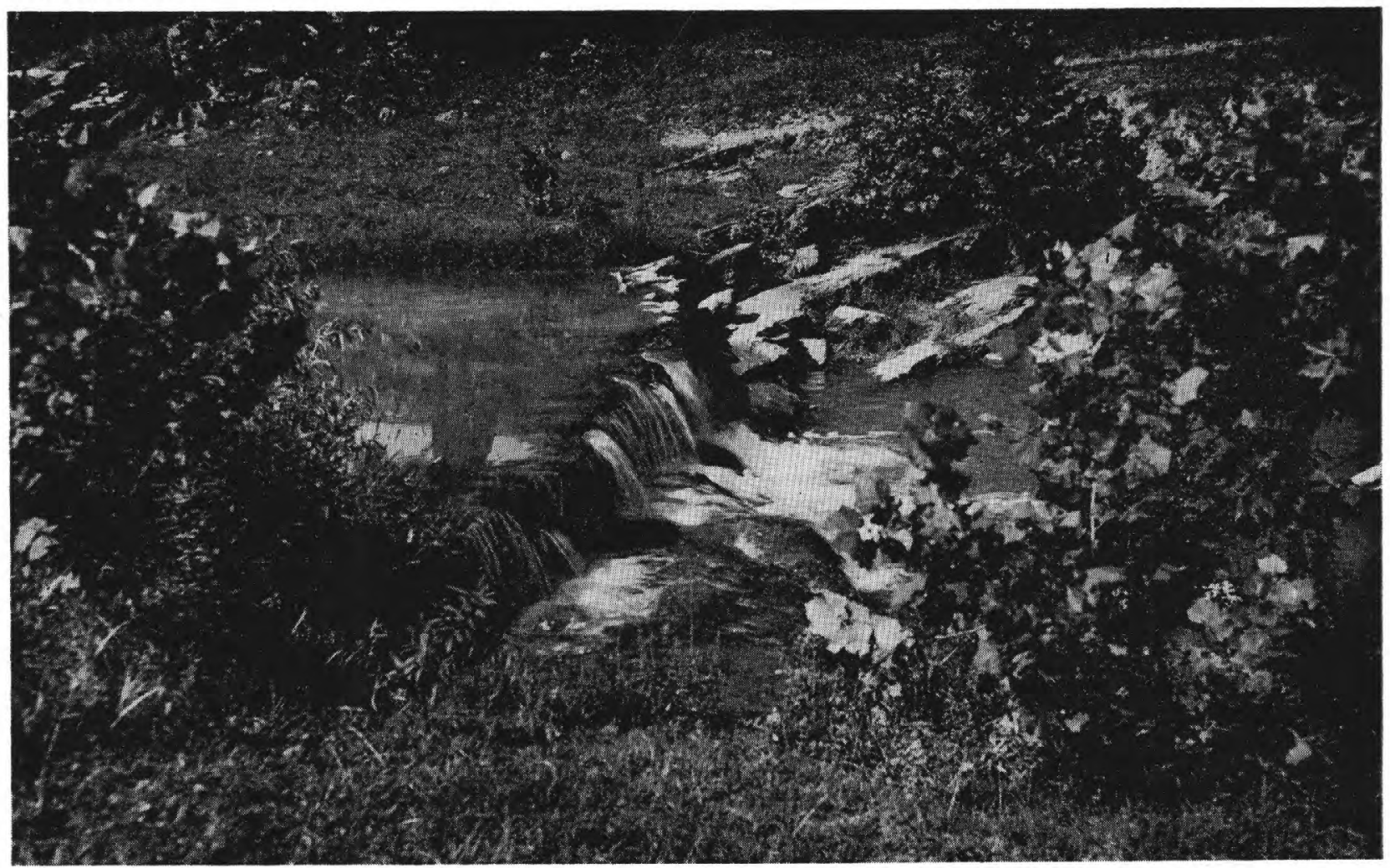

A VIEW OF FALLS IN EIDSON CREEK, VA., AT HARD BED IN CONOCOCHEAGUE LIMESTONE. River length, 8.5 miles; locality 634.

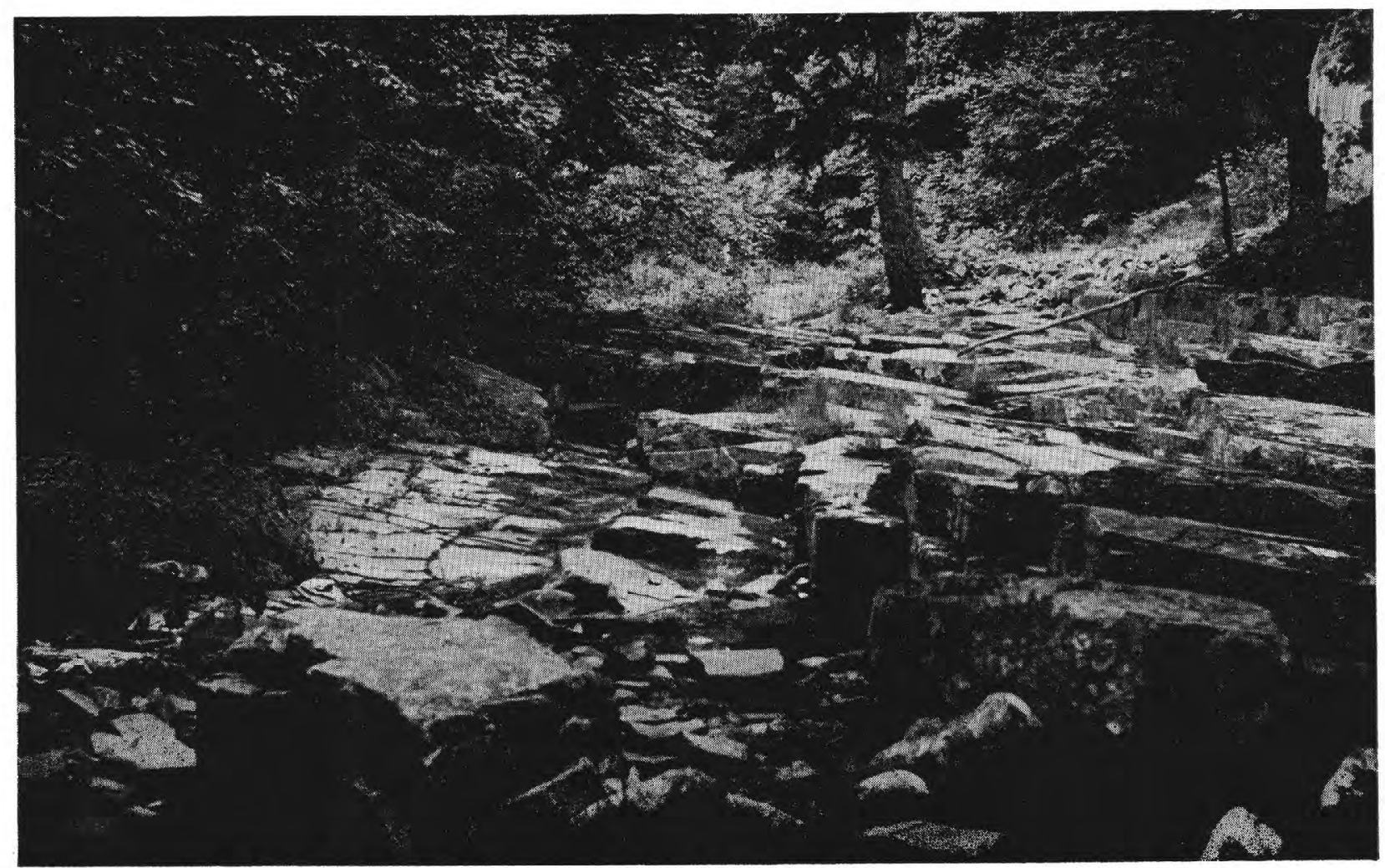

B. VIEW OF LARGE OUTCROP OF SANDSTONE IN THE BED OF EAST DRY BRANCH, VA. River length, 1.3 miles. 


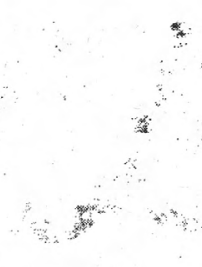

\%.

皮

s.

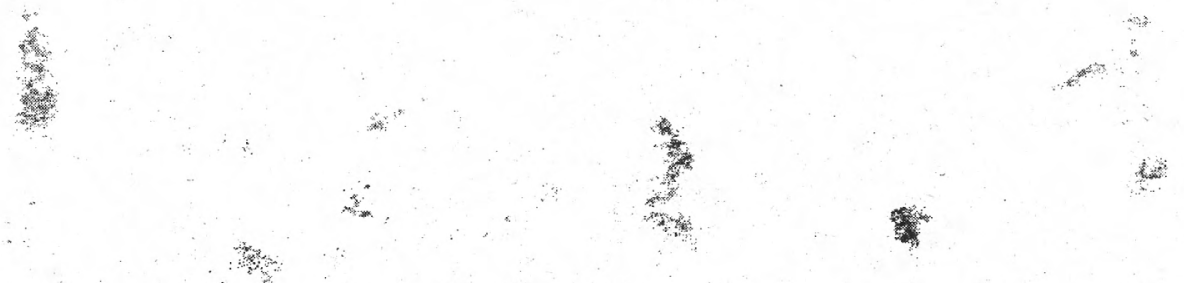

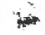

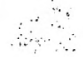

th

s: : : $\ldots$ 
graph of the relation between the median size of the whole sample and the percent of limestone in the sample.

If the median size of the whole sample is related to the percentage of limestone in the sample, and this in turn is related closely to places where bedrock is exposed, or where banks are steep, then the size of the bed material must be partly a function of the nature of the valley enclosing the channel. A steep-walled rocky valley will supply an abundance of coarse material to the bed, making the total bed load very coarse. A broad alluviated valley floor, in which the bedrock walls are far from the stream, will supply coarse material only at widely spaced intervals where the stream cuts bedrock.

\section{EIDSON CREBK}

Eidson Creek, a tributary of the Middle River, flows entirely within the limestone region. Six grid analyses were made in this stream within a reach 8,000 feet long just above its juncture with the Middle River. They are of interest because they show the association of coarse bed material with steep valley walls and a narrow flood plain. The reach is shown in figure 42, a geologic sketch map made from aerial photographs.

At the south end of the map area, the creek flows northward in a broad flood plain between fairly high banks.
At locality 639 , the bed material is mostly chert and has a median size of only about 16 millimeters. From 639 to 638 the creek continues in a broad flood plain, exposing no bedrock. At 638 the size of the bed material is about the same as at 639 . Below 638 the flood plain narrows; the banks become lower, and the river flows over a series of riffles in which bedrock is exposed. Here the bed contains blocks of limestone of the Conococheague and at locality 637 the median size of bed material has increased to 42 millimeters. Just below locality 637 the river crosses a hard ledge of siliceous oolite in the Conococheague. The ledge forms a low falls, shown in plate 10A. Below the falls at locality 634 the bed material is over 60 percent oolite and the median size is $\mathbf{6 6}$ millimeters. These oolite boulders apparently are derived entirely from the low falls, as the slopes on either side are gentle and there is no evidence of mass movement of boulders into the stream. North of locality 634, however, where the flood plain is constricted, the west bank forms high, steep slopes from which limestone slides into the stream. Below the constricted area the size of the bed material diminishes until at 635 it is only 38 millimeters. The bed material here is more than 50 percent calcareous sandstone of the Conococheague limestone. At locality 636 the bed load is again dominantly chert and the size is only about 10 millimeters.
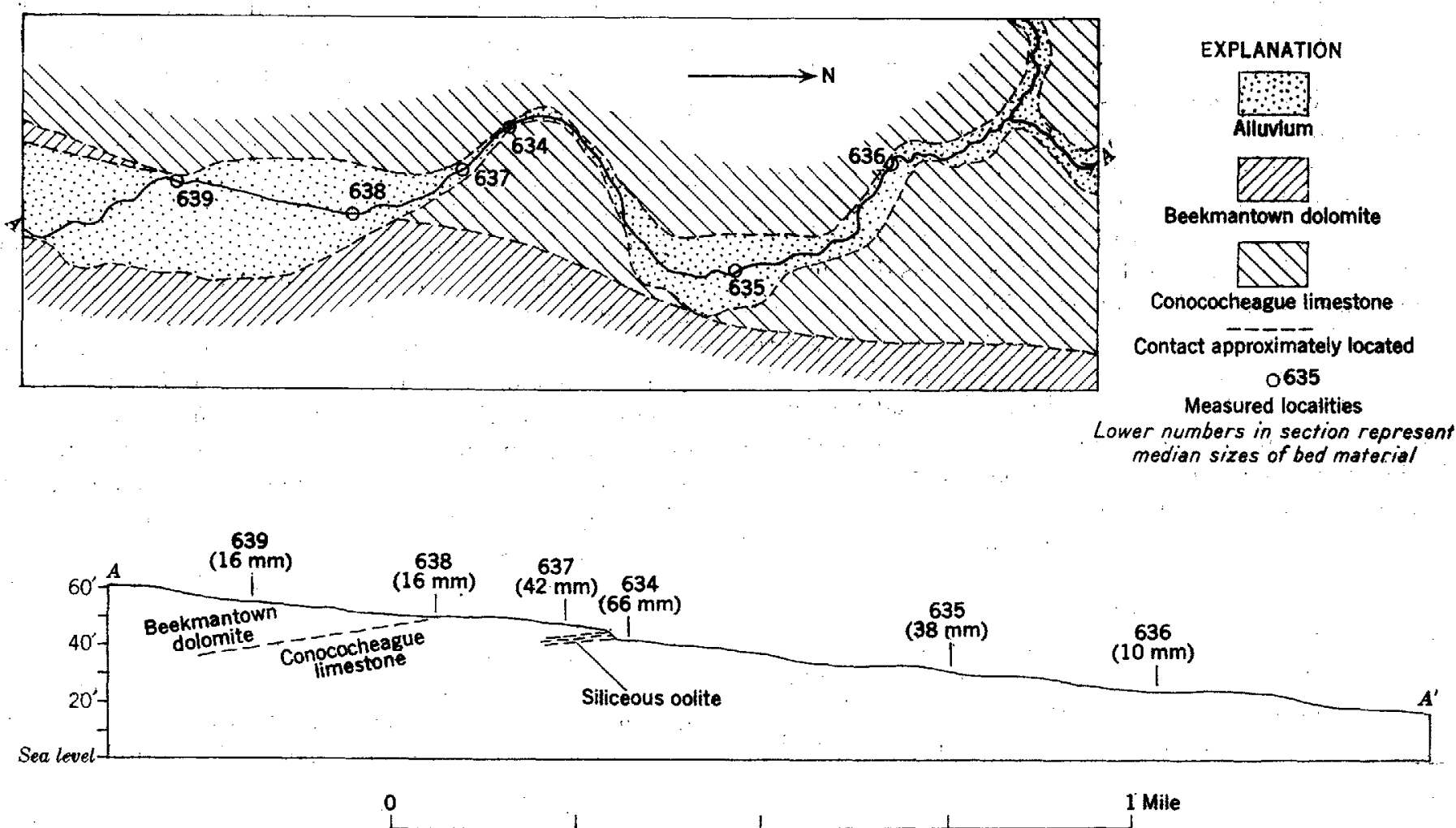

Froune 42.-Sketch map of the lower valley of Eidson Creek in the limestone region, and longitudinal profile of the creek, showing geological features. Figures in parentheses represent median sizes of bed material at the localities measured. Map sketched from aerial photographs. Profile measured in the field with plane table and telescopic alidade. 


\section{EAST DRY BRANCH}

Fast Dry Branch is another tributary of the Middle River, worth description because it is an example of a stream that is supplied with coarse bed material not only by plucking from its bed but also by mass wasting from the steep valley walls. This stream originates in a shallow syncline in the Chemung formation of Devonian age (Butts, 1940), composed of hard sandstone interbedded with shale. The headwaters of the stream are steep wooded ravines of Crawford Mountain, a ridge 3,700 feet in altitude. The valley walls are $\mathrm{V}$-shaped and rocky. The stream at a length of two miles has an average channel slope of about 200 feet per mile. The bed is littered with sandstone boulders and blocks whose average median size is from 100 to 150 millimeters. Many boulders are over 0.5 meter in diameter. In places the channel is floored by bedrock where an especially hard ledge crops out, as shown in plate $10 B$. The channel itself is 10 to 20 feet wide. It is generally flanked by a narrow flood plain composed of sand, gravel, and boulders from 10 to 50 feet wide and 3 to 5 feet high. The mountain slopes on either side are steep, their declivity is estimated to range in gradient from 30 to over 100 percent. In some places narrow terrace remnants up to 25 feet above stream grade break the steep slopes above the stream.

Mass movement on valley walls.-The valley slopes are for the most part littered by coarse angular boulders and rubble with a sandy and silty matrix. There is abundant evidence that the cover of rubble is unstable and moves downhill differentially by sliding at frequent intervals. Many trees on the slope are tilted erratically. Some are curved at the base in such a way that the trunks grow out of the ground normal to the slope, and a few feet above the ground curve upward to the vertical. This is evidence that during the early youth of the tree it was displaced by a mass movement of the rubble in which it had taken root, but that it has not been disturbed by tilting since youth. On the other hand, some trees are tilted with their trunks straight from the base outward, indicating that the movement which displaced them occurred more recently. Probably mass movements occur on such slopes during wet cycles or in exceptionally heavy storms, when the added weight and lubrication of the soil provided by excess water causes the soil in some places to become unstable and slide downward toward the stream. During very unusual periods of heavy rains large areas of rubble may be dislodged, forming talus on slopes or in ravines, in places forming terraces along the stream, or in places completely removing trees as well as rubble. Such a

The geologic work of the great flood of 1949 in the headwaters of the North River is described in an unpublished manuscript by $\mathbf{E}$. W. Read, Report on erosional manuseript report based on field surveys during summer of 1951 for the Forest Service, U. S. Department of Agriculture. The flood is also described in a manuscript now in preparation by J. T. Hack and J. C. Goodlett on the subject of regetation and its relation to erosion processes in mountain valleys of the Central Appalachians. period of heavy rain occurred in the North River basin in June 1949. Many small areas of forest were destroyed, leaving strips of barren slopes on the mountain side. ${ }^{3}$

Probably the rubble-covered slopes of these mountain valleys are in a state of dynamic equilibrium with the stream channel below. Erosion and downcutting by the stream is so rapid in relation to the lowering of the divide above that the soil mantle adjacent to the stream is not able to remain in stable position on the steep slopes. It slides downslope during very heavy rains, contributing material to the stream, which carries it away. Presumably the slides themselves are effective in eroding the slopes, through abrasion and plucking of rock fragments that have been loosened by chemical weathering along joints and by the roots of trees. Movement of the mantle takes place differentially, at intervals during years when moisture conditions are suitable. Such movement is most active at places where the stream is undercutting and is least active on slopes adjacent to a wide section of the flood plain or a terrace remnant, where the slope is protected from stream erosion by an accumulation of alluvial detritus.

Mass movement in headwater ravines. - Further evidence of mass movement is seen in nearly all the amphitheatrelike headwater ravines of the sandstone areas. Most of the larger mountain streams head at the base of spoonshaped hollows that lie between the ridges and spurs. A traverse with tape and hand level was made down the slope of Crawford Mountain, near the head of East Dry Branch, into one of these hollows and thence down the channel of the stream below. The crest of the drainage divide on the ridge top is sharp. At only 10 feet from the crest the gradient is 18 percent. It steepens rapidly, until at 250 feet (horizontal distance) the gradient exceeds 50 percent. The ground here is covered with poorly sorted sand, silt, pebbles of sandstone and shale, and boulders. Some outcrops of sandstone occur on the slope. A maximum gradient of 52 percent is reached at 544 feet from the crest of the ridge at an altitude 245 feet below the crest. At this point is an accumulation of coarse rubble, which has been washed clean of fine-grained material, but which appears stable by reason of the trees growing through it. It is composed mostly of sandstone slabs that have a median size of 120 millimeters and a sorting eoefficient of 2.3 (determined by a grid sampling). At this point the rubble accumulation is about 60 feet wide. At 605 feet the accumulation narrows to 15 feet and the gradient flattens to 44 percent. At 705 feet the valley narrows and becomes a steep-walled ravine entirely floored with sandstone slabs. A definite ephemeral stream channel begins at about 760 feet. It has banks 1 to $11 / 2$ feet high and a width of about 4 feet and is floored with sandstone slabs or rubble. At 1,300 feet, where the ravine 
is cut through shale in the Chemung formation (Butts, 1940), the width is 6 feet and the gradient is reduced to 25 percent (about 1,300 feet per mile). Median size of the bed material in the shale part of the channel is 90 millimeters. The drainage area at a distance of 1,300 feet from the crest of the ridge is 0.03 square miles.

This ravine, heading in an amphitheatre, is thought to be fairly typical of the source of many mountain streams in the sandstone area. Probably the fanlike accumulation of rubble just above the stream channel is formed by falling or by mass movement of debris because of frost. It is sorted and the fines removed during high-intensity rainfalls. As in the case of slopes bordering East Dry Branch, downcutting by the stream itself is so rapid in relation to the lowering of the ridge crest by mechanical and chemical weathering that the slope between the upper reach of the stream channel and the crest is too steep for the rubble and soil resting on it to be stable during periods of excessive rainfall. Mass movements occur at irregular but frequent intervals. The mass movements maintain a sharp ridge crest and supply material to the talus fan and stream below, which even at that short distance from its head has enough energy to carry away the material supplied to it.

Evidence of plucking.- The channel of East Dry Branch shows evidence that rock is supplied to the stream by plucking from the bed. Plucking has been discussed by G. H. Matthes (1947, p. 262) and by F. E. Matthes (op. cit., p. 262-266), who show that this process is important in removing material in large blocks. Upward forces produced by vortices in the flowing water may dislodge and lift fragments loosened along joint planes by the continuing hammerlike blows of other boulders transported from upstream. . Bedrock surfaces like those shown in plate $10 B$ are generally fresh, with sharp edges which indicate that abrasion is relatively unimportant. Fresh fractures on the edges of most large boulders attest to impact of bed material.

Concentration of large boulders near the source:-Evidence was obtained in East Dry Branch that selective transportation operates in determining the size of the bed load, just as it does in the Middle River near Franks Mill. In Dry Branch, sources of coarse bed material are so close together, because of the steep channel slopes and cliffy valley walls, that the entire channel is composed partly of a concentrate of large, angular blocks near their source and partly of smaller, more rounded material moved from upstream.

The stream crosses a shallow syncline in the Chemung: formation (Butts, 1940), in which two beds of reddish sandstone are exposed in the stream channel, as shown in figure 43. The other sandstones in the syncline are gray, or olive gray, readily distinguished from the red sandstone beds. Other reddish sandstone beds occur in the syncline,
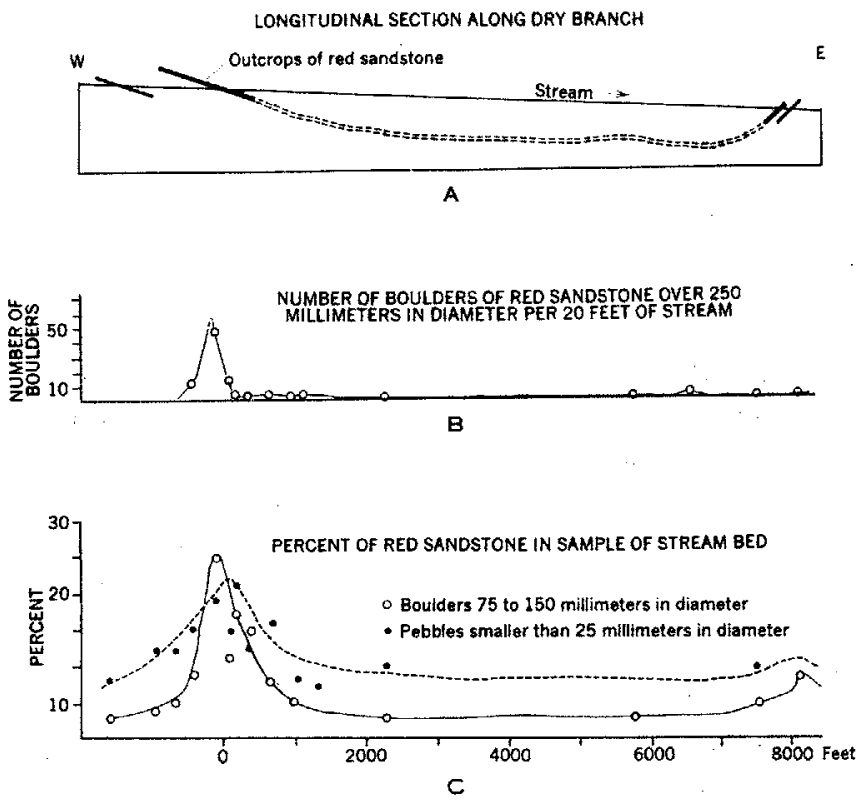

Froure 43.-Graphs showing longitudinal profile of East Dry Braneh, Va., in the Devonian sandstone area (upper graph), and relation of reddish sandstone pebbles and boulders to reddish sandstone outcrops.

but they are not cut by the stream channel and are 500 to 1,000 feet higher in the stratigraphic sequence.

Pebble counts were made of the material in the stream bed at 15 localities in the syncline below the first outcrop of reddish sandstone. These were not grid samples like the ones discussed elsewhere in this report. At each locality the total number of boulders of reddish sandstone larger in intermediate diameter than a geologic hammer handle (about 250 millimeters) were counted, within a reach of stream bed 20 feet long. Between 100 and 200 cobbles of sandstone within a size class of 75 to 150 millimeters were counted, and the percentage of reddish sandstone was tallied. Similarly, over 100 pebbles of sandstone smaller than 25 millimeters were counted at each locality, and the percentage of reddish sandstone was tallied. The results are shown graphically in figure 43 . They show that the large boulders are almost entirely concentrated in a short reach immediately on and below the outcrop of reddish sandstone. In addition, boulders upstream from the outcrop have moved into the stream, presumably by mass movement from outcrops on the slope above, or have been dislodged from a roadway upslope. At the outcrop itself the entire load of large boulders is reddish sandstone. The number in the stream drops off rapidly downstream; at a distance of only 200 feet from the outcrop, only 1 or 2 remain.

The cobbles between $\mathbf{7 5}$ and $\mathbf{1 5 0}$ millimeters in diameter also are abundant at the outcrop, but their decrease in frequency downstream is less rapid than that of the larger 
TABLE 5.-Grid analyses of material on a talus slope on the east side of the Calfpasture River valley, locality 695

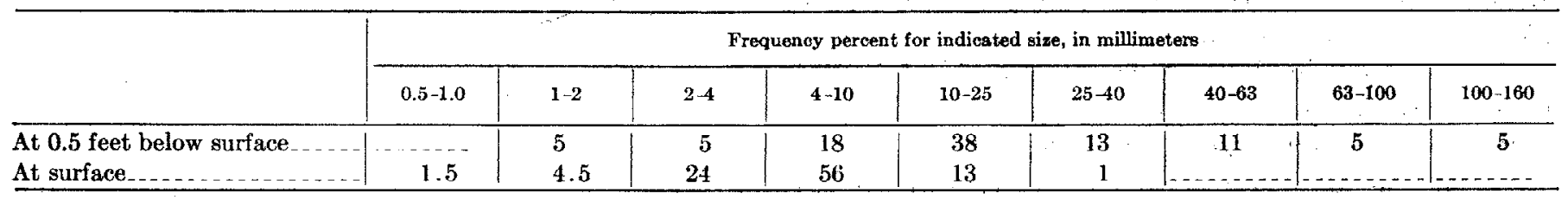

blocks. At 2,300 feet they make up less than 4 percent of the bed material, but the percentage does not diminish further. Pebbles less than 25 millimeters in diameter show a less sharp peak at the outcrop and maintain a frequency of around 12 percent all along the reach. Presumably many of the finer pebbles may originate in the red beds high on the mountain slopes and enter the stream bed in small tributaries at various places.

The reddish sandstone in Dry Branch appears to furnish good evidence of selective transportation. For the most part the large boulders in the stream remain in place. They are moved only as they are broken up by the impact of other boulders into transportable sizes. During transportation, wear or abrasion probably becomes a more important factor.

After leaving the sandstone region, Dry Branch crosses the Romney shale of Devonian age (Butts; 1940) and eventually enters the limestone region. In this part of its course the median size diminishes from more than 100-150 millimeters to between 60 and 100 millimeters. Probably Dry Branch has bed material as coarse as 150 millimeters in its upper reach because it is bordered by steep slopes that contribute large quantities of coarse material to its bed. This material is moved only as it is reduced to smaller sizes.

\section{NORTH RIVER}

'The North River, below the area of Devonian rocks, is an example of a stream in an alluvial terrace area, where the size of the bed material diminishes downstream. The river enters the limestone region in a broad flood plain (pl. 9), which it maintains almost to its junction with the Middle River. The bed material is entirely sandstone for a distance of at least 10 miles below the last sandstone outcrop. Twenty miles below the last sandstone outcrop, however, the bed material is only $\mathbf{5 0}$ percent sandstone, the remainder chert and limestone. The size of the sandstone particles decreases at a rate similar to that in the Middle River, from 110 millimeters in the sandstone area to 42 millimeters at a point 10 miles below.

Evidently the volume of sandstone debris transported from the mountains in the source area of the stream is very large; the stream is unable to carry all of it through the limestone region but has spread the sandstone gravel over a wide plain as it migrated laterally. It occasionally undercuts a limestone bank or encounters a ledge in its bed; but the limestone dislodged in these places and incorporated in the bedload is so small in amount, as compared with that of sandstone coming from the upper part of the basin, and is relatively so fragile that it does not make up even one percent of the total load.

Downstream, as the drainage area increases and with it the discharge; the amount of sandstone transported is smaller relative to the discharge, and limestone appears as a significant component of the bed material.

\section{CALFPASTURE VALLEY}

The Calfpasture River, although flowing on shale, has bed material composed entirely of sandstone. The median size of the material does not diminish downstream but remains close to 60 millimeters. Recalling the argument of page 73, it is because of the constancy in size of the bed material that the Calfpasture River has a profile whose curvature can be expressed as a logarithmic curve. It is therefore of interest to discuss the geologic conditions that control the grain size." The bed material of this river is derived entirely from outcrops not traversed by the principal stream except in its headwaters. This is similar to the North River, except that after leaving the sandstone region the North River traverses limestone and shale. As the North River flows toward its junction with the South Fork of the Shenandoah River, it is continuously moving farther from a source of sandstone. The proportion of the area of sandstone to the area of limestone in the North River basin diminishes as the total size of the basin increases. The size of sandstone transported, therefore, diminishes in proportion to the rate of wear and breakage. In the Calfpasture River, however, the valley, in shale, is flanked by mountains of sandstone, and all the major tributaries head in sandstone areas in steep mountainous terrain. As the total drainage area of the basin increases with length, the area of sandstone in the basin increases. The sandstone gravel in the river bed has therefore been transported various distances, yet has diminished little in size.

The scarcity of local bedrock, shale, in the bed material of the Calfpasture River is of interest. The shale in the lower course is mapped as Brallier and Romney shales (Butts, 1940). These formations are highly fissile and fragile, containing hard lenses of sandstone only in a few 
TABLE 6. - Median size and amount of lithologic components of bed material at localities on Gillis Falls, Md.

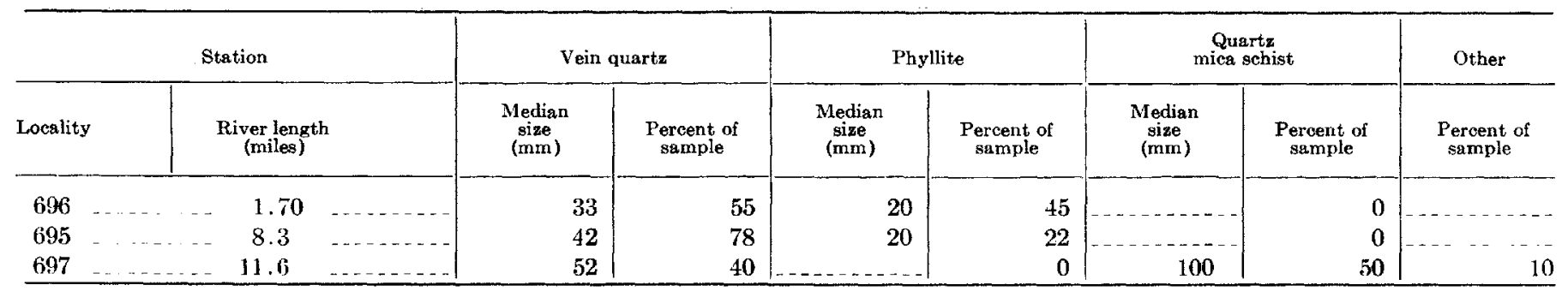

places. It is believed that they break up on exposure very rapidly into material too fine to concentrate in the stream channels. Table 5 shows the results of two grid analyses on a talus slope along a tributary of the Calfpasture River in Brallier shale. The material in the slide at a depth of 6 inches below the surface has a median particle size of 16 millimeters. The surface material, affected by more weathering, is still smaller, with a median size of only 4 millimeters. The slope of the slide is $37^{\circ}$, probably close to the angle of repose of the material. The break-up of the shale into very fine sizes, by weathering and the feeble forces associated with occasional movements of the slide, is evidence of the frailty of the material and its tendency to reduce quickly to small sizes.

Under some conditions rocks apparently break up immediately into fine sizes. It was observed in the Middle River, however, that material as fragile as calcareous tufa could be deposited in the stream as large blocks. Presumably a stream bordered by steep walls of shale might have coarse, unbroken material in its bed. Possibly the rate of erosion by mechanical processes in relation to the internal strength of the material being eroded is the important factor, and a very soft material can be expected to yield large fragments only when excavation is rapid.

\section{GILLIS FALLS}

A total of 10 grid samples were obtained in the creek known as Gillis Falls and in the South Branch of the Patapsco River below it (fig. 13). In three of them the lithologic components were identified and counted, as shown in table 6 . In the area of Wissahickon schist (Jonas, 1928) the only prominent components are phyllite and vein quartz. The phyllite generally breaks into small fragments, probably because of numerous planes of weakness, and decreases in relative amount as the discharge of the stream increases because of increased drainage area and the more resistant vein quartz becomes more abundant. In the area of Peters Creek schist (Jonas, 1928) at locality 697, phyllite is absent from the bed load and the local rock makes up half the sample. The short distance of travel of the phyllite shown by these analyses suggests that in this region as in the Franks Mill reach of the Middle
River, the more fragile components of the bed materia do not travel far as pebbles or boulders.

\section{EPHEMERAL STREAMS IN AREAS OF RESIDUUM}

A number of observations were made in small ephemeral streams in the limestone region of the Shenandoah Valley and in the headwater areas of the Piedmont. In these areas the stream channels carry water only after heavy rains, and the slopes and stream channels are mantled with fine-grained residuum and alluvium. Farther downstream the streams become perennial and the size of the bed material inereases to coarse gravel and boulders. Slopes are fairly gentle in the headwater areas, but as the streams become longer or approach the Middle River, the slopes become gentler at a rate much less than those of other classes of streams. The larger streams of the limestone area, therefore, have slopes that are fairly steep for a given length. The smaller streams have slopes that are gentle for a given length.

In the headwater areas hilltops and slopes are blanketed with a thick residual soil mantle, especially where the underlying rocks contain large quantities of siliceous materials. The soil is mostly silt or fine sand. Numerous fragments of chert occur in most of the limestone soils and are concentrated at the surface, where they form a protective blanket over the silt and sand beneath. Gullies and channols a e few and far between on the hills, even where the slc $\mathrm{p}$ ss are steep. It appears, however, that silt and sand are transported even across the cover of sod and forest litter, for the small headwater valleys are thinly floored with poorly sorted but fine-grained transported material. If transportation were not occurring the finegrained alluvium in the stream channels would be flushed out during periods of excessive discharge and would not be renewed. The apparent concentration of coarsegrained insoluble material at the top of the residiuum suggests that removal of fine-grained material from the interstream divides is a continuing process. The generalization is made that the calcareous rocks in the Middle River basin that have coarse insoluble constituents, such as chert and sandstone, are blanketed by thick residuum, whereas the rocks that have no coarse insoluble constituents, such 
TABLE 7.-Particle-size and slope data in short streams whose channels contain fine-grained soil material.

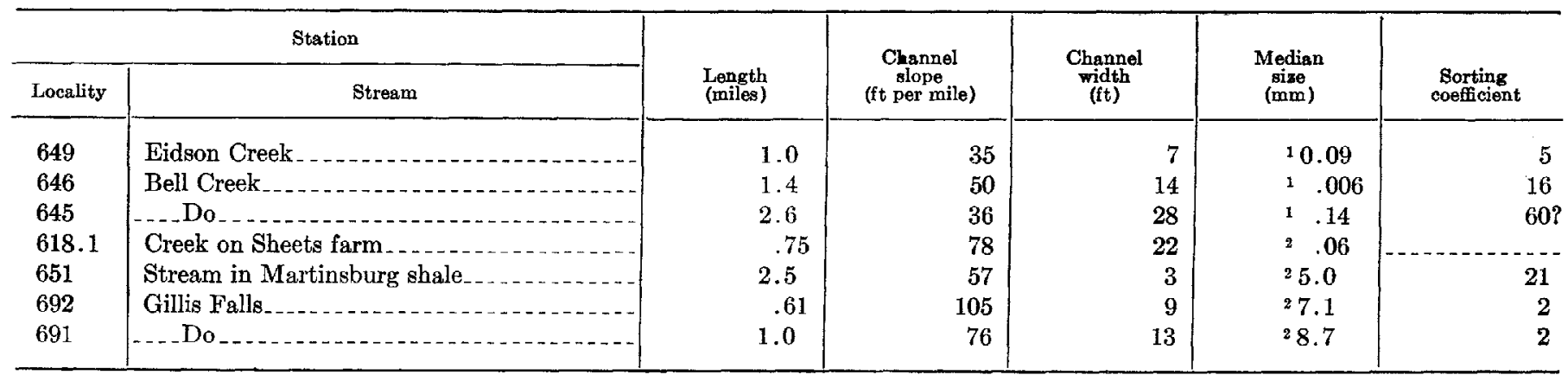

1 From complete laboratory analysis by Paul Blackmon.

2 Estimated by grid analysis in the field; error may be considerable where median size is less than $4 \mathrm{~mm}$.

as the Athens limestone or the Martinsburg shale, have very thin residuum or none at all. This is thought to be because, in an area having relief as high as the Middle River basin, the fine material can be carried away by sheet erosion, even from hilltops. Coarse chert fragments, however, accumulate on the surface and protect the fine material underneath.

In the limestone area perennial flow begins from 0.5 to 4 miles downstream from the headwaters. Beyond this point fine-grained materials are absent or rare in the channel. They do not constitute a part of the bed material, though they do make up the largest part of the flood plain. The only exception is in the few places where water plants, such as water cress, grow in profusion. These grow only in a few small perennial streams and were not observed in streams more than 15 miles long. Grassy vegetation in the ephemeral streams may play an important part in trapping fine-grained material.

Fine-grained soil material is also prominent in the alluvium of small drainage basins in the Martinsburg shale regions, where it floors small, swampy, and sod-covered channels. In these regions, soil on the hill slopes is generally only a few inches thick, and fragments of weathered shale in places project through to the surface. The thinness of the soil is not a result of grazing or farming activity alone, because similar thin soils also characterize areas of Brallier shale (Butts, 1940) in the Valley and Ridge Province, where the slopes have been tree-covered for many years. The fine alluvium in the small valleys must be derived from the transportation of weathered material during heavy rains. Since the Martinsburg shale contains no coarse fragments of silica, the weathering products are all transportable on fairly low slopes. In a region as hilly as the upper Shenandoah Valley these fine sediments probably are not held even by grassy sod.

Table 7 contains data on median particle size and sorting characteristics of the bed material of several small headwater channels. It indicates considerable variation in length of streams in which soil is an important component of the bed material.

\section{SOME FACTORS CONTROLIING VARIATION IN SIZE: CONCLUSIONS}

From the data that have been presented tentative conclusions may be drawn regarding the causes of large variations in size of bed material along the channels.

1.-Although treated only briefly in the preceding discussion, first among these is the initial size of the material. If, for example, a stream flows entirely through unconsolidated deposits, the material in the stream cannot long remain as aggregates of particles and the size composition of the bed material can only be a modification, through selective transportation, of the original material; it can not be coarser than the coarse fractions of the original material. Thus in the coastal plain of Maryland the median size of the bed material of the streams studied averages around 15 millimeters; the material appears to be mostly reworked gravel derived from the gravelly Pliocene deposits that cap the upland in this section. In the limestone region of the Shenandoah Valley the size distribution of the chert is at least partly predetermined. The chert in most of the formations examined, particularly in the Lenoir limestone, is in small masses and therefore enters the stream either in small fragments or as part of a larger limestone block. Weathering of limestone in the soil leaves chert as a concentrate of pebbles in the surface horizons to be transported directly to the streams through ravines or gullies.

2.-The joint pattern, bedding, and other structural features of the bedrock are especially important factors that determine size. Many rocks have so prominent a joint pattern that the size of the fragments resulting from the breakup of the rock is strictly limited by the spacing of the joints. This is true of the sandstones and quartzites in the Devonian and Mississippian rocks west of the Shenandoah Valley. The detritus on slopes as well as the material in the stream beds that is derived from some 
formations is consistently smaller than that from others. The coarseness of the granodiorite boulders in the Tye River is another example. This rock is very massive and weathers into large spheroidal masses with few joints intersecting them. As a consequence the fragments originally supplied to the stream can be of very large initial size.

3.-Resistance of the rock to abrasion and breakage must be an important factor controlling size in the streams, as is indicated by the influence exerted by the sandstone in the Middle River on the total size of the bed material for dozens of miles below its source. Limestone, on the other hand, is apparently broken up in a short distance of travel and only the included chert is persistent.

4.-Resistance of the rock to chemical attack is another factor of importance. In the limestone region, for example, the rate of weathering is sufficiently rapid that the ephemeral stream channels are floored by the fine-grained products of weathering, and the channel slopes are adjusted for the transportation of these sizes. Weathering may also influence the size of the bed material in large streams, for the wastage of slopes along streams by reason of soil formation, weathering, and sheet erosion will reduce the number of steep slopes and rock outcrops at which the streams can pick up coarse fragments.

5.-The relief of the region bordering the stream seems to be significant. It is intimately related to the slope of the stream itself, as the relief is largely a function of the form of the longitudinal profiles of the headwater streams. Where the slopes are steep and the valley floor narrow, opportunities are afforded for large quantities of rock to break up along joint planes and accumulate in the channel by mass movement and lateral planation.

The most significant conclusion to be drawn from the data is that it is not exclusively an inherent property of the bedrock that determines the particle size of bed material in streams; nor is it the relief or stage of development of the terrain. Size is determined by a relation among several factors, and furthermore the relation between these determining factors and the long profile is such that they are interdependent.

\section{THE longrtudinal PRofile AND THE CyCle OF EROSION}

It has been shown that several factors related to both physical and chemical properties of the bedrock are important in controlling the longitudinal profile. Of principal interest to the geomorphologist is the suggestion on page 69 , shown by the graph of figure 29 , that within areas where the bedrock geology is the same there is a consistent relation between channel slope and length; that is, in geologically similar areas stream profiles are similar. Figure 44 is a diagram of the relation between stream length and channel slope (the derivative of the longitudinal profile) for various localities in the sandstone region west of the Shenandoah Valley, and in the Martinsburg shale area. The localities shown on the diagram include only those for which most or all of the drainage basins are within areas of one kind of bedrock. Very good correlation is shown between slope and length for each of the two regions. Similar curves have been constructed for other

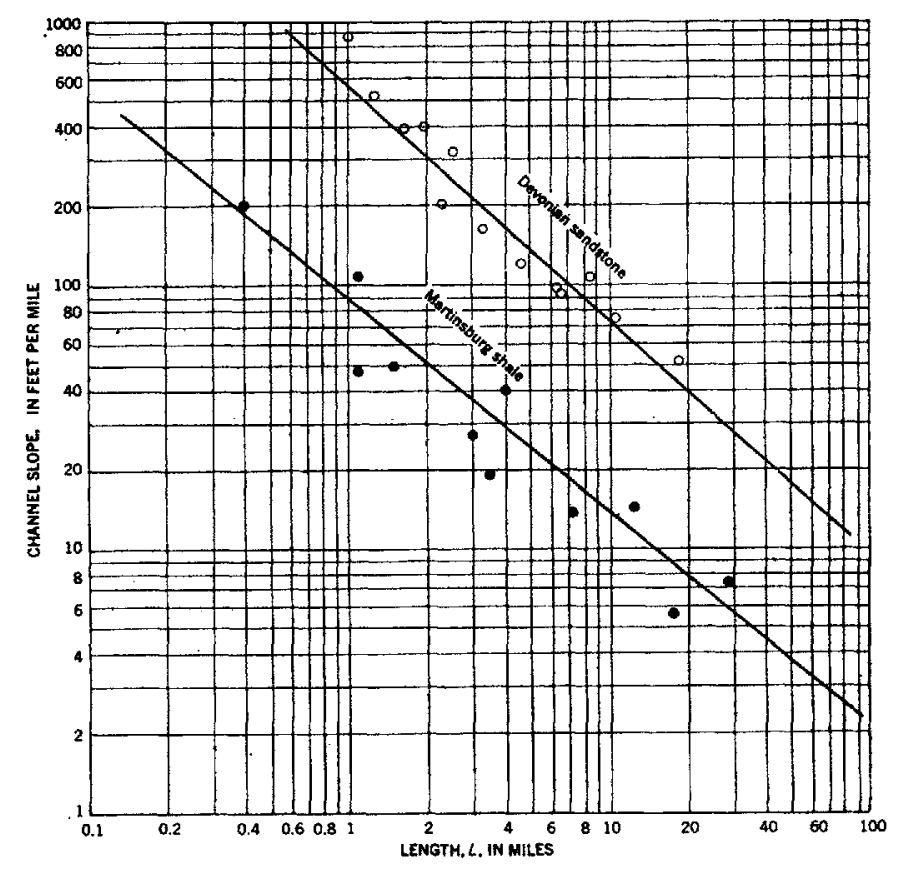

Figure 44.-Logarithmic scatter diagram showing the relation between slope and length at points in the Devonian sandstone and Martinsburg shale areas, Middle and North River basins, Va. Figures on graph represent the average values of stream slopes at a length of 1 mile.

areas. The result is summarized in figure 45 , which shows the relation between slope and length for streams in seven geologically different areas. Area 1 is in the granodiorite on the east slope of the Blue Ridge, which includes the Tye River basin. Here slopes at 1 mile are between 600 and 700 feet per mile. They flatten out gradually so that at 8 miles the slopes are only 250 feet per mile. All the streams originating within this area are small, hence data are not available to check the curve at lengths greater than 8 miles. Area 2 is in the sandstone of Devonian age and includes many localities in the basins of Buffalo Branch, Dry Branch, and the North River. Here slopes are very steep in the headwaters but diminish rapidly downstream. In area 3, slopes are less than in the Devonian sandstone area. This area includes localities in the Calfpasture valley and a few in the alluvial terrace areas of Dry Branch and the North River. In these areas the bedrock is shale or limestone, but the river channel is in alluvium composed entirely of sandstone boulders carried downstream from above. Area 4 includes localities in the limestone region, all of which are in streams whose basins are mostly within the limestone region. 
Area 5 is drawn through points in the basin of Gillis Falls, Md. Area 6 includes localities in the drainage basin of Christians Creek and includes some localities from Opequon Creek, near Winchester, Va., (not shown on the map). Area 7 is in the Coastal Plain of Maryland, in an area underlain by unconsolidated sandy sediments and some clay and diatomaceous earth, in Calvert County, Md.

The total range in values of slope is large. The values are based entirely on data obtained in small drainage basins. Large drainage basins whose lengths are over 60 miles have not been considered in the study. Examination of a few localities on the main stems of the Potomac River and the Susquehanna River, however, indicate that the same curves will probably not apply to rivers of such large size. These streams appear to have slopes that are much steeper in relation to the drainage area than the slopes of the smaller streams studied. It is not feasible, however, on the basis of the present study to make geologic comparisons between the basin of a large river such as the Potomac and a basin as small as that of East Dry Branch.

The areas chosen for analysis in figure 45 must each have streams within their boundaries that have similar longitudinal profiles, since the profile is the integral of the relation between slope and length. Using the constants obtained from figure 45, profiles typical of these regions may be constructed by integration as shown on page 70 . The calculation has been made for four of the regions, and the resulting profiles are shown in figure 46 . In the calculations made for this diagram the assumption was made, for purposes of comparison, that each stream

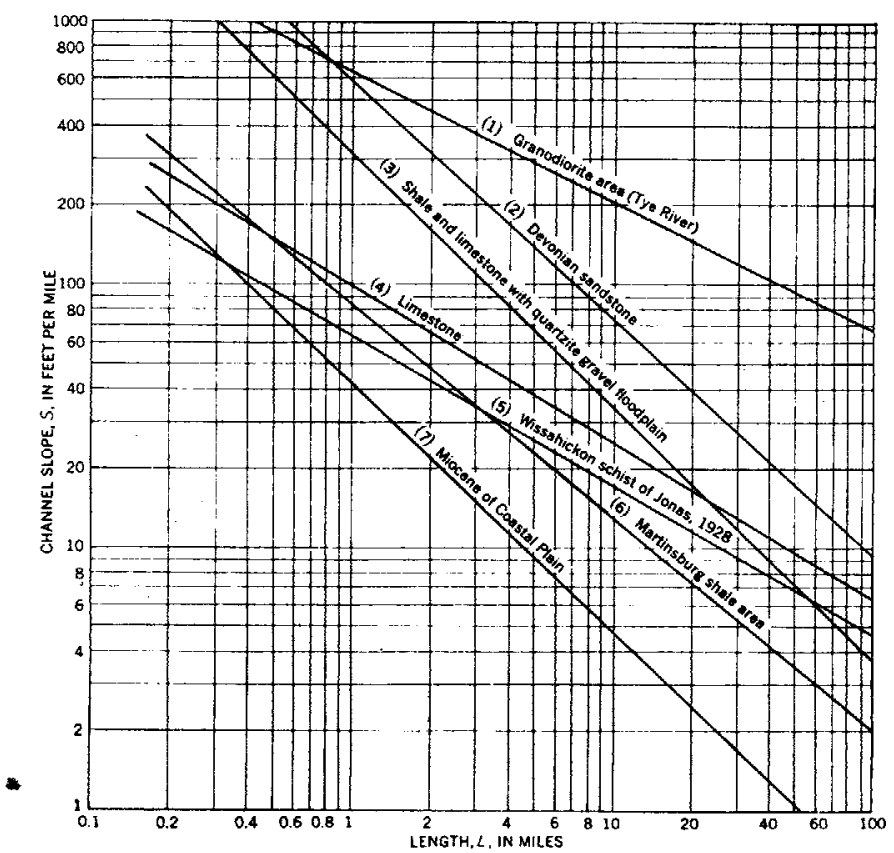

Figure 45.-Logarithmic graph showing the average relation between channel slope and stream length at localities on streams in seven geologically di feret.t areas. reached an altitude of 1,000 feet at a length of 10 miles. As the diagram shows, the differences between some of the profiles are quantitatively very large. A stream entirely in sandstone of Devonian age that has an altitude of 1,000 feet at a river length of 10 miles would be at 2,380 feet at a length of 1 mile, 3,100 feet at 0.3 mile, and over 3,760 feet at 0.1 mile, which is about the position of the inflection point of slopes in the sandstone area. On the other hand, a stream on the Coastal Plain of Maryland, in the outcrop area of the Miocene sediments would rise from 1,000 feet at a length of 10 miles from the source to only 1,100 feet at 1 mile, 1,150 feet at 0.3 miles, and 1,200 feet at 0.1 miles. Further rise is limited by the position of the inflection point with respect to the drainage divide; that is, the point at which the profile becomes convex to the sky. The location of this point in relation to the geology and the stream channel is not considered in this report but it is probably a factor of importance.

Many streams pass through areas of several kinds of bedrock, and their beds contain materials from more than one source area. The Middle River and its tributary

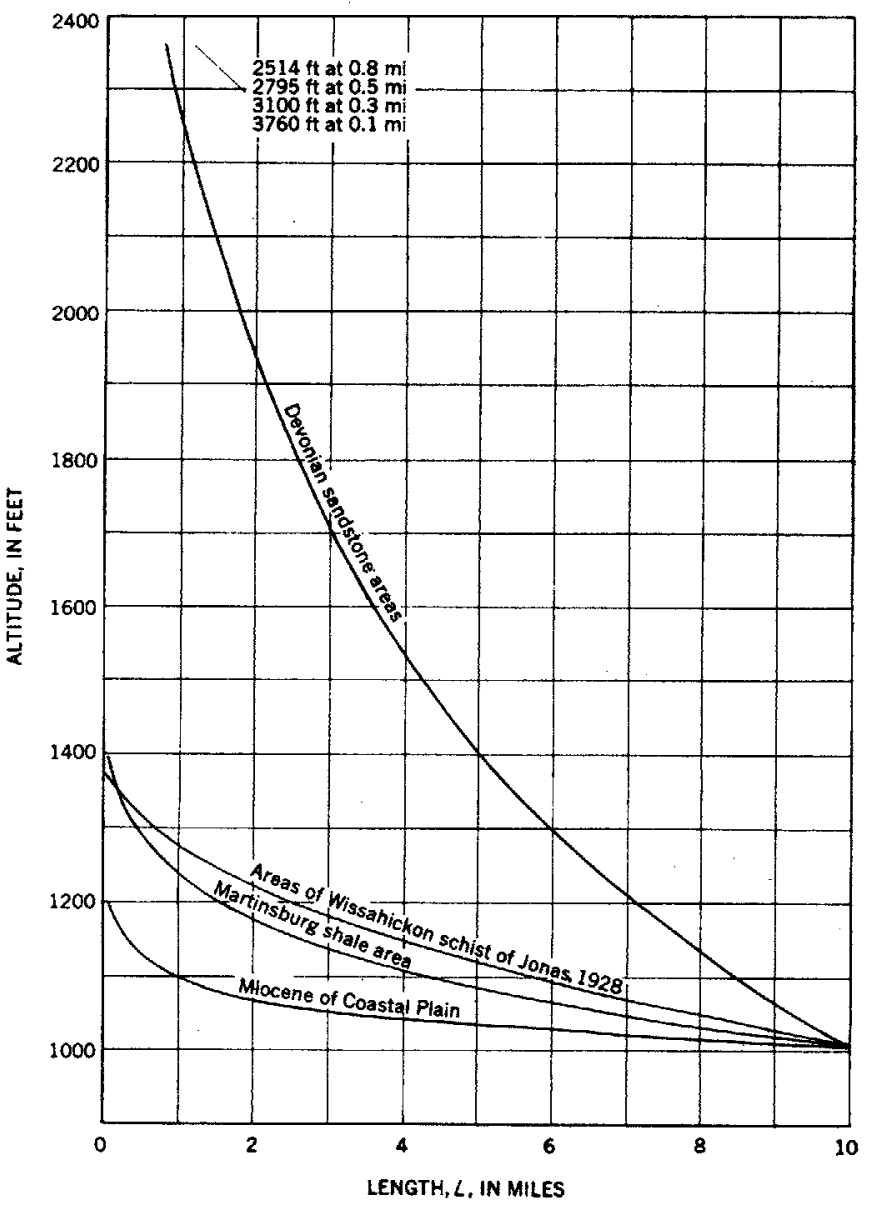

FIG RE 46.-Longitudinal profiles computed from the constants of four of the curves shown in figure 45 . It is assumed that all four profiles have a comson altitude at a length of 10 miles. 


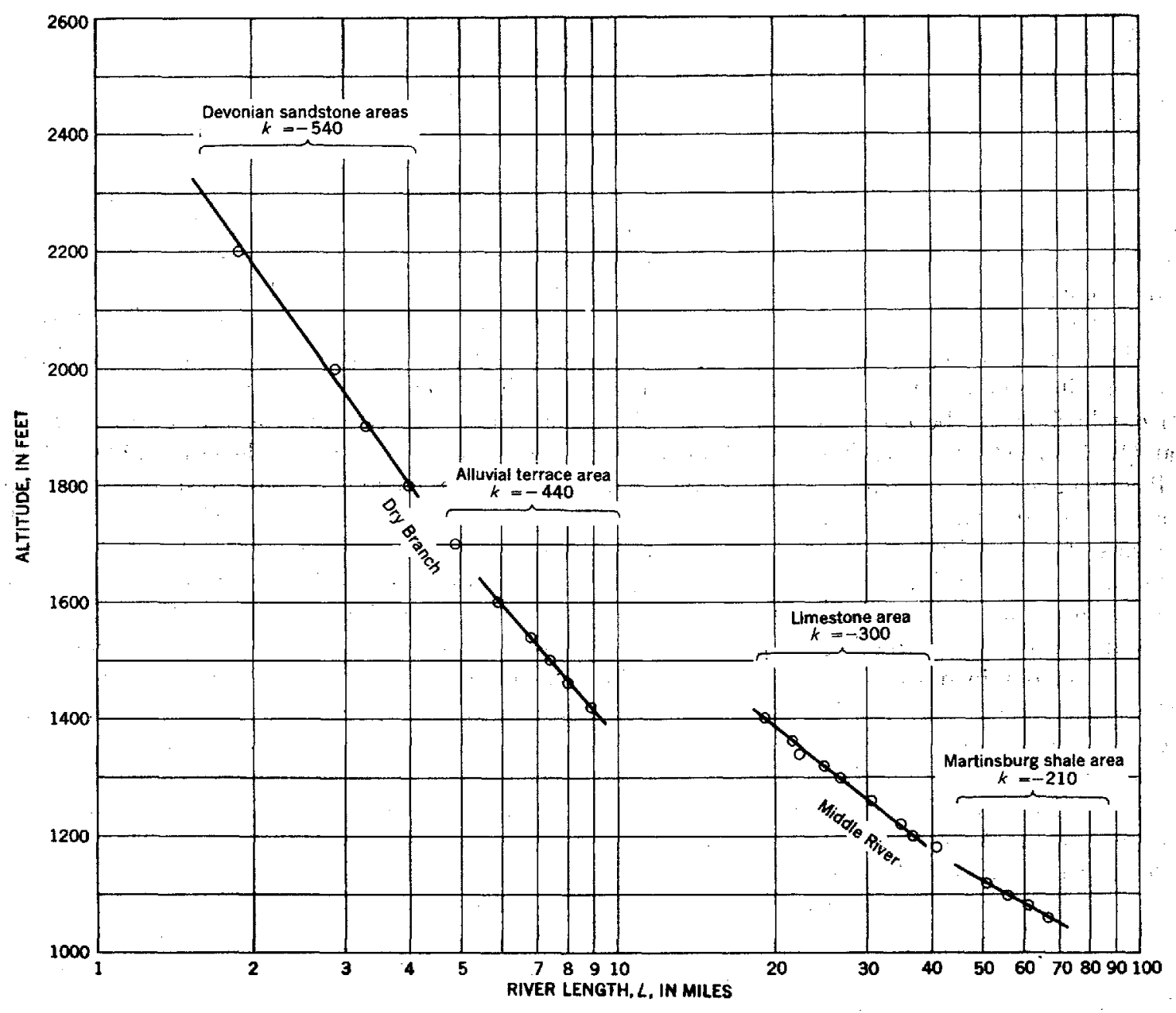

Frever 47. - Longitudinal profiles of East Dry Branch and the Middle River drawn on a semilogarithmic graph to show the relation between the geologic features and the profile.

East Dry Branch offer a good example. The profiles of these two streams are plotted on a semilogarithmic graph in figure 47. The breaks in profile occur exactly at the major geologic contacts. These breaks, which would not show up clearly in a conventional type of profile (on an arithmetic graph), show up sharply on this kind of graph. The reaches of river in which the bed material is approximately constant appear as straight lines, having a general formula of the same form as equation 10 ,

$$
B=C-k \log _{e} L
$$

where $B$ is the altitude of a point on the stream in feet, $L$ is the river length in miles and $k$ and $C$ are constants. The constant $k$ must be equivalent to the constant $25 j^{0.6}$ in equation 14 (p. 72) and is therefore proportional to a power of the size of the bed material.

It is thought that the constant $k$ in an equation like the one above may prove to be a useful index for the study of topography. Its relation to the size of bed material, as demonstrated empirically by the present analysis, suggests that it is in some way related to the competence of streams.
The constant $k$ is readily determined on topographic maps at any point on a stream without drawing the profile. It does not matter whether the profile actually follows a logarithmic curve, because it may be assumed that if it does not follow such a eurve, it is made up of small segments of a series of logarithmic curves, each of which has a different value of $k$ (as illustrated by fig. 47). It can be shown algebraically that the value of $k$ is equivalent to the difference between the altitude of two points on the profile, divided by the difference between the natural logarithms of the lengths at the same two points.

$$
\frac{H_{1}-H_{2}}{\log _{e} L_{1}-\log _{e} L_{2}}
$$

It is even more easily determined in another way. As shown on page 70 the constant $k$ of equation 16 occurs also in the equation relating slope to length,

$$
S=\frac{k}{L}
$$

and

$$
k=S L .
$$


The constant may therefore be quickly determined simply by measuring the distance from the origin of a stream to a point on the stream and then multiplying this value by the slope at that point. Calculations are most easily made in miles and feet per mile, but of course other units can be used.

The close relation between the lithology of an area and the form of the long profiles within the area suggests that a state of dynamic equilibrium exists between the amount of relief and the form of the erosion channels on the one hand, and the resistance of the bedrock to the forces tending to break it up and remove it on the other. This concept of equilibrium has been discussed in some detail by Wolman (1955) in a study of the channel of Brandywine Creek, a Piedmont stream in eastern Pennsylvania that traverses a lithologically varied region. An analysis of a region in terms of its longitudinal profiles therefore may be a valuable approach to the interpretation of a landscape. This writer has been concerned only with establishing some of the factors important in determining the profile. Data have not yet been obtained to determine the range in values of the constants for a region as large as the Potomac Basin, or the relation of the profile to the stage of geological development of various areas. Such an analysis may be attempted at another time. Nevertheless some tentative observations may be made concerning the meaning of the data just described in terms of the erosion cycle.

The relation found between topography and the size of the material on the stream beds in a region such as the Shenandoah Valley accords with some of Davis' classic observations on the development of the cycle of erosion and the flattening of divides (Davis, 1909, chapter 13). On the other hand the differential resistance to erosion and weathering of regularly arranged belts of rock may in itself account for the regularity of the topographic forms of a region, without recourse to an explanation involving multiple erosion cycles, such as has long been generally accepted for the northern Appalachian region.

In an early stage, when the total relief is great, it must be expected that interstream slopes are steep; coarse material moves down the slope by mass movement and accumulates in the stream channels. This accumulation of detritus may be coarse or fine from place to place, its size depending on the discharge of the stream channels and the slopes on which the water is carried off. As erosion proceeds the channels become more regular in longitudinal section and approach a parabolalike shape, concave to the sky; for the streams in their downstream reaches are more powerful and can carry away far larger material on low slopes than can the streams in the headwater reaches.

Various processes must act to reduce the interstream divides at the same time or they would extend upward like knife blades between the concave stream profiles on either side. Presumably they are blunted by processes of mechanical and chemical weathering that break the rock into particles fine enough to be moved by creep, sheet erosion, or in slides. In a steep mountain area, therefore, where the processes of mass movement are active, we may expect the divides to be sharp, because chemical or mechanical decay of the rock on the summit itself is slow in comparison with the retreat of the slope because of mass movement related to downcutting of the stream. The steepness of the stream channels below is of course determined at the outset by the total relief. With a very high relief the rate of sapping of the bedrock and its accumulation in the channels is high. So is the rate at which the detritus on the stream beds is broken or carried off.

As time goes on, if base level is stable and erosion continues, the channel slopes must obviously flatten. In terms of the bed material, this means that the rate of removal of bed material from the channel at any place diminishes. Concomitantly, the rate of undercutting of banks and plucking must diminish and the rate of transportation on interstream slopes by mass movements-and, therefore, the rate of mechanical weathering-must also diminish. The processes acting on the interstream divides and summits, however, presumably are not affected by the flattening of the slopes at the same rate. For example, the rate of chemical weathering of rocks such as mica schist or limestone is less affected. As erosion continues, the rate of chemical weathering becomes relatively more important, and mechanical erosion of the channels and mass movement of the coarse debris on slopes relatively less important. Eventually it may be expected that the products of chemical weathering form an appreciable part of the material that must be removed by the stream. At this point the stream valleys are like that of Gillis Falls or those of the limestone region, where there are low divides at the headwaters and gentle upstream slopes, but where the downstream reaches are more incised. In an area of a single kind of rock, therefore, the cycle at one stage involves profiles that have a high degree of curvature. As erosion continues the profiles flatten because weathering and the blunting of the divides is relatively more important than stream erosion. Such flattish profiles can be expected to be most pronounced where the rocks are most susceptible to chemical decay.

Presumably the cycle described above is completed more rapidly in an area of soft rocks than in an area of resistant rocks. Thus, under the conditions of erosion that occur in the Potomac valley, the break-up of rock in the channels in a quartzite area must be relatively slow and the rate of weathering must be slow, whereas in a limestone area we may expect these rates to be high. It follows that if two areas in this region, one of limestone, and one of sandstone or quartzite, have the same initial relief, at any later stage of development they will differ in relief. The profiles in the limestone area are reduced 
TABLe 8.-Principal measurements at selected localities

\begin{tabular}{|c|c|c|c|c|c|c|c|c|c|c|c|}
\hline Locality & River & $\begin{array}{l}\text { Length } \\
\text { (mileg) }\end{array}$ & $\begin{array}{c}\text { Area } \\
\text { (sq miles) }\end{array}$ & $\begin{array}{c}\text { Slope } 1 \\
\text { (ft per mi) }\end{array}$ & $\begin{array}{c}\text { Local } \\
\text { Slope } \\
\text { (ft per mi) }\end{array}$ & $\underset{\text { (mm) }}{\text { Median }}$ & $\underset{\text { sorting }}{\text { Trask }}$ & $\begin{array}{l}\text { Area of } \\
\text { oross seotion } \\
\text { (sq feet) }\end{array}$ & $\begin{array}{l}\text { Width } \\
\text { (feet) }\end{array}$ & $\underset{\substack{\text { Depth } \\
\text { (feet) }}}{\bullet}$ & Depth:width \\
\hline \multicolumn{12}{|c|}{ Streams in limestone and dolamite } \\
\hline 649 & Eidson Creek & 1.0 & 0.54 & 35 & 37 & $\cdots$ & 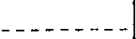 & 7.4 & 7.0 & 1.05 & 0.15 \\
\hline 648 & do & 2.25 & 2.5 & 47 & 50 & 7 & 4.5 & 29 & 18 & 1.6 & .09 \\
\hline 647 & do & 5.5 & 8.1 & 31 & 44 & 17.5 & 2.0 & 46 & 22 & 2.1 & .095 \\
\hline 639 & do & 7.8 & 13.3 & 23 & 27 & 16 & 2.2 & 71 & 23 & 3.1 & .134 \\
\hline 638 & do & 8.0 & 13.5 & 23 & 28 & 16 & 2.2 & & & $\ldots$ & $\ldots$ \\
\hline 637 & do & 8.3 & 13.6 & 27 & 43 & 42 & 2.3 & 16.2 & 19 & .8 & .045 \\
\hline 634 & do $\ldots \ldots$. & 8.5 & 13.7 & 27 & 160 & 66 & 2.1 & 19 & 17 & 1.1 & .065 \\
\hline 635 & do $\ldots \ldots$. & 9.0 & 14.3 & 27 & 53 & 38 & 1.7 & 55 & 23 & 2.4 & .105 \\
\hline 636 & do $\ldots \ldots$ & 9.2 & 14.4 & 18 & - & 10 & 2.25 & 74.5 & 30 & 2.5 & .083 \\
\hline 646 & Bell Creek $\ldots \ldots$ & 1.4 & 0.63 & 50 & 63 & $\ldots$ & $\ldots$ & 7.6 & 14 & .5 & .038 \\
\hline 645 & do do & 2.6 & 3.6 & 36 & 20 & $\ldots$ & $-\ldots$ & 40 & 28 & 1.4 & .05 \\
\hline 644 & - do do & 5.7 & 9.8 & 20 & 20 & 10 & 4.1 & 36 & 28 & 1.3 & .046 \\
\hline 630 & Folly Mills Creek & 0.95 & 0.38 & 90 & 102 & 16 & 1.9 & 12.8 & 11 & 1.2 & .109 \\
\hline 631 & do do & 3.15 & 2.84 & 95 & 53 & 68 & 2.8 & 16.3 & 12 & 1.4 & .116 \\
\hline 632 & _do d $_{1}$ & 5.4 & 7.5 & 45 & 44 & 11.2 & 2.5 & 66 & 33 & 2.0 & .060 \\
\hline 624 & Middle River & 11.0 & 42.5 & 11.5 & $\ldots$ & 22 & 2.1 & $\ldots . . .100$ & & & $\ldots$ \\
\hline 623 & - do & 16.1 & 62.9 & 13 & 44 & 142 & 2.2 & 84 & 42 & 2.0 & .047 \\
\hline 622 & {$\left[\begin{array}{cc}\text { do } \\
-1\end{array}\right.$} & 18.4 & 97.7 & 18 & 72 & 74 & 2.1 & 178 & 76 & 2.3 & .030 \\
\hline 615 & {$\left[\begin{array}{l}-1 \\
-10\end{array}\right.$} & 23.2 & 136.7 & 6.9 & 52 & 45 & 2.1 & 122 & 59 & 2.1 & .036 \\
\hline 575 & . . do . . . . & 24.3 & 147.9 & 6.9 & $-\ldots$ & 58 & 2.3 & 268 & 90 & 3.0 & .033 \\
\hline 576 & do & 24.5 & 147.8 & 6.9 & - . . - & 105 & 2.5 & 357 & 97 & 3.7 & .038 \\
\hline 589 & do do & 24.9 & 148.2 & 9 & $\ldots$ & 59 & 2.7 & 199 & 134 & 1.5 & .012 \\
\hline 588 & do & 25 & 148.5 & 6.9 & 69 & 50 & 1.8 & 219 & 160 & 1.35 & .008 \\
\hline 592 & do & 26.3 & 150.6 & 10.5 & $\ldots$ & 110 & 1.6 & 322 & 91 & 3.5 & .038 \\
\hline 591 & - & 26.6 & 151.0 & 10.5 & $\ldots$ & 81 & 1.1 & 185 & 59 & 3.1 & .052 \\
\hline 597 & $-n_{1}$ & 28.1 & 179.9 & 10.0 & $-\ldots$ & 49 & 2.6 & 496 & 103 & 4.8 & .048 \\
\hline 593 & 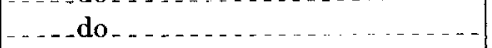 & 28.7 & 180.5 & 10.0 & & 110 & 2.0 & 304 & 83 & 3.6 & .043 \\
\hline 596 & . . do _ . . . & 29.2 & 180.9 & 10.0 & $\ldots$ & 91 & 1.4 & 224 & 78 & 2.9 & .038 \\
\hline 619 & . . do . . . & 31.2 & 184.8 & 10.0 & 65 & 65 & 1.3 & 158 & 88 & 1.8 & .020 \\
\hline 617 & . . . do _ . . & 31.7 & 184.9 & 10.0 & -10-1 & 80 & 2.25 & 247 & 84 & 2.9 & .035 \\
\hline 599 & $\ldots$. . do _ . . . & 34.4 & 192.5 & 9.5 & $\ldots \ldots$ & 64 & 1.5 & - & & $\ldots$ & $\ldots$ \\
\hline $652 \mathrm{~A}$ & - _ do do & 65.0 & 379 & 4.1 & 4.6 & 42 & 2.0 & 277 & 85 & 3.2 & .038 \\
\hline $652 \mathrm{~B}$ & North River & 39.7 & 375 & 5.7 & & 64 & 2.2 & & & & \\
\hline
\end{tabular}

See footnotes at end of table. 
ТАВLE 8.-Principal measurements at selected localities-Continued

\begin{tabular}{|c|c|c|c|c|c|c|c|c|c|c|c|}
\hline Locality & River & $\begin{array}{l}\text { Length } \\
\text { (miles) }\end{array}$ & $\begin{array}{c}\text { Area } \\
\text { (sq miles) }\end{array}$ & $\begin{array}{c}\text { Slope } 1 \\
\text { (ft per mi) }\end{array}$ & $\begin{array}{c}\text { Local } \\
\text { Slope } \\
\text { (ft per mi) }\end{array}$ & $\underset{\substack{\text { Mrain size } \\
(\mathrm{mm})}}{\operatorname{codian}}$ & $\begin{array}{l}\text { Trask } \\
\text { sorting }\end{array}$ & $\begin{array}{l}\text { Area of } \\
\text { cross section } \\
\text { (sq feet) }\end{array}$ & $\begin{array}{l}\text { Width } \\
\text { (feet) }\end{array}$ & $\underset{\text { (feet) }}{\text { Depth }}$ & Depth:width \\
\hline \multicolumn{12}{|c|}{ Streams in Marlinsbury shale } \\
\hline 651 & Tributary of Christians Creek & 2.5 & 1.1 & 57 & 11 & 5 & 21 & 1.2 & 3.0 & 0.4 & 0.13 \\
\hline 658 & Poor Farm Draft $\ldots \ldots \ldots$ & 4.1 & 3.15 & 36 & 52 & 23,6 & 2.45 & 22.5 & 27 & 0.84 & .03 \\
\hline 633 & Folly Mills Creek & 9.7 & 17.09 & 33 & 29 & 45 & 3.0 & 52.8 & 22 & 2.4 & .11 \\
\hline 650 & Christians Creek & 11.5 & 26.8 & 14 & 29 & 16 & 1.6 & 56 & 27 & 2.1 & .08 \\
\hline 657 & do & 17.6 & 56.2 & 7.7 & 24 & 18.6 & 2.4 & 200 & 54 & 3.8 & .07 \\
\hline 621 & do & 26.7 & 86.5 & 6.3 & & 16.5 & 2.2 & 78 & 31 & 2.4 & .08 \\
\hline 620 & Middle River & 40.6 & 232,6 & 6.7 & 97 & 50 & 1.9 & 465 & 81 & 5.7 & .07 \\
\hline 598 & _ _ do & 53 & 352 & 4.9 & 31 & 39 & 1.6 & 368 & 105 & 3.5 & .03 \\
\hline \multicolumn{12}{|c|}{ Streams in Devoniun sandstone areas } \\
\hline 641 & Ravine on Crawford Mtn. . . & 0.24 & 0.03 & $\ldots \ldots \ldots$ & 1300 & 87 & 2.2 & & 6.0 & & \\
\hline 642 & Tributary of East Dry Branch & .65 & .12 & 900 & 720 & 128 & 2.5 & 9 & 11 & 0.8 & 0.07 \\
\hline 612 & Old Soil Branch. & .8 & .35 & 360 & 370 & 76 & 2.6 & 52.5 & 25 & 2.1 & .08 \\
\hline $569 \mathrm{~B}$ & East Dry Branch $\ldots .$. & 1.2 & 1.00 & 400 & & 100 & 6.0 & & & & \\
\hline 643 & do & 2.8 & 3.2 & 235 & & 166 & 1.9 & 65 & 40 & 1.6 & .040 \\
\hline 585 & Stony Run & 2.4 & 1.2 & 330 & 420 & 100 & 1.9 & 147 & 35 & 4.2 & .12 \\
\hline 584 & Mines Run & 3.7 & 3.3 & 135 & 180 & 66 & 2.15 & 142 & 56 & 2.5 & .045 \\
\hline 587 & Skidmore Fork _. . . . & 5.1 & 6.6 & 105 & 109 & 77 & 2.5 & 153 & 44 & 3.5 & .08 \\
\hline 583 & Little River $\ldots \ldots$ & 6.9 & 15.8 & 129 & 4.0 & 80 & 1.7 & 625 & 137 & 4.5 & .033 \\
\hline 582 & North River . . . & 9.9 & 17.2 & 100 & 80 & 107 & 1.7 & 180 & 46 & 3.9 & .08 \\
\hline 586 & - do do _. & 18.5 & 65.8 & 67 & 43 & 130 & 1.7 & 423 & 112 & 3.8 & .033 \\
\hline \multicolumn{12}{|c|}{ Calfpasture Riner } \\
\hline 627 & & 2.4 & 1.4 & 200 & 90 & 63 & 2.0 & 40 & 35 & 1.6 & 0.045 \\
\hline 628 & 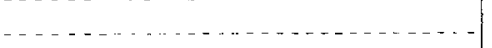 & 3.8 & 5.5 & 95 & 45 & 42 & 1.6 & 72 & 45 & 1.6 & .036 \\
\hline 629 & (1. & 5.5 & 12.4 & 40 & 58 & 57 & 1.7 & 118 & 63 & 1.9 & .030 \\
\hline 656 & - & 11.5 & 56.6 & 27 & 18 & 66 & 2.1 & 111 & 80 & 1.4 & .017 \\
\hline 662 & {$\left[\begin{array}{l}-\ldots \\
-\ldots-1\end{array}\right.$} & 14 & 77.1 & 34 & $\ldots$ & 70 & 1.9 & 279 & 111 & 2.5 & .023 \\
\hline 655 & $\ldots \ldots$ & 16.3 & 101.6 & 12.7 & $\ldots$ & 63 & 1.6 & 306 & 85 & 3.6 & .043 \\
\hline $654 \mathrm{C}$ & $\ldots \ldots \ldots$ & 24 & 126.8 & 11.4 & 18 & 53 & 1.4 & 93 & 120 & 1.2 & .01 \\
\hline $654 \mathrm{~B}$ & 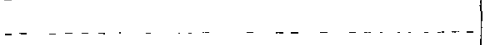 & 24 & 126.8 & 11.4 & 28 & 62 & 1.4 & 191 & 85 & 2.2 & .026 \\
\hline $654 \mathrm{~A}$ & {$[\ldots \ldots+1, \ldots$} & 24 & 126.8 & 11.4 & $\ldots$ & 75 & 1.6 & 295 & 106 & 2.8 & .026 \\
\hline 653 & 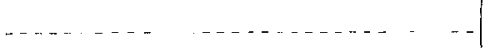 & 27.4 & 127.8 & 12.6 & 13 & 59 & 1.6 & 196 & 123 & 1.6 & .013 \\
\hline
\end{tabular}


Streams in alluvial terrace areas

\begin{tabular}{|c|c|c|c|c|c|c|c|c|c|c|c|}
\hline 610 & East Dry Branch & 4.8 & 5.5 & 57 & 34 & 80 & 2.1 & 389 & 55 & 7.1 & 0.13 \\
\hline 607 & - & 4.9 & 5.6 & 74 & 76 & 98 & 2.0 & 128 & 36 & 3.6 & .10 \\
\hline 608 & - & 5.6 & 7.06 & 74 & 76 & 62 & 1.6 & 137 & 39 & 3.5 & .09 \\
\hline 609 & _. _do & 6.2 & 7.2 & 67 & 48 & 60 & 1.6 & 110 & 31 & 3.5 & .11 \\
\hline 611 & $\ldots$ do $\ldots$ & 7.0 & 8.3 & 62 & 72 & 83 & 1.6 & 111 & 44 & 2.5 & .06 \\
\hline 614 & - do $_{2}$ & 7.9 & 8.7 & 67 & 47 & 69 & 1.7 & 126 & 75 & 1.7 & .023 \\
\hline 613 & Buffalo Branch & 8.9 & 23.1 & 50 & 14 & 62 & 1.9 & 56 & 44 & 1.3 & .03 \\
\hline 602 & North River & 19.3 & 66.4 & 54 & 47 & 110 & 2.0 & 287 & 76 & 3.8 & .05 \\
\hline 603 & $\ldots \mathrm{do}_{\ldots} \ldots$ & 21.0 & 68.1 & 40 & 55 & 95 & 1.5 & 346 & 102 & 3.4 & .033 \\
\hline 604 & $\ldots$ do $\ldots \ldots$ & 22.8 & 77.14 & 31 & 30 & 66 & 1.6 & 1301 & 180 & 7.2 & .04 \\
\hline 605 & $\ldots$ do $\ldots \ldots$ & 24.3 & 81.7 & 25 & 25 & 64 & 1.6 & 264 & 106 & 2.5 & .023 \\
\hline $606 \mathrm{~A}$ & ( & 25.6 & 83.6 & 21 & 10 & 48 & 1.7 & 190 & 80 & 2.4 & .03 \\
\hline $606 \mathrm{~B}$ & . do $\ldots . .$. & 28.1 & 101.8 & 16 & 12 & 42 & 4.2 & 375 & 127 & 2.9 & .023 \\
\hline
\end{tabular}

Tye River basin (granodiorite area)

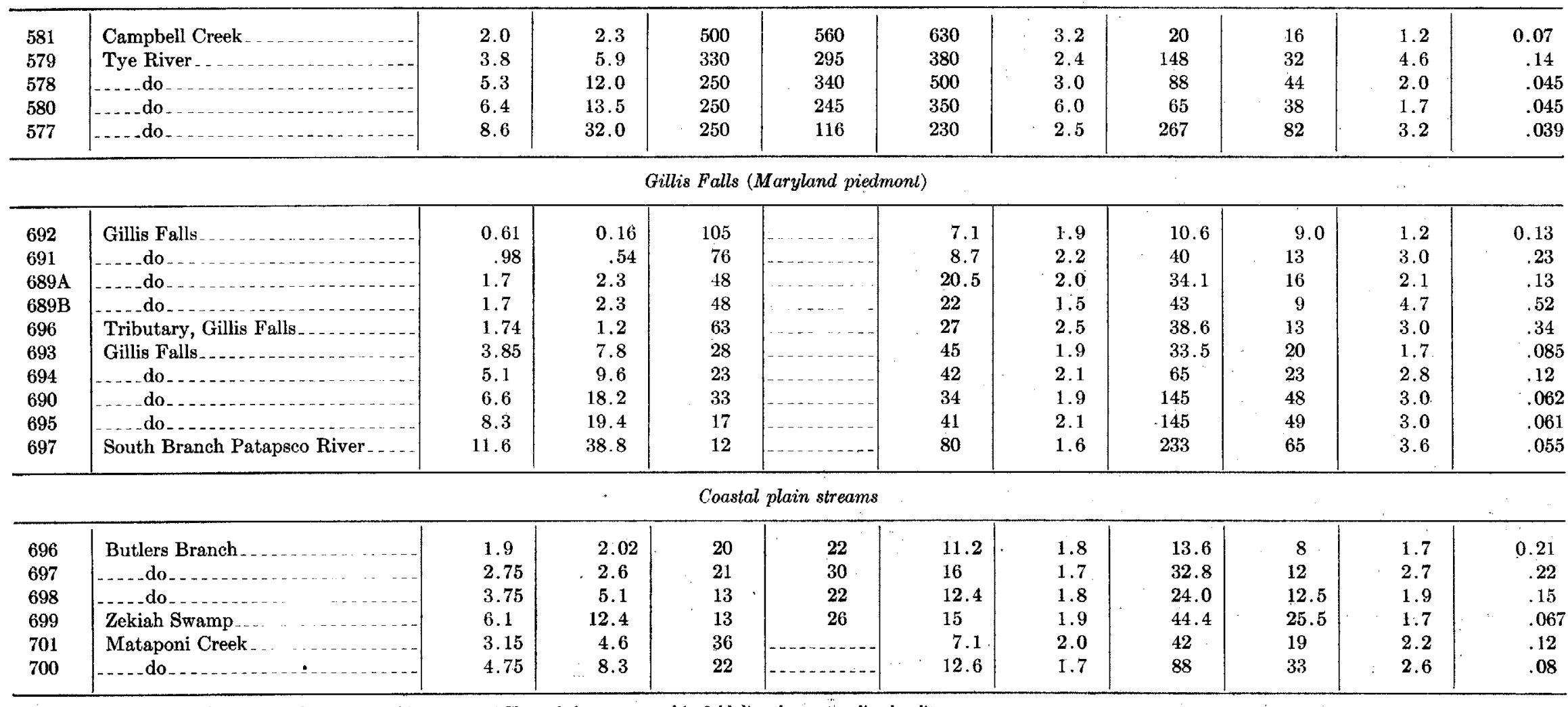

1 Channel slope at locality measured on topographic map. ${ }^{2}$ Channel slope measured in field direotly on sampling locality. 
much more rapidly and achieve a pronounced flattening at an earlier stage. Conversely, if two areas of different lithologic character have the same relief they must be of different age.

As has been thought by some, the regularity of the topography in the Central Appalachians and the Piedmont may simply be the result of the action of processes over a long period of time on rocks of different resistance to mechanical and chemical attack. The fact that these rocks are exposed in belts of regular thickness and attitude for great distances results in a regular topography of ridges and valleys. That the altitudes of the tops of many interstream ridges composed of similar rocks are nearly the same is only because the belts of rock have nearly the same width and the region has undergone erosion for so long that a condition of dynamic equilibrium has been reached. The height of a ridge underlain by sandstone, for example, must be correlative with the width of the outcrop belt, because given sufficient time, the stream profiles approach a uniform or nearly uniform shape, and the fall from the divide to the point where the streams leave the sandstone area is determined by the distance travelled. This concept was discussed more than a generation ago by N. S. Shaler (1899).

In larger, geologically complex areas, where streams flow through areas of different kinds of bedrock, the lithologic and topographic features of the headwater area must have an influence on the topographic form of the downstream area. This is because the stream must carry away the erosion products of the entire basin. If these are resistant to wear they determine the minimum channel slopes required to carry them off and therefore affect the rate of downcutting of the main river. Since this acts as a local baselevel for its tributaries it affects their profiles and hence the topographic form of the adjoining area.

We may expect, for example, if the conclusions presented here are correct, that a river carrying quartzite gravel through a limestone region or schist region erodes less rapidly than a river of comparable size that is carrying softer rock derived locally. The river with quartzite gravel acts as a more nearly stable baselevel for its tributaries and is bordered by a region of lower relief. Observations on streams in the Shenandoah valley actually confirm this hypothetical generalization. The Middle River, for example, has a higher proportion (50 percent or larger) of locally derived limestone on its bed than the neighboring North River, whose bed is predominantly sandstone derived from upstream. The Middle River is more deeply incised in the surrounding terrain and is bordered by a rougher terrain than is the North River. The North River has a relatively straight course and flows on a steeper gradient, whereas the Middle River has developed intricate meanders and joins the North River after a much greater distance of travel over slopes that, as a consequence of the greater length, are gentler.

\section{REFERENCES CITED}

Barrell, Joseph, 1925, Marine and terrestrial conglomerates: Geol. Soc. America Bull,, v. 36, p. 279-342.

Butts, Charles, 1933, Geologic map of the Appalachian Valley in Virginia: Va. Geol. Survey, scale 1:250,000.

1940, Geology of the Appalachian Valley in Virginia: Va. Geol. Survey Bull. 52, $568 \mathrm{p}$.

Carroll, Dorothy, Mineralogy of rocks, soils, and alluvial deposits of the Middle River basin, Augusta County, Va.: U. S. Geol. Survey Prof. Paper 314- (in preparation, 1957).

Davis, W. M., 1909, Geographical Essays: New York, Ginn and Co.

Edmundson, R. S., 1945, Industrial limestones and dolomites in Virginia; northern and central parts of Shenandoah Valley: Va. Geol. Survey Bull. 65, 195 p.

Gilbert, G. K., 1877, Report of the geology of the Henry Mountains: U. S. Geog. and Geol. Survey Rocky Mtn. Region, 160 p.

1914, The transportation of debris by running water: U. S. Geol. Survey Prof. Paper 86, 259 p.

Horton, R. E., 1945, Erosional development of streams and their drainage basins; hydrophysical approach to quantitative morphology: Geol. Soc. America Bull., v. 56, p. 275-370.

Jonas, A. I., 1928, Map of Carroll County showing the geological formations: Md. Geol. Survey, scale 1:62,500.

Jones, O. T., 1924, The Upper Towy drainage system: Geol. Soc. London Quart. Jour., v. 80, p. 568-609.

Langbein, W. B., and others, 1947, Topographic eharacteristics of drainage basins: U. S. Geol. Survey Water-Supply Paper 968-C, p. 125-157.

Leopold, L. B., and Maddock, T., 1953, The hydraulic geometry of stream channels and some physiographic implications: U. S. Geol. Survey Prof. Paper 252, 57 p.

Lipka, Joseph, 1918, Graphical and mechanical computation: John Wiley and Sons, Inc., New York, 259 p.

Matthes, G. H., 1947, Macroturbulence in natural stream flow: Am. Geophys. Union Trans, v. 28, no. 2, p. 255-261; discussion by F. E. Mathes, p. 262-266.

Pettijohn, F. J., 1949, Sedimentary rocks: New York, Harper and Brothers, $526 \mathrm{p}$.

Rubey, W. W., 1952, Geology and mineral resources of the Hardin and Brussels quadrangles (in Illinois): U. S. Geol. Survey Prof. Paper 218, $175 \mathrm{p}$.

Schoklitsch, Armin, 1933. ttber die Verkleinerung der Geschiebe in Flussläufen: Akad. Wiss. Wien Sitzungsber., Math-naturwiss. Klasse, Bd. 142, p. 343-366.

- 1936, Geschiebebewegung in Flüssen und an Stauwerken: Wien, Verlag von Julius Springer, $108 \mathrm{p}$.

Shaler, N. S., 1899, Spacing of rivers with reference to hypothesis of baselevelling: Geol. Soc. America Bull., v. 10, p. 263-276.

Shulits, S., 1941, Rational equation of river bed profile: Am. Geophys. Union Trans., 22nd Ann. Mtg., pt. 3, p. 622-630.

Wolman, M. G., 1954, A method of sampling coarse river-bed material: Am. Geophys. Union Trans., v. 35, p. 951-956.

1955, The natural channel of Brandywine Creek, Pa.: U. S. Geol. Survey Prof. Paper 271, 56 p.

Woodford, A. O., 1951, Stream gradients and Monterey Sea Valley: Geol. Soc. America Bull., v. 62, p. 799-852. 


\section{INDEX}

Abrasion of limestone in bed material

Acknowledgments.

Alluvial deposits, petrologic studies

Alluvial terrace areas, channel slopes.

description...

principal measurements of streams

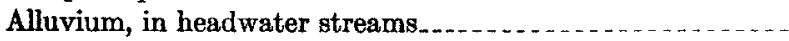

Analyses, grid, description of method

grid, Franks Mill reach

Area, definition

Areas studied, definition .

Athens limestone.......... 76,79

alluvium on ........ 86

Augusta County, Va......... 49

B

Bed material, changes in lithology with distance. ......... . lithologic composition at measurement localities......... movement of origin.

physical properties. sorting

Bedrock structure, as factor controlling particle size ..... $86-87$

Beekmantown limestone . . . .

Bifurcation ratio

Black Hills, S. Dak., length-drainage area relation ........ 64

Boulders, concentration near source. ..... 83

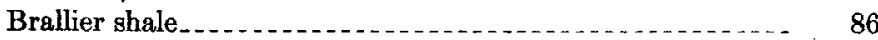

Brandy wine formation

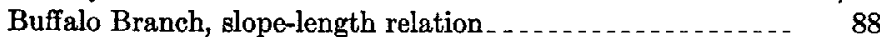

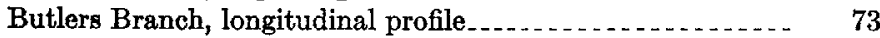

Butts, Charles, cited

\section{C}

Calfpasture River, Va., bed-material size _... _. _ _ _ 54-55 channel cross section . . . . . . . . . . . . . . longitudinal profile.............. 73 particle size in . . particle size-length relation $\ldots \ldots \ldots 8,72,73$ particle size slope relation $\ldots \ldots \ldots$

Calfpasture River basin, description lithologic composition of bed . . . . . . . . . . . . . . . 84 principal measurements of streams. . . . . . . . . . 92

Carroll County, Md..................... 49

Channel cross section definition . . . . . . measurements . . . . . . .

Channel slope, controlling factors . . . . . . . . . . . 53, 61, 62-63 relation to particle size.

Charles County, Md.

Chemical resistance, as factor controlling particle size . . . 87

Chert, in bed material, Franks Mill reach of Middle River _ . . 77, 87 in soils.

Christians Creek, Va., principal measurements used as example in discussion of length-area relation....

Coastal-plain streams in Maryland, channel cross sections... description longitudinal profile principal measurements. slope-length relation
CPage

Competence of streams, as related to profile $\ldots \ldots \ldots 9$

Conococheague limestone $\ldots \ldots \ldots \ldots .76,81 ; \mathrm{pl} .10 \mathrm{~A}$

Constant $k$, as index of competence

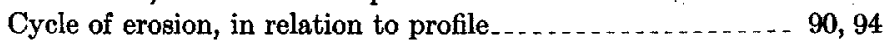

$\mathrm{D}$

Davis, W. M., cited.

Definitions of factors measured.

Depth of channel, definition

Depth, selation to drainage area

Depth-width ratio

$\begin{array}{ll}\text { Devonian sandstone areas, principal measurements of streams } & 92\end{array}$ relation of channel slope to cross section . . . . . . ....... 61 relation of particle size to length. ................ 68 relation of particle size to slope ........ 57 relation of slope to length

Discharge, related to drainage area................ 54

Drainage area, related to channel cross section . . . . . related to discharge . . . . . . . related to length $\ldots \ldots \ldots$. . related to slope $\ldots \ldots$

Drainage basins, analysis of comparability _._. $88-89$ shape................ 65

Drainage density, Horton's formula . . . .

E

East Dry Branch, Va., geologic conditions longitudinal profile... $88-89$ particle size in principal measurements. ratio of depth to width.......... 61 relation of length to drainage area $\ldots \ldots+65$ relation of particle size to lithologic composition _ _ _ . 74, 82-84 relation of profile to geologic features _. sandstone outerop_... $10 B$ slope-length relation

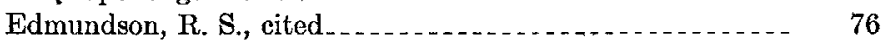

Eidson Creek, Va., limestone outcrop............... pl. 10A lithologic composition of bed material principal measurements...................... 91

Eidson Creek valley, geologic relations _... . . . . . . . . 81 longitudinal profile........................ 81

Ephemeral streams, in areas of residuum .............. 85-86

Equation, Horton's general formula................. 65 longitudinal profile........................ 70 relation of length to area, general formula $\ldots \ldots \ldots$ relation of slope, particle size, and length $\ldots$

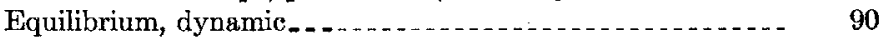
Erosion cycle, relation to longitudinal profile

F

Fall, definition relation to length and particle size (Eq. 14, 15) _...... 72,73

Franks Mill reach, Middle River, Va., geology of river bed 76 lithologic composition of bed materials_............. 76 relation of median size to lithologic composition ....... . 80-81 summary of conditions........................ $80-81$ 
Gaging stations, discharge measurements

Geologic conditions, Eidson Creek valley

Geologic controls, drainage area-slope relations length-drainage area relation.:

length-particle size relation

particle size.

slope-length relation

Geologically diverse areas, relation of slope to length $\ldots \ldots$. $87-88$

Geologically similar areas, relation of slope to length . . . . . . 8 87-88

Gilbert, G. K., cited ..................... 53,74 slope-discharge relation ........................ 47

Gillis Falls basin, Md., channel slopes . . . . . . . description . . .

lithologic composition of bed material $\ldots$

longitudinal profile $\ldots \ldots \ldots$.

principal measurements of streams . . . . . . . . . . . . . 93

relation of particle size to length $\ldots \ldots \ldots \ldots \ldots 6,69,72,73$

relation of particle size to lithologic composition _. . . . . 74, 85

relation of particle size to slope........

Granodiorite area, longitudinal profile $\ldots \ldots \ldots$ _. 88

principal measurements of streams _._.

relation of slope to length.

Grid analyses, Franks Mills reach of Middle River _... _ 76

Grid-sampling method .......... 48-49

$\mathbf{H}$

Horton, R. E., eited ............. 63

drainage network analysis . . _ . $\ldots 5,66$

application at Christians Creek, Va.

mathematical extension...................... 66

I

Initial size, as factor in controlling particle size

$\mathbf{J}$

Jones, O. T., cited

$\mathbf{L}$

Langbein, W. B., cited ................. 63

Lateral migration, as source of bed material _....... 79

Length, definition

general relation to drainage area

ratio . . . . . . . . .

relation to drainage area, mathematical discussion . . . . $65-69$

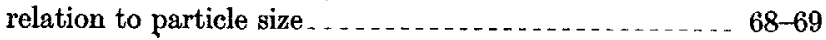

Lenior limestone.

Leopold, L. B., and Maddock, T, cited

Limestone and dolomite areas, principal measurements of streams

Limestone area, channel slopes....................... 54 relation of length to area

relation of slope to length $\ldots \ldots$

Limestone in bed material, Franks Mill reach of Middle

River........... 77-78, 87

Lipka, Joseph, cited........................... 70

Lithologic components of bed material, source, amount, size distance traveled..................... 76-78

Lithologic composition of bed material, Calfpasture River $\ldots$. 84-85 East Dry Branch. . . . . . . . . . . . . . . . . . . . . . 82-84

North River.

relation to particle size

84

74
Locality 590, Franks Mill reach, distribution of lithologic

components...............................

Page

Locality 592, Franks Mill reach, distribution of lithologic components

$74-80$

Longitudinal profile, controlling factors _ _ _ _ $63,87-90,94$

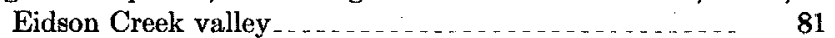

mathematical expression . . . . . . . . . . . . . . $69-74$

relation to particle size and length . . . . . . . . . . 71-74

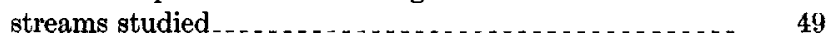

M

Martinsburg shale areas, alluvium in

channel slopes.

Horton's analysis _........

longitudinal profile $\ldots$

principal measurements of streams _.............. 92

relation of slope to length ............

$\begin{array}{ll}\text { Mass movement as source of bed material } & 82\end{array}$

Mataponi Creek, Md. _....... 53

Methods of study . . .

Methods, size-analysis grid $\ldots \ldots$

Middle River, Va., locality 615 , bed material at $\ldots \ldots \ldots \ldots 6$

longitudinal profile

particle size of bed material _.

principal measurements _._. _ _ _ _ _ _ _ _ 91,92

relation of particle size to lithologic composition $\ldots$. $74-84,87$

relation of profile to geologic features . . . . . . . . . . . $88-89$

See also Franks Mill reach.

Mingus Mountain quadrangle, Arizona, relation of length to

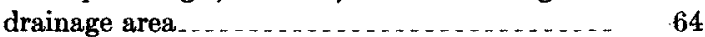

Mosheim limestone....... 74,76

\section{$N$}

Nelson County, Va. .................... 49,51

North River basin, Va, channel slopes.

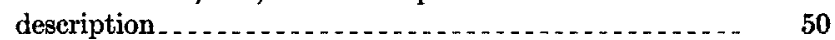

lithologic composition of bed materials

particle size of bed material _.......... 57

principal messurements _........... 91,92,93

relation of depth to width

relation of length to drainage area $\ldots \ldots \ldots+65$

relation of particle size to length

relation of particle size to slope

relation of slope to length

$\mathrm{O}$

Opequon Creek, Va., slope-length relation................

$\mathbf{P}$

Particle size, controlling factors $\ldots \ldots \ldots$. $86-87$

definition ...................... 48

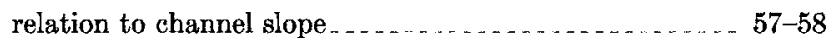

relation to composition . .

relation to length $\ldots$

testr.

relation to length and slope $\ldots \ldots \ldots 71,72$

relation to lithologic composition

relation to nature of valley

relation to slope and area ...... $58-60$

studies of . . . . .

Particle size and slope data, ephemeral streams . . . . . . . . 86

Patapsco River, South Branch. ..................... 52 
Pebble counts

method of determining particle size

East Dry Branch. . . . . . . . . . . . . . . . . . . . . .

Pettijohn, F. J., cited

Physical resistance, as factor controlling particle size $\ldots . . . .$.

Physiographic divisions principal measurements of streams..............

Plucking, evidence of source of bed material $\ldots \ldots \ldots \ldots \ldots$

Pools and riffles, bed material in .

Potomac River basin, relation of discharge to drainage area... studies of landform and geologic history ............

Prince Georges County, Md.

\section{$\mathrm{R}$}

Relief of region, as factor controlling particle size . . . . . . . . . Residuum in headwater areas.

Riffles, particle size at. plucking at, Franks Mill reach

Rubey, W. W., concept of adjusted channel cross section of streams

$\mathrm{S}$

Sandstone in bed material, Franks Mill reach. $76-77,87$

Schoklitsch, Armin, cited

Selective transpcrtation, East Dry Branch

Shale and limestone areas with quartite

relation $\ldots \ldots \ldots$

Shenandoah Valley, ephemeral streams $\ldots \ldots \ldots \ldots . . . . .85-86$

Shulits, S., cited . . . . . . . . . . . . 74

Size-distribution analysis, grid method........ 48,74

Slope, definition . . .

relation to area . . . . . 56,63

relation to length . . . . . $69,91-93$

relation to length and geology _........

relation to length and particle size (Eq. 13) . . . . . . 71, 72

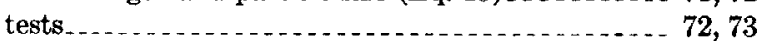

Page

Slope, relation to particle size $\ldots \ldots \ldots 5$ 55

relation to particle size-area ratio ......... 59

relation to profile. ............. $63-67$

Slope of stream channel, determining factors. $\ldots \ldots$

Soils of area, petrologic studies. . . . .

Solution of limestone in bed material 78

Sorting . . . .

Sorting characteristics, ephemeral streams . _......... 86

Staunton overthrust fault ................

Sternberg, theory cited .................

Stream-bed material, characteristics _... _ _. _ _ _ . . . . . 54-58

origin and composition

Symbols, definition $\ldots \ldots \ldots$

$\mathbf{T}$

'Tufa, in Franks Mill reach....................... 79

Tye River basin, Va., channel slopes................ 54

description ............... 48, 52

longitudinal profile . . . . . . .

principal measurements of streams . . . . . . . . . . . . 93

relation of particle size to length $\ldots \ldots \ldots \ldots \ldots, 72,73$

relation of particle size to slope . . . . . . . . . . . . . 57

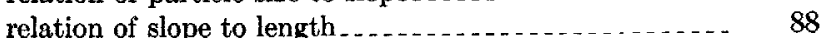

W

Width of channel, definition . . .

relation to drainage area.......................... 61

Wissahickon schist area, longitudinal profile ............ 88 relation of slope to length

Wolman, M. G., eited. ...... 90

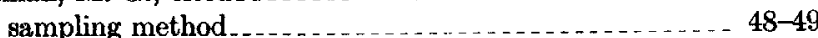

Woodford, A. O., cited $\ldots \ldots \ldots \ldots, 74$

Z

Zekiah Swamp, Md............... 49, 53

relation of particle size to length... . . . . . . . . . . . . 72, 73 